\title{
EDUCAÇÃO FÍSICA E CONHECIMENTO ESCOLAR DA QUINTA À OITAVA SÉRIES DO ENSINO FUNDAMENTAL
}

DENISE FERRAZ LIMA VERONEZI

Dissertação apresentada à Escola de Educação Física e Esporte da Universidade de São Paulo, como requisito parcial para obtenção do grau de Mestre em Educação Física.

ORIENTADOR: PROF. DR. JOSÉ GUILMAR MARIZ DE OLIVEIRA 
Veronezi, Denise Ferraz Lima

Educação física e conhecimento escolar da quinta à oitava séries do ensino fundamental / Denise Ferraz Lima Veronezi. -- São

Paulo : [s.n.], 1999.

$\mathrm{x}, 110 \mathrm{p}$.

Dissertação (Mestrado) - Escola de Educação Física e Esporte da Universidade de São Paulo.

Orientador: Prof.Dr. José Guilmar Mariz de Oliveira.

1. Educação física escolar 2. Ensino fundamental I. Título. 


\section{AGRADECIMENTOS}

Ao Professor Doutor José Guilmar Mariz de Oliveira pela atenção, paciência, incentivo e dedicação na orientação deste trabalho e pela sua contribuição na minha formação profissional.

Às professoras Doutoras Circe Maria Fernandes Bittencourt e Sheila Aparecida dos Santos Silva, pelas orientações, críticas e contribuições a este trabalho.

Aos professores Doutores Nilson José Machado e Ana Cristina Arantes, pela participação no processo de qualificação e defesa da dissertação.

À Diretoria Regional de Ensino Leste IV, à Dirigente Regional de Ensino Nereida Maria Núcci e aos Professores de Educação Física que participaram da pesquisa de campo realizada.

À Liliana Ferraz L. Gallucci, pela dedicação, orientações e, principalmente, por sua amizade e carinho na realização deste trabalho.

À Mariângela F. Lima, pelo apoio constante durante toda a caminhada pelo programa de mestrado.

Aos meus queridos pais, que possibilitaram com esforço e dedicação que eu pudesse ter uma formação profissional.

Ao meu marido Pedro, Ao meu filho Fábio. 


\section{SUMÁRIO}

Página

LISTA DE TABELAS.................................................................. v

LISTA DE ANEXOS............................................................... vi





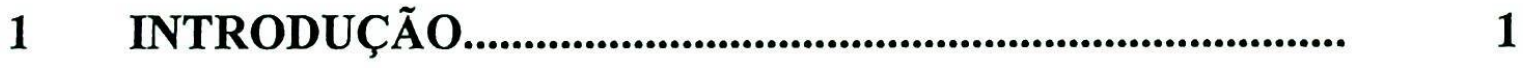

2 CONSIDERAÇÕES TEÓRICAS.............................................. 9

2.1 Relações entre: educação, conhecimento, conhecimento escolar, aprendizagem e desenvolvimento...............................

2.2 Aspectos do aluno da quinta à oitava séries do ensino fundamental.

2.3 Educação, educação física da quinta à oitava séries do ensino fundamental.

2.4 O componente curricular educação física e o conhecimento escolar.............................................................................

$3 \quad$ METODOLOGIA......................................................................... 57

4 ANÁLISE DA BIBLIOGRAFIA....................................... 71 
4.1 Educação de corpo inteiro: teoria e prática da educação física........................................................................................................

4.2 Regras oficiais de voleibol e regras oficiais de basquetebol...........................................................................................

4.3 Parâmetros curriculares nacionais: educação física da $5^{*}$ à $8^{2}$ séries do ensino fundamental..............................................

4.4 Aulas de educação física: $1^{\circ}$ grau............................................. 85

5 CONSIDERAÇÕES FINAIS..................................................... 90

REFERÊNCIAS BIBLIOGRÁFICAS..................................... 98

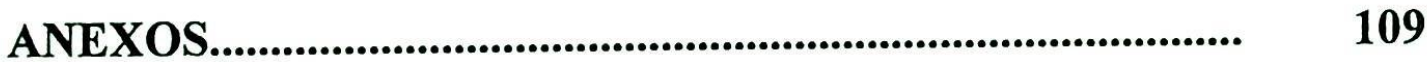




\section{LISTA DE TABELAS}

\section{Página}

TABELA 1- Distribuição do número de professores entrevistados segundo sexo e tempo de graduação.

TABELA 2- Distribuição do número de professores entrevistados segundo a região da instituição de ensino superior de origem..................

TABELA 3- Distribuição do número de professores entrevistados segundo a leitura dos PCNs e tempo de graduação

TABELA 4- Distribuição do número de professores entrevistados segundo a utilização de referência bibliográfica e tempo de graduação. 


\section{LISTA DE ANEXOS}

Página

ANEXO I- Relação das 26 escolas selecionadas... 


\title{
RESUMO
}

\section{EDUCAÇÃO FÍSICA E CONHECIMENTO ESCOLAR DA QUINTA À OITAVA SÉRIES DO ENSINO FUNDAMENTAL}

\author{
Autora: DENISE FERRAZ LIMA VERONEZI \\ Orientador: PROF. DR. JOSÉ GUILMAR MARIZ DE OLIVEIRA
}

A Educação Física, no âmbito da educação escolar básica, encontra-se inserida num contexto peculiar do processo de ensino e aprendizagem, cujas características são: sistematização, organização curricular, seqüencialidade, e intencionalidade. Entende-se que, como resultante desse processo, o conhecimento escolar apresenta-se com características específicas, considerado em relação a conteúdos de natureza conceitual, procedimental e atitudinal. Este estudo foi desenvolvido com o objetivo pertinente à identificação, descrição e análise dos tipos de conhecimento preconizados para efeito de sistematização do saber escolar, relacionados com o ensino e a aprendizagem da Educação Física na quinta, sexta, sétima e oitava séries do ensino fundamental. Os dados necessários, obtidos de referências bibliográficas específicas, selecionadas da indicação feita por 26 professores de Educação Física atuantes nas referidas séries, de escolas públicas estaduais vinculadas à Diretoria Regional de Ensino Leste IV, na cidade de São Paulo, foram tratados por meio de análise de conteúdo. Os resultados permitiram inferir que a maioria dos professores 
envolvidos não utiliza qualquer referencial bibliográfico para o planejamento de suas aulas, baseando-se em rotinas pessoais, com ênfase em conteúdos relacionados com modalidades esportivas, conseqüentes, exclusivamente de suas experiências docentes. Nas quatro únicas obras selecionadas foram encontradas referências a conhecimentos de natureza conceitual, procedimental e atitudinal, embora nem sempre específicos, sistematizados e com uniformidade de objetivos.

Palavras-chave: Educação física; Conhecimento escolar; Ensino fundamental. 


\begin{abstract} PHYSICAL EDUCATION AND SCHOLASTIC KNOWLEDGE FROM
LEVEL FIVE TO LEVEL EIGHT OF MIDDLE SCHOOL
\end{abstract}

\author{
Author: DENISE FERRAZ LIMA VERONEZI \\ Adviser: PROF. DR. JOSÉ GUILMAR MARIZ DE OLIVEIRA
}

Physical education, in the realm of basic school education, has found itself inserted in a peculiar context of the teaching and learning process, whose characteristics are: systematization, curricular organization, sequency and intentionality. It is understood that, as a result of this process, scholastic knowledge has presented itself with specific characteristics, considered in relation to contents of conceptual, procedural and attitudinal nature. This study was developed with the objective pertaining to the identification, description and analysis of the knowledge types, recommended for purpose of systematization of scholastic knowledge, related to physical education teaching and learning from level 5 to level 8 of middle school. The necessary data, obtained from specific bibliographical references, selected from the indication made by 26 physical education teachers of the pertaining grades, from state public schools bound to the East IV Regional Teaching Directory, in the city of São Paulo, were treated by means of content analysis. The results made it possible to infer that the majority of the interviewed teachers does not utilize any bibliographical reference to the planning of their classes and that they base themselves on 
personal routines, emphasizing contents related to sport modalities, mainly as a consequence of their teaching experiences. References to knowledge of conceptual, procedimental and attitudinal nature were found in the only four selected bibliographical materials, although seldom especific, systematized and with uniformity of objectives.

Key-words: Physical education; Scholastic knowledge; Middle school. 


\section{INTRODUÇÃO}

O componente curricular Educação Física, inserido no contexto escolar, faz parte de um universo mais amplo que é a educação. Para SAVIANI (1997, p.15), a educação "é um fenômeno próprio dos seres humanos". Segundo PILETTI (1996, p.17), “a educação é um processo universal do qual ninguém escapa, mas que varia de acordo com a sociedade em que se realiza". Em COLL (1996, p.41-2), a educação designa "o conjunto de atividades mediante as quais um grupo assegura que seus membros adquiram a experiência social historicamente acumulada e culturalmente organizada".

A palavra educação traz em si uma dupla conotação. Derivada do latim "educare", significa "criar, alimentar" ou "educere", que significa "conduzir", e, dependendo da concepção, haverá ações distintas sobre o ser humano (SILVA, 1991). Assim, a conotação da educação como aquela que "alimenta", associa-se à idéia de armazenar informações no indivíduo. No entanto, a conotação de educação como "conduzir", aproxima-se da idéia de descobrir as potencialidades do indivíduo.

A educação resulta de um amplo espectro de atividades humanas institucionalizadas, ou não. Desse modo, a educação escolar não é a única atividade educativa existente, pois há outras, tais como a família, a igreja, os meios de comunicação etc., consideradas por PILLETTI (1996) como educação informal. Assim, "ninguém escapa da educação. Em casa, na rua, na igreja ou na escola, de um modo ou de muitos, todos nós envolvemos pedaços da vida com ela" (BRANDÃO, 1981, p.7). 
A educação escolar possui características que the são peculiares, tais como: a sistematização do conhecimento, a intencionalidade, a organização curricular e a estruturação de disciplinas ou componentes curriculares. A escola transmite apenas uma parcela da experiência humana, acumulada ao longo do tempo, onde ensinar e aprender supõem esforços e sacrificios de toda natureza (FORQUIN, 1993).

Partindo do ponto que a escola é uma instituição social, que veicula saber, conhecimento e onde se espera que ocorram ensino e aprendizagem (SAVIANI, 1994), os componentes que fazem parte do currículo escolar deveriam contribuir para que este conhecimento seja disseminado nos diferentes níveis da educação escolar. Entretanto, o que ensinar, que conteúdos transmitir e o que se aprende, ou seja, os aspectos cognitivos, são tão importantes quanto a maneira utilizada para ensinar e adquirir conhecimentos. Contudo, a escola tem enfatizado mais o produto do que o processo (BLANCO, 1995).

O significado de ensinar relaciona-se com "instruir, fazer saber, comunicar conhecimentos ou habilidades, mostrar, guiar, orientar, dirigir". Aprender significa "buscar informações, rever a própria experiência, adquirir habilidades, adaptar-se às mudanças, descobrir significados nos seres, fatos e conhecimentos, modificar atitudes e comportamentos" (ABREU \& MASETTO, 1990, p.5-6). Nesses termos, quando se fala em escola, está implícita a concepção de que alguém ensina algo e isto é denominado como "saber escolar" (SAVIANI, 1997), "cultura escolar" (DOMINIQUE, 1993) e "conhecimento ensinável" (FORQUIN, 1992).

O conhecimento escolar é um tipo específico de conhecimento que se distingue de outros (SANTOS, 1994), por apresentar saberes, hábitos, critérios de excelência, currículo oculto, sistemas de valores, no qual é transformado, 
recontextualizado até chegar à escola (CHERVEL, 1990; FORQUIN, 1993; SAVIANI, 1994). No entanto, a seleção de conteúdos a serem utilizados na escola não constitui uma tarefa fácil, pois há influências políticas que não podemos negligenciar e, também, as chamadas ciências de referência, conforme destaca APPLE (1982), FORQUIN (1992), DOMINIQUE (1993), MOREIRA (1994), SANTOS (1994), BELTRAME (1995) e SAVIANI (1997).

Durante a elaboração do currículo, é necessário levar-se em conta os objetivos educativos de ciclo e de área (TYLER, 1976), assim como informações sobre o ato de ensinar, quando e como ensinar, incluindo-se os procedimentos, princípios, conceitos, fatos, atitudes, normas e valores como conteúdos de ensino e aprendizagem (COLL, 1996). Para FORQUIN (1993), a transmissão que ocorre na educação relaciona-se a conhecimentos, competências, crenças, hábitos e valores. Segundo SAVIANI (1997), os elementos envolvidos no saber escolar são: valores, atitudes, hábitos, símbolos e conceitos.

A organização curricular apresenta, como uma de suas características, a estruturação de disciplinas que possuem "fronteiras" nítidas (FORQUIN, 1992). As disciplinas apresentam autonomia e história próprias e constituem um conjunto de conhecimentos ordenados cuja finalidade é a educação escolar (SAVIANI, 1994). Entretanto, a natureza do conhecimento humano não é subdividida, mas, sim, faz parte das contingências sócioculturais. Conforme assinala CHAUÍ (1995), ao fazer referência ao conhecimento da humanidade, a idéia, proveniente da antigüidade grega, quando a filosofia é vista como a totalidade de saberes, foi desaparecendo com o tempo. Assim, ciência e filosofia foram, aos poucos, distanciando-se e diferentes ramos foram surgindo. Deste modo, "a seleção cultural escolar" e as diferentes disciplinas têm influências da sociedade, portanto, da cultura na qual se insere. 
O propósito de qualquer programa educacional consiste em promover a aprendizagem, ou seja, o ensinar e o aprender são elementos constitutivos do processo educacional (GAGNÉ, 1980). No entanto, dependendo da concepção que se tenha sobre desenvolvimento e aprendizagem, diferentes ações educacionais serão implementadas, uma vez que "o conceito de aprender determina o de ensinar, porque ambos constituem uma relação inseparável" (BLANCO, 1995, p.312). Para PLAGET (1973), o desenvolvimento segue o seu curso por meio de um processo de estágios independente da aprendizagem. Assim, para não "pular" etapas da aprendizagem, deve-se esperar que a criança esteja pronta para recebê-la. Em VYGOTSKY (1994), há a utilização do conceito de zona de desenvolvimento proximal, segundo o qual o aprendizado eficaz é aquele que se adianta ao desenvolvimento, provocando mudanças internas que trabalham com o nível do desenvolvimento potencial do aluno e não somente o seu desenvolvimento real.

Em nosso país, a educação básica é subdividida em: educação infantil, ensino fundamental e ensino médio (BRASIL, 1998a). Nesse contexto, encontrase o componente curricular Educação Física, previsto na atual Lei de Diretrizes e Bases da Educação Nacional (LDB) que considera que "a educação física, integrada à proposta pedagógica da escola, é componente curricular da educação básica, ajustando-se às faixas etárias e às condições da população escolar sendo facultativa nos cursos noturnos" (art. 26, parágrafo $3^{\circ}, 1998$ a). Nos atuais PCNs (Parâmetros Curriculares Nacionais) de quinta à oitava séries em Educação Física, é enfatizado o princípio da inclusão dos alunos, revertendo-se o quadro histórico da área de excluir os menos aptos e o princípio da diversidade, no sentido da compreensão do aluno em suas diversas dimensões. 
Sendo assim, as atividades de Educação Física estão inseridas na escola e, para implementá-las como componente curricular, é necessário “(...) preservar, manter e aprofundar a sua especificidade na escola" (SOARES, 1996, p.7). Assim, vários estudos apontam para a necessidade do conhecimento em Educação Física escolar ir além do saber fazer ou da prática, conforme ressaltaram MARIZ DE OLIVEIRA (1991), TANI (1991), De SANTO (1993), BETTI (1997) e BRASIL (1998c).

CISNEIROS (1995) enfatiza o caráter de "atividade" atribuído ao componente curricular Educação Física presentes também nos trabalhos de: CASTELLANI FILHO (1988), SOARES (1988), BRACHT (1989), MARIZ DE OLIVEIRA (1991) e REIS (1993). Na visão da autora, esse componente curricular assume o caráter de atividade nas séries iniciais do ensino de primeiro grau, ou atual ensino fundamental, assumindo o caráter de área de estudo ou disciplina nas subsequentes séries, de modo que o aluno assimila conhecimentos sobre o movimento humano e suas implicações "biológicas, psicológicas, ecológicas e socioculturais" (CISNEIROS, 1995, p.37).

Não podemos negar que o conhecimento em Educação Física escolar tem sido construído historicamente e, portanto, faz parte da própria evolução na qual se encontra a área. Sobre este aspecto SILVA (1996, p.30) salienta que :

Via de regra o ser humano dá especial destaque às pedras do caminho e não verifica o quanto já percorreu na sua longa estrada em direção aos objetivos desejados. Tendemos a supervalorizar o que ainda não foi feito e menosprezamos aquilo que já conseguimos fazer. Nossas atitudes no mundo são pautadas por nosso modo de olhar.

Nessa perspectiva, a questão que orientará o presente estudo consiste em discutir se esse componente curricular atende às categorias do conhecimento 
escolar, ou seja, há inseridos nele, conhecimentos do tipo: procedimentos, princípios, conceitos, fatos, atitudes, normas e valores? Neste sentido, o objetivo deste estudo será o de verificar se as categorias do conhecimento escolar estão presentes na literatura pedagógica em Educação Física, da quinta à oitava séries do ensino fundamental, entendendo, por literatura pedagógica da Educação Física todo material bibliográfico disponível, textos escritos, tais como: a) artigos publicados em periódicos científicos; b) livros; c) anais; d) teses e e) documentos oficiais, elaborados pelo poder público estadual, federal ou municipal.

Na nossa prática pedagógica, o ensino da Educação Física despertava importantes inquietações. A realização do planejamento escolar sempre provocou dúvidas, uma vez que não era possível encontrar, claramente, na literatura, princípios sobre o que ensinar e o que deve ser aprendido a partir desse componente curricular, sem que houvesse dúvidas sobre o seu dimensionamento, ou seja, a escolha dos conteúdos e o processo de avaliação. O interesse pela Educação Física escolar na presente pesquisa não foi por acaso, mas, sim, fruto de nossa atuação como professora na rede estadual de ensino fundamental na zona leste da cidade de São Paulo e, ainda, no terceiro grau em duas instituições. A interação entre essas experiências permitiu que vivenciássemos a problemática do ensino-aprendizagem em Educação Física escolar.

$\times$ A motivação pelo ensino fundamental, especificamente da quinta à oitava séries, não ocorreu por acaso, mas a partir da convivência diária com essas séries. Por meio desta convivência, pudemos verificar que, para as crianças da rede estadual de ensino, a quinta série representa um marco na educação escolar, um período de transição, de mudanças, ou seja, os alunos vinham de um processo no qual a figura do "professor da classe", como é denominado nas escolas, era, em sua grande maioria, o único professor. A partir da quinta série, os alunos 
passam a ter diferentes professores, com variados componentes curriculares. Essa fase despertou nossa atenção para a singularidade que representa este momento de passagem para a adolescência, como um período de mudanças físicas e psicológicas, com aumento de responsabilidade e também de liberdade. Notamos o grau de ansiedade dos alunos frente às aulas e o quanto eles apreciavam estes momentos. Conversando com eles, notamos que a maioria nunca tivera aulas de Educação Física, pois "o professor da classe” utilizava esse espaço ora para dar continuidade aos conteúdos que desenvolvia; ora para recreação, levando em conta, antes o bom comportamento geral da classe, o que tornava, muitas vezes, ainda mais reduzidos estes momentos. Foi possível, assim, constatar, que, para grande parte dos alunos da quinta série, tratava-se de uma primeira oportunidade de ter contato com aulas de Educação Física e cremos que residia aí nosso interesse, uma vez que eles se mostravam motivados e livres de preconceitos.

Deste modo, a partir da análise de resumos de teses e dissertações, verificamos a carência de pesquisas, especificamente, voltadas para a quinta à oitava séries do ensino fundamental em educação física escolar, ressaltando-se ainda que para SANTOS (1994), na educação, de maneira geral, faltam trabalhos sobre o que realmente consiste o conhecimento escolar.

Diante das considerações anteriormente realizadas, a metodologia apresentou características exploratórias, identificativas e descritivas. Articulado com entrevistas e análise de conteúdo de bibliografia específica. Para a composição da amostra, a opção escolhida consistiu em entrevistar professores que atuam na quinta à oitava séries do ensino fundamental em Educação Física. A escolha pelas escolas estaduais pertencentes à Oitava Delegacia de Ensino, atual Diretoria Regional de Ensino Leste IV, situada na zona Leste da cidade de São Paulo, não é ocasional, tal escolha está vinculada à nossa atuação como 
professora de Educação Física nessa região e, principalmente, por nos sentirmos inseridas naquela realidade local.

Este recorte da realidade escolar compõe-se de 27 escolas estaduais que oferecem as séries do ensino fundamental escolhidas para nossa pesquisa. Para as entrevistas, selecionamos, ao acaso, um professor de Educação Física de cada escola. Após as entrevistas, ou seja, tendo selecionado a referência bibliográfica em Educação Física escolar mais utilizada por estes professores, utilizamos a técnica da análise de conteúdos para verificarmos se as categorias do conhecimento escolar estão presentes, ou seja, se há conhecimentos do tipo: procedimentos, princípios, conceitos, fatos, atitudes, normas e valores, presentes na fundamentação teórica.

Esperamos com esta pesquisa trazer contribuições para o avanço das discussões na compreensão sobre o conhecimento escolar em Educação Física da quinta à oitava séries. Neste sentido, além da questão central das entrevistas, presente na metodologia, outras questões também foram solicitadas para compor as características sociodemográficas deste recorte escolar.

Nessa perspectiva, o capítulo denominado Considerações Teóricas é constituído por tópicos no sentido de buscar fundamentos para a compreensão do fenômeno investigado, os quais são apresentados da seguinte forma:

No tópico 1- Relações entre: educação, conhecimento, conhecimento escolar, aprendizagem e desenvolvimento - neste tópico estão reunidos alguns autores que discutem educação, conhecimento, escola, conhecimento escolar, saber escolar, cultura escolar, disciplina, aprendizagem e desenvolvimento.

No tópico 2- Aspectos do aluno da quinta à oitava séries do ensino fundamental - aqui estão presentes algumas discussões sobre a puberdade, o pré- 
adolescente e o adolescente; as manifestações culturais dos jovens e a escola, a construção de projetos e de identidades nesta fase da vida.

No tópico 3- Educação, educação física da quinta à oitava séries do ensino fundamental - procuramos, neste momento, mediante um breve retorno histórico, compreender as origens da quinta à oitava séries do ensino fundamental no contexto escolar e as relações da Educação Física no âmbito escolar.

No tópico 4- $O$ componente curricular educação física e 0 conhecimento escolar - no qual procuramos dimensionar a Educação Física no interior da instituição escolar e o conhecimento veiculado por este componente curricular.

Segue-se o capítulo 3 no qual descrevemos a metodologia. A seguir o capítulo 4 contendo a análise das obras mencionadas pelos entrevistados e, concluímos o trabalho, com o capítulo 5, no qual tecemos as considerações finais.

2.1 Relações entre: educação, conhecimento, conhecimento escolar, aprendizagem e desenvolvimento

No sentido de fundamentar a compreensão sobre educação, conhecimento, escola, conhecimento escolar, saber escolar, cultura escolar, disciplina ou componente curricular, currículo, inteligência e aprendizagem, buscamos, na literatura pertinente, autores que levantam esta discussão. A seleção dos mesmos ocorreu a partir de nossa própria história pessoal e trajetória profissional e dos conhecimentos adquiridos no programa de mestrado. Para FURLAN (1997, p.119): 
$\mathrm{O}$ autor do texto é o homem historicamente situado, que vive a experiência no mundo com os homens, que participa do existir num tempo e num espaço específicos a partir de determinadas condições econômicas, políticas, ideológicas e culturais (...). O texto, a obra, é a expressão do viver, experienciar, participar; é o produto colocado no mundo, tem a marca humana.

Segundo SAVIANI (1997), a educação como um fenômeno inerente à natureza humana varia em cada sociedade, nos diferentes grupos sociais, nos homens, de acordo com as concepções que se tenha de mundo. Assim, a educação é um processo histórico e dinâmico (PILETTI, 1996). Segundo COLL (1996, p.154), a educação designa:

Um conjunto de práticas mediante as quais o grupo social promove o crescimento dos seus membros, isto é, ajuda-os a assimilar a experiência historicamente acumulada e culturalmente organizada, a fim de que possam converter-se em membros ativos do grupo e agentes de mudança e criação cultural.

Neste amplo universo, a educação "não se reduz ao ensino, é certo, entretanto, que ensino é educação e, como tal, participa da natureza própria do fenômeno educativo" (SAVIANI, 1997, p.16). Em suma, a educação familiar, extra-escolar, os meios de comunicação entre outros, fazem parte da educação (COLL, 1996), os quais são considerados por PILETTI (1996) como educação informal, ou seja, não há um processo sistemático e intencional, enquanto o ensino escolar é desenvolvido formalmente na relação professor-estudantes, distinto de "quando o pai ensina ao seu filho alguma teoria que ele próprio desenvolveu; quando o índio ensina segredos das plantas e assim por diante, a isto chamamos de ensino não formal" (FLORES, 1986, p.37). Entretanto, nas variadas formas de educação, e concepções de educação como aquela que "alimenta", ou que 
"conduz" (SILVA, 1991), estão presentes a concepção de conhecimento, de saber.

De um modo geral, na forma de pensar de TUNG-SUN (1977), há dois tipos de conhecimento: o perceptivo e o conceitual. Em princípio, tal separação atende a necessidades didáticas mais a título de análise, uma vez que o conhecimento não existe isoladamente, tendo em vista a presença de elementos de um no outro e vice-versa. Pensar sobre filosofia do conhecimento e, em particular, tipos de conhecimento e conhecimento na escola, requer posicionamento filosófico. É tarefa complexa. O conhecimento para LUCKESI $(1990$, p.55) é analisado como uma maneira de interpretar a realidade, visando elucidá-la, ou seja, "desvelá-la, compreendê-la, torná-la inteligivel; em síntese, encontrar a verdade". Em GARCIA (1988, p.67), o significado de "conhecer" apresenta-se como:

Descrever um fenômeno, sejam em suas particularidades estruturais, seja em seus aspectos funcionais; prever a possibilidade de ocorrência futura de um evento (ou relatar um outro evento passado); e, por fim, manipular e utilizar, adequadamente, um objeto qualquer, além de reproduzi-lo, alterando até, as suas características básicas. Descrever ou manejar, eis a síntese do saber; daquele conhecimento que não conseguimos traduzir em palavras.

Na história Ocidental, a preocupação com o conhecimento é antiga, conforme afirma MATALLO JUNIOR (1997, p.13)," "praticamente todos os povos da antiguiidade desenvolveram formas diversas de saber”. Desde os filósofos présocráticos, haviam indagações sobre a possibilidade do conhecimento. Contudo, é a partir do filósofo grego Sócrates, que os problemas do conhecimento tomam mais impulso, principalmente com a busca do conhecimento verdadeiro (CHAUÍ, 1995), e do auto-conhecimento, explicitado no clássico pensamento socrático: 
“conhece-te a ti mesmo" (MACHADO, 1997). No século XVII, com o filósofo Descartes, a procura pelo conhecimento que não trouxesse nenhum motivo de dúvidas é levada ao extremo. O modo de pensar de Descartes, o encadeamento lógico do seu raciocínio, influenciou o povo ocidental de maneira que, para MACHADO (1995, p.30), a organização da escola, tal como se apresenta, com niveis de seriação, linearidade, hierarquia e pré-requisitos, é conseqüência do pensamento do filósofo, destacando que:

(...) A partir de Descartes, a idéia de cadeia tornou-se dominante na representação do conhecimento. Nas cadeias cartesianas, os elos deveriam ser construídos linear e paulatinamente ordenados por uma bem definida hierarquia que conduziria do mais simples ao mais complexo, não se hesitando em delimitar com nitidez critérios de simplicidade-complexidade. É possível reconhecer ainda hoje a situação hegemônica de tal concepção.

A ação docente apresenta articulação com discursos pedagógicos tributários de uma concepção de conhecimento, ou seja, as diferentes possibilidades do ser humano captar o real e a verdade caracterizam-se por tendências filosóficas diversas, tais como: dogmatismo, ceticismo, realismo, idealismo, positivismo, entre outras (LUCKESI, 1990). Na concepção de conhecimento, segundo MACHADO (1995), há a utilização da metáfora da "rede", na qual o conhecer, nesta percepção, é "conhecer o significado" (p.8). De modo que, pensar a escola no conhecimento enquanto "rede", significa mudar, reestruturar, afirmando que "neste terreno, quase tudo ainda está por ser realizado" (p.155). Nessa perspectiva, os componentes curriculares continuam a contribuir com suas especificidades, explicando que "de modo algum a concepção do conhecimento como uma rede de significações implica a eliminação ou mesmo a diminuição da importância das disciplinas" (p.192). As relações, as articulações 
em teias e nós de significados e nas ligações entre as interfaces nessa concepção de conhecimento, consiste que "todo conhecimento reside na articulação dos suportes, na arquitetura da rede, no agenciamento das interfaces" (LÉVY, 1998, p.184).

Ao longo do tempo, as relações entre conhecimento e trabalho foram sofrendo modificações. $\mathrm{Na}$ Antigüidade Grega, por exemplo, segundo MACHADO (1997), havia distinções entre conhecimento e trabalho. A noção de trabalho, que cabia aos escravos, não se associava ao conhecimento, mas, sim, à prática, distinta da concepção atual na qual o conhecimento está a serviço do trabalho. De fato, a aproximação decisiva entre mundo do trabalho e do conhecimento ocorreu a partir da Revolução Industrial, quando a informação passou a ser considerada mercadoria. Essas mudanças nas relações entre conhecimento e trabalho têm trazido conseqüências para o mercado de trabalho e, também, para o sistema educacional, cujos indícios podem ser percebidos:

Essa crescente identificação do mundo do conhecimento com o mundo do trabalho tem conduzido a transformações no significado do trabalho para as quais os educadores, nos diversos níveis de escolarização e nos diversos espaços do conhecimento ainda não parecem ter dedicado suficiente atenção. Um sintoma dessa falta de sintonia, no caso do ensino superior, pode ser observado na crise mundial do desemprego estrutural. (MACHADO, 1997, p.16).

Diante do crescente nível de informações que são geradas - sendo impossível o acesso a todo conhecimento produzido - à escola, cabe redefinir seu papel e contribuir para que os alunos "aprendam a aprender", que sejam capazes de analisar o que sabem, bem como onde obter as informações necessárias (MARCHESI \& MARTÍN,1995). Assim, para o próximo milênio, segundo FERNANDES $(1999$, p.22) a educação deverá se preocupar em formar um 
indivíduo que "aprenda a conhecer, a fazer, a conviver e a ser"; levando-se também em consideração, a "criatividade, a autonomia, e a capacidade de solucionar problemas". Diante desta realidade, TAJRA (1999) afirma que muitas escolas já estão preocupadas com esses novos paradigmas, os quais exigem "um indivíduo flexível e receptivo às mudanças e inovações" (p.12) e que também privilegiem valores como "participação, cooperação, comunicação, criatividade e pesquisa" (p.22). Para ZABALA (1997), as escolas têm enfatizado mais as capacidades cognitivas em detrimento de outras capacidades do ser humano, no entanto, afirma que, para um ensino que se propõe a formar o indivíduo integralmente, os conteúdos deveriam apresentar-se equilibrados, pois todo conteúdo, por mais específico que seja, é adquirido a partir de outros conteúdos, portanto, interligados. Entretanto, para GHIRALDELLI JUNIOR (1999), não faz parte da história da educação brasileira a cobrança de competências, vivências e participação dos alunos, mas, sim, reprodução de conteúdos, cobrança de informações, em detrimento das outras competências dos alunos. Afirma, também, que, diferentemente da cultura americana, nossos valores são individuais e não coletivos.

A escola frente a estas mudanças - na sua relação com o processo educativo - não pode deixar de lado a necessidade do indivíduo ter de adquirir algo, pois "se toda educação é sempre educação de alguém por alguém, ela supõe sempre também, necessariamente, a comunicação, a transmissão e a aquisição de alguma coisa" (FORQUIN, 1993, p.10). Pois por intermédio da escola não se produz qualquer saber, mas, sim, um saber mais elaborado, sistematizado e não fragmentado e espontâneo (SOARES, 1996). A sua existência relaciona-se à apropriação do conhecimento por parte das novas gerações (SAVIANI, 1997), mediante o acesso dos alunos ao conhecimento que a humanidade criou (VAGO, 
1995), sendo, ainda, sua função transmitir conhecimentos e habilidades científicas e culturais (RESENDE \& SOARES, 1996).

A partir de uma proposta de reforma educacional na Espanha, COLL (1996, p.12) destaca a importância dos conteúdos, afirmando que esses "designam o conjunto de conhecimentos ou formas culturais cuja assimilação e apropriação pelo alunos e alunas é considerada essencial para o seu desenvolvimento e socialização", considerando procedimentos, princípios, conceitos, fatos, atitudes, normas e valores como conteúdos de ensino e aprendizagem que precisam estar presentes nas escolas. Para FORQUIN (1993), a transmissão que ocorre na escola relaciona-se a conhecimentos, competências, crenças, hábitos e valores. Segundo SAVIANI (1997, p.23), os elementos envolvidos no saber escolar são: valores, atitudes, hábitos, símbolos e conceitos; afirmando que o "saber escolar" constitui-se de tal modo que:

(...) Para existir a escola não basta a existência do saber sistematizado. É necessário viabilizar as condições de sua transmissão e assimilação. Isso implica dosá-lo e seqüenciá-lo de modo que a criança passe gradativamente do seu não domínio ao seu domínio. Ora, o saber dosado e seqüenciado para efeitos de sua transmissão - assimilação no espaço escolar, ao longo de um tempo determinado, é que nós convencionamos chamar de 'saber escolar'.

Pensar a escola, na concepção de SAVIANI (1994), é vê-la como uma instituição social que veicula saber, na qual ocorre ensino e aprendizagem, ou seja, desde o senso comum até as mais elaboradas formulações, a escola é concebida como o lugar no qual se aprende e se ensina algum tipo de saber. Assim, nesse contexto, ao analisarmos as funções e objetivos da escola, refletimos sobre as seguintes questões: a qual escola faço referência? Pública ou particular? Para qual classe social? Não temos, neste estudo, a pretensão de responder a estas 
indagações, nem realizar retorno às origens da educação escolar, mas nos reportamos a SAVIANI $(1997, \mathrm{p} .12)$ que, de forma sintética, enfatiza que:

(...) desde a origem do homem pelo desenvolvimento de processos educativos inicialmente coincidentes com o próprio ato de viver os quais foram se diferenciando progressivamente até atingir um caráter institucionalizado cuja forma mais conspícua se revela no surgimento da escola. Esta aparece inicialmente como manifestação secundária e derivada dos processos educativos mais gerais mas vai se transformando lentamente ao longo da história até erigir-se na forma principal e dominante de educação. Esta passagem da escola à forma dominante de educação coincide com a etapa histórica em que as relações sociais passaram a prevalecer sobre as naturais estabelecendose o primado do mundo da cultura (o mundo produzido pelo homem) sobre o mundo da natureza. Em conseqüência, o saber metódico, sistemático, científico, elaborado passa a predominar sobre o saber espontâneo, 'natural', assistemático, resultando daí que a especificidade da educação passa a ser determinada pela forma escolar.

Também, preocupado com o conhecimento específico da escola, DOMINIQUE (1993, p.1-2) utilizou-se da denominação "cultura escolar" para designar o conjunto de saberes e de condutas que fazem parte da escola, afirmando que:

Poder-se ia descrever a cultura escolar como um conjunto de normas que definem o saber a ser ensinado e condutas a serem inculcadas e um conjunto de práticas que permitem a transmissão destes saberes e a incorporação desses comportamentos, normas e práticas estando ordenadas segundo finalidades que podem variar segundo as épocas (finalidades religiosas, sociopolíticas ou simplesmente de socialização). Normas e práticas não podem ser analisadas sem levar em conta o corpo profissional dos agentes que são chamados a obedecer a estas normas e que portanto, colocam em ação os dispositivos pedagógicos encarregados de facilitar sua aplicação, ou seja, os professores primários e secundários. 
O conhecimento levado à escola é denominado por FORQUIN (1992) como conhecimento "ensinável". Argumentando que a escola é o local por excelência de transmissão de saberes, onde ocorre "seleção cultural escolar", a qual consiste em buscar "quais são estes aspectos da cultura, quais são estes conhecimentos, estas atitudes, estes valores que justificam as despesas de toda natureza que supõem um ensino sistemático e sustentado por um aparelho institucional complexo" (p.31). Neste contexto, o currículo oculto também faz parte da cultura escolar, que consiste nos saberes, competências, representações, papéis e valores que não figuram nos programas oficiais, mas que ocorrem no diaa-dia da escola (FORQUIN,1993). Neste universo que representa o conhecimento escolar, para LARA (1996, p.186), os pais têm claro o que esperam da escola:

À escola os pais pedem saber, conhecimento para seus filhos, tem-se clara a noção de que esse saber está ligado a um fazer material e a um poder. Os pais pedem à escola saber, para seus filhos, a fim de que eles estejam aptos a fazer melhor as coisas, para adquirirem mais poder de ação (...). O compromisso específico da escola com a educação afunda suas raízes no compromisso com o saber, portanto, com o ensino.

O conhecimento escolar é organizado de forma peculiar e exige a participação de professores e alunos. Entretanto, não há neutralidade nesse processo, questões políticas e de poder a margeiam. Acreditar que a educação escolar é um empreendimento neutro é não querer ver a realidade. Sendo ou não conscientes a realidade é que a escola possui função educativa que não é neutra, ou melhor, nem a educação e nem a escola são neutras (NIDELCOFF, 1978).

Para o educador Paulo Freire, a escola é um espaço para a libertação, para a mudança, no qual a construção do conhecimento não ocorre somente pelo professor, pois, nesta concepção, professor e aluno aprendem juntos, construindo 
o conhecimento (FREIRE, 1979). Assim, sua pedagogia passa por um "itinerário que vai da cultura popular à cultura erudita e letrada, passando pela formação da consciência crítica" (GADOTTI, 1995, p.276). Nessa mesma linha de pensamento, apresentam-se os trabalhos de Snyciers, contudo, sua tese central baseia-se na escola como o lugar da "alegria"- título de um dos seus livros ressaltando-se que a escola está sempre adiando a felicidade, ou seja, tem-se que adiar a alegria para depois da escola, para os "intervalos" (SNYDERS,1988). Nessas percepções de ideologias marxistas, citadas anteriormente, na especificidade da escola também está presente o sistemático, o progressivo, a continuidade, as etapas, os pré-requisitos e a organização. Nesse enfoque, GADOTTI (1995, p.244-5) salienta que:

Fora da escola, as múltiplas formas de entretenimento, de educação continuada e de autoformação colocam, enfim, a presença de uma cultura no mesmo nível que a cultura escolar: teatros, concertos, museus, conferências, experiências científicas, televisão, cinema, vídeo, etc.. A diferença está justamente na sistematização. O que me parece caracterizar a escola é uma organização sistemática e contínua de situações. Há pré-requisitos, isto é, um grau de preparação considerado indispensável ao que se faz e, portanto, há uma certa homogeneidade de formação, de conhecimentos, da idade própria, etc. Procede-se por etapas, passo a passo. Há um programa progressivo.

A seleção do conhecimento levado para a escola, os currículos, o ensino que nela se encontra, as relações sociais que dominam as salas de aula e as influências do poder político e econômico no processo de reprodução cultural são questionados por APPLE (1982). O autor aponta para o fato de que a escolha de determinados conteúdos estão relacionados com as ideologias que a influenciam e, ainda, indagando acerca das ligações entre poder econômico e político e o conhecimento que é acessível aos estudantes, questiona: "a quem pertence esse 
conhecimento? Quem o selecionou? Porque é organizado e transmitido dessa forma e para esse grupo determinado?"(p.17). NIDELCOFF (1978) salienta que os conteúdos transmitidos na escola seguem duas vertentes: ou ajudam no sentido de formar pessoas críticas e a explicar a realidade, ou contribuem para torná-las alienadas; dependendo da ideologia a que o enfoque responde. Estas questões são desafios para a educação, principalmente quando se busca selecionar conhecimentos da cultura humana para serem organizados, sistematizados até chegarem aos currículos e assim às escolas.

Ao fazer referência às origens do termo currículo ou "curriculum", HAMILTON (1992) procura elucidar a dificuldade em precisar sua origem, uma vez que parece ter emergido da confluência de vários movimentos sociais e ideológicos. Situando, aproximadamente, o final do século XVI, como sendo origem do termo currículo, cuja palavra é latina e significa "corrida", ou "pista de corrida".

Para SAVIANI (1996), é preciso que se recupere o conceito abrangente de currículo, que consiste na "organização do conjunto das atividades nucleares distribuídas no espaço e tempo escolares. Um currículo é, pois, uma escola funcionando, quer dizer, uma escola desempenhando a função que lhe é própria" (p.23). O currículo pode ser uma fonte documental, um guia para professores, "em resumo, o currículo escrito nos proporciona um testemunho, uma fonte documental, um mapa variável do terreno: é também um dos melhores guias oficiais sobre a estrutura institucionalizada da escolarização"l (GOODSON, 1991, p.10).

\footnotetext{
${ }^{1}$ En resumen, el curriculum escrito nos proporciona un testimonio, una fuente documental, un mapa variable del terreno: es tambien una de las mejores guias oficiales sobre la estructura institucionalizada de la escolarizacion.
} 
Constitui, ainda, um instrumento utilizado por diferentes sociedades para "desenvolver os processos de conservação, transformação e renovação dos conhecimentos historicamente acumulados como para socializar as crianças e os jovens segundo valores tidos como desejáveis" (MOREIRA, 1994, p.11). Entretanto, entre o currículo formal, composto por planos e propostas; o currículo em ação ou real, que de fato acontece nas salas de aula e o currículo oculto, transmitido nas escolas, mas não mencionado nos objetivos e planejamentos dos professores há, segundo MOREIRA (1994), diferentes significados, uma vez que, nos documentos, há codificação representada e, nas escolas, são decodificados pelos indivíduos, o que sugere que a organização curricular é uma tarefa complexa.

Uma das características da organização curricular é a estruturação por disciplinas "onde há fronteiras bem nítidas; delimitações de território" (FORQUIN, 1992, p.37). Segundo CHERVEL (1990), a história das disciplinas, a divisão dos alunos por classes e níveis não está na natureza das dificuldades encontradas, mas, sim, na "própria constituição da disciplina que determina essa importante inovação na história pedagógica"(p.196). Esse processo de compartimentação do conhecimento em matérias ou disciplinas escolares e o uso do termo "disciplina" são provenientes de um processo histórico no qual verificase que:

O historiador é confrontado com um problema pouco usual aplicado ao ensino, a noção de "disciplina", independentemente de toda consideração evolutiva, não foi, nas ciências do homem, e em particular nas "ciências da educação", objeto de uma reflexão aprofundada. Demasiado vagas ou demasiado restritas, as definições que dela são dadas de fato não estão de acordo a não ser sobre a necessidade de encobrir o uso banal do termo, o qual não é distinguido de seus "sinônimos", como "matérias" ou "conteúdos" de ensino. A 
disciplina é aquilo que se ensina e ponto final. (CHERVEL, 1990, p. 177).

Para PHENIX ${ }^{2}$, citado no trabalho de $\operatorname{COLL}(1996$, p.77), o sentido de disciplina consiste em: "um bloco organizado de conhecimentos cuja propriedade, entre outras, é estar organizada adequadamente para o ensino e prestar-se à aprendizagem". Em SAVIANI (1994, p.14), a idéia de matéria ou disciplina escolar é vista como um conjunto de conhecimentos organizados para um fim que é a educação escolar. Levando-se em consideração a história peculiar de cada disciplina com sua autonomia, explicando que:

Embora seja possível estudar a evolução desta (s) ou daquela (s) disciplina (s) na história de determinado (s) currículo (s), cada disciplina tem, por sua vez, uma história 'autônoma', com trajetória própria, envolvendo fatores específicos e sofrendo-exercendo influências peculiares. Constitui-se, pois, num campo de estudos e pesquisas, cujo objetivo é investigar as 'transformações ocorridas numa disciplina ao longo do tempo', identificando 'fatores mais diretamente ligados às mudanças de conteúdo e métodos de ensino’.

Dessa maneira, cada matéria escolar tem sua própria história e suas peculiaridades, bem como relações políticas e de hierarquia que a constituem. Neste sentido, CHERVEL (1990, p.200) faz a seguinte indagação:

Há traços comuns às diferentes disciplinas? A noção de disciplina implica uma estrutura própria, uma economia interna que a distinguiriam de outras entidades culturais? Haveria um modelo ideal da disciplina em direção ao qual tendem todas as disciplinas em vias de constituição? Algumas disciplinas são melhor 'resolvidas' do que

\footnotetext{
${ }^{2}$ PH.H. PHENIX, The uses of disciplines as curriculum context. In: D.E. OLOSKY; B. OTHANEL SMITH, eds., Curriculum development: issues and insights, Chicago, 1978, p.83-89.
} 
outras? Há, dito de outro modo, matérias que se prestam mais do que outras a um processo de 'disciplinarização'?.

Nessa perspectiva, cabe a reflexão sobre os objetivos de uma disciplina e suas mudanças no decorrer da história. Nesse contexto, BITTENCOURT (1998, p.144) analisa que "as finalidades de uma disciplina mudam para atender a um público escolar diferenciado e como resposta às suas necessidades sociais e culturais inseridas no conjunto da sociedade". Os objetivos das disciplinas também são destacados por CHERVEL (1990, p.188) que explicita que "a instituição escolar é, em cada época, tributária de um complexo de objetivos que se entrelaçam e se combinam numa delicada arquitetura pela qual alguns tentaram fazer um modelo".

Parece ser um ponto crucial a organização e a constituição das disciplinas. Por que se escolhem determinadas disciplinas para compor o currículo escolar e não outras? Seguem-se as ciências como referência? As necessidades do mundo do trabalho? A formação integral do indivíduo? As necessidades de desenvolvimento do aluno? Afinal, como selecionar o conhecimento no seio da cultura da humanidade? Para BLANCO (1995), a seleção dos conteúdos, que serão adquiridos pelos alunos, deverá ser cuidadosa, planejada, intencional e levar em consideração que estes não são um fim em si mesmos, mas sim, um meio para o desenvolvimento do indivíduo. Ressalta, ainda, que os conteúdos a serem oferecidos na escola, precisam ser ampliados, não sendo enfatizado somente o desenvolvimento cognitivo, como conteúdos do tipo fatos, princípios e conceitos, mas, também, conteúdos como valores, normas, atitudes e procedimentos, assim, "selecionar conteúdos adequados às possibilidades, necessidades e interesses dos indivíduos para que a aprendizagem seja significativa" (p.311). 
Ainda neste enfoque, MOREIRA (1994, p.12) faz o seguinte questionamento: "o que deve um currículo conter? Como organizar esses conteúdos? Como selecionar as experiências de aprendizagem a serem oferecidas? Como organizá-las relacionando-as aos interesses e ao desenvolvimento do estudante?".

No trabalho de TYLER (1976) sobre currículo e ensino, já aparecem as dificuldades na elaboração de objetivos claros e específicos que dão, muitas vezes, lugar a objetivos bastante amplos, inadequados e pouco prováveis de serem atingidos. Estes, segundo o referido autor, influenciam na eficácia da aprendizagem, cuja escolha das experiências de aprendizagem passam por critérios, retirados da psicologia educacional, como a seqüência de desenvolvimento na qual se encontra a criança.

O conhecimento escolar deve ser o resultado de uma prática coletiva que envolve uma série de transformações até resultar em um novo produto, para o qual a didática apresenta papel fundamental nesse processo (SANTOS, 1994). Para De SANTO (1993, p.40), há um grande peso na relação entre as ciências de referência e os conteúdos a serem ensinados pelas disciplinas escolares, destacando que:

A definição do que uma disciplina escolar ensina, seu objeto central do qual saem os conteúdos não é dado pela escola, tão pouco pelas faculdades de educação. São os institutos de origem daquelas disciplinas que fazem a caracterização deste objeto de estudo ou área de conhecimento e, junto com as faculdades de educação e profissionais da filosofia da educação, transformam o conhecimento acumulado na área em currículos, conteúdos, programas, estratégias e atividades através dos quais se dará a educação escolarizada dos jovens. 
Entretanto, à escola não basta somente o que the é imposto pela sociedade e a cultura que a rodeia, assim como às disciplinas escolares não é suficiente restringir-se às ciências de referência; é preciso que a escola crie um modelo próprio, atendendo às suas necessidades (CHERVEL, 1990). Contudo, nem sempre há correspondência entre as disciplinas escolares e os saberes de referência, nos quais a escola, por mais que se esforce, dificilmente consegue acompanhar os avanços das ciências (SAVIANI, 1994). Por conseguinte, o papel da escola precisa ir para além da informação, mas também para a formação do indivíduo. Não basta o conhecimento das ciências de referência ou o acervo cultural da humanidade nas escolas. É preciso ter critérios no processo de seleção desse conhecimento, organização, sistematização e outros mecanismos intermediários.

Aos professores, não cabe tão somente transmitir conhecimentos, pois eles constroem saberes, resultado de suas práticas pedagógicas e experiências de vida (BORGES, 1998). A educação escolar, para tornar assimiláveis os saberes e materiais culturais, deverá realizar um imenso trabalho de transposição didática, pois a ciência do erudito não é diretamente comunicável ao aluno, assim como a obra do escritor e o pensamento do teórico (FORQUIN, 1992). Enfim, a escolha dos conteúdos a serem levados para a escola depende do contexto, das necessidades, daqueles que decidem as políticas educacionais, dos professores, dos alunos e das especificidades de cada disciplina ou componente curricular. É preciso que haja progressividade, seqüência, organização, ensinar o que realmente "valha a pena", o que de mais significativo é produzido pela humanidade, fazer escolhas pedagógicas e as justificar (CHERVEL, 1990; FORQUIN, 1993; SANTOS, 1994; SAVIANI, 1994). 
Além dos elementos apontados no processo de seleção dos conteúdos a serem levados para a escola, as relações entre inteligência, aprendizagem e desenvolvimento norteiam esta escolha. GARDNER (1995) argumenta a favor da teoria das Inteligências Múltiplas, que consiste na existência de várias inteligências independentes uma das outras, como um espectro de múltiplas competências, composto de sete tipos de inteligência, a saber: pensamento lingüístico, musical, lógico-matemático, espacial, corporal cinestésico, interpessoal e intrapessoal. Assim, cada pessoa possui essas capacidades em diferentes graus, portanto, ninguém é igualmente inteligente, sendo que mesmo o gênio, tende a ser específico em determinados conteúdos. Assim sendo, para o autor possuímos várias inteligências, afirmando que:

Uma inteligência é a capacidade de resolver problemas ou de criar produtos que sejam valorizados dentro de um ou mais cenários culturais. (...) Baseando-se nesta definição e especialmente em evidências biológicas e antropológicas introduzi, então, oito critérios para uma inteligência e propus sete competências humanas que preenchem basicamente estes critérios. (...) A meu ver, a mente possui potencial para lidar com diversos tipos de conteúdos, mas a facilidade de um indivíduo com determinado conteúdo apresenta pouco poder prognóstico sobre sua facilidade com outros tipos de conteúdo. Em outras palavras, o gênio (e, a fortiori, o desempenho comum) tende a ser específico a conteúdos particulares: os seres humanos evoluíram até apresentar diversas inteligências e não se basearam de formas diferentes em uma inteligência flexível. (GARDNER, 1995, p.2).

No clássico debate acerca da concepção de inteligência inata ou adquirida, realizado entre os pesquisadores Chomsky e Piaget, no Centre Royamount Pour Une Science De L'homme, em 1975, e transformado em livro por PIATELLI \& PALMARINI (1983), remete à ontogênese do conhecimento e seu significado epistemológico. Para PIAGET (1973), não há conhecimento 
resultante de simples registro de observações, nesta perspectiva, não há no homem estruturas cognitivas a priori ou inatas, ou seja, o conhecimento é algo que se constrói no decorrer do desenvolvimento, assim, somente o funcionamento da inteligência é hereditário e gera estruturas mediante a ação sobre os objetos. $\mathrm{O}$ pesquisador Chomsky, no debate, argumenta a favor das estruturas inatas, ou seja, a criança possui competência intrínseca e desenvolve sistemas de desempenho para usar esse saber.

$\mathrm{Na}$ epistemologia construtivista piagetiana, citada por RANGEL (1990), as estruturas da inteligência são construídas, progressivamente, pelo indivíduo no processo de adaptação ao meio, assim, sujeito e mundo que o cerca estão em constante interação, o autor enfatiza que "não é possível conceber a ação isolada promotora de desenvolvimento, mas ela só se efetiva quando o sujeito age para transformar o mundo, atribuindo-lhe um significado" (p.76).

Ainda na teoria piagetiana, é descrita a existência de estágios universais no processo de desenvolvimento, iguais para todas as crianças em função de suas idades, pelos quais as crianças passam por sucessivos patamares, em contínuo movimento de "equilibração" a saber: a) período sensório-motor: anterior à linguagem, fecundo em descobertas e invenções; b) período pré-operatório: dos dois aos sete anos, com conceptualização das ações, mas sem operações reversíveis e sem conservações; c) período das operações concretas: dos sete aos dez anos, com agrupamentos logicamente estruturados, mas ainda ligados à manipulação dos objetos; d) período hipotético-dedutivo: por volta dos 11,12 anos, constituído da lógica proposicional. A inteligência, nessa concepção, consiste na capacidade individual de acomodação ao meio desenvolvendo-se por estágios de "equilibração" progressiva, ou seja, de um estado de menor equilíbrio 
para um estado de equilíbrio superior e o conhecimento da interação sujeito e objeto.

Nos trabalhos clássicos de Gesell, citado por ROMERO (1995), o conceito de maturação é fundamental para a compreensão sobre o desenvolvimento, que seria, essencialmente, regulado por fatores internos, assim, as mudanças atribuíveis à maturação são independentes da aprendizagem nessa concepção. A idade cronológica é outro fator presente, no qual as mudanças ocorrem em uma ordem seqüencial e invariável, que funciona como indicador fundamental do grau de maturação ou prontidão. Para GAGNÉ (1980), a mudança comportamental persistente, mais resultante do desenvolvimento de estruturas internas, é denominada de maturação, já a mudança comportamental, fruto da interação com o meio ambiente, consiste na aprendizagem. Dessa forma, a aprendizagem acaba não interferindo no curso do desenvolvimento e verifica-se que ocorreu aprendizagem a partir das modificações no comportamento da criança, que passa por fases de aprendizagem, como em um encadeamento lógico, a saber: a) fase de motivação; b) fase de apreensão; c) fase de aquisição; d) fase de retenção; e) fase de rememoração; f) fase de generalização; g) fase de desempenho e h) fase de feedback. Resultando, daí, cinco categorias de capacidades humanas aprendidas: informação verbal, habilidades intelectuais, estratégias cognitivas, atitudes e habilidades motoras.

A polêmica, em torno do papel que o meio ambiente e a herança genética desempenham no processo do desenvolvimento, é explicitada, por PALÁCIOS (1995a) a partir do entendimento de que nosso código genético possui certos conteúdos "fechados" e outros "abertos". São fechados no sentido que não são alteráveis em conseqüência da espécie e de suas características morfológicas, determinados pelo calendário maturativo; abertos à medida que 
certas aquisições são possíveis pelas interações da pessoa com seu meio. Definir aprendizagem não é tarefa fácil. GARCIA (1988, p.24) a define como um processo de exclusão, esclarecendo os seguintes aspectos:

(...) Os psicólogos, por exemplo, vêem a aprendizagem como uma mudança relativamente permanente do comportamento; já os biólogos falam em mudanças adaptativas do comportamento; para os fisiologistas ela significa algum tipo de alteração no substrato neural, alteração inferida na maior parte das vezes, claro está. Mas, se falamos em alterações estáveis ou relativamente estáveis, é necessário, primeiro diferenciá-la, a aprendizagem, daquelas alterações transitórias determinadas pela adaptação sensorial, pela fadiga ou pelas flutuações do estado motivacional, e depois das outras alterações definitivas resultantes do crescimento e da maturação.

VYGOTSKY (1994), ao fazer referência à tese de Piaget, comenta que o desenvolvimento está sempre adiantado em relação à aprendizagem, sendo que trata-se de um pré-requisito para o aprendizado, ou seja, "para resumir essa posição: o aprendizado forma uma superestrutura sobre o desenvolvimento, deixando este último essencialmente inalterado" (p.105). Assim, segundo BONETI (1986), na teoria de Piaget, a criança passa por fases e estágios independentes do conhecimento que tenha recebido. Portanto, a aprendizagem e o ensino pouco influenciam o curso do desenvolvimento. $\mathrm{Na}$ análise de VYGOTSKY (1994), há, ainda, duas outras teorias que precisam ser consideradas: a que afirma que aprendizagem é desenvolvimento, nos quais os dois processos ocorrem simultaneamente, e a segunda posição teórica de KOFFKA $^{3}$ citado por VYGOTSKY (1994), que constitui uma síntese das

\footnotetext{
${ }^{3}$ K. KOFFKA, O problema do desenvolvimento na psicologia estrutural. In: Fundamentos do desenvolvimento psicológico, Moscou, Sozekgiz, 1934.
} 
anteriores, ou seja, aprendizagem e desenvolvimento não coincidem, pois o processo de aprendizado estimula e empurra o processo de maturação. Dessa forma, a aprendizagem não está limitada à maturação e ao desenvolvimento. $\mathrm{O}$ conceito de internalização é um dos elementos principais na obra de Vygotsky e significa que, ao longo do desenvolvimento, os processos sociais são transferidos do plano externo para o interno (MARCHESI \& MARTÍN, 1995). Na relação entre aprendizado e nível de desenvolvimento da criança, VYGOTSKY (1994, p.112) acrescentou o conceito de zona de desenvolvimento proximal, afirmando que:

Ela é a distância entre o nível de desenvolvimento real, que se costuma determinar através da solução independente de problemas, e o nível de desenvolvimento potencial, determinado através da solução de problemas sob a orientação de um adulto ou em colaboração com companheiros mais capazes.

A aprendizagem, orientada nessa concepção de zona de desenvolvimento proximal, segundo BONETI (1986, p.31), significa que "não precisa esperar que todo o ciclo de maturação de determinadas funções se complete para que ela possa acontecer, então a função da escola e o papel do professor também ganham nova conotação". Assim, a aprendizagem, voltada somente para aquelas funções que já estão desenvolvidas, é insuficiente. Neste sentido, o aprendizado está sempre à frente e provoca mudanças no desenvolvimento, portanto, o ensino escolar, nesta visão, trabalha com desafios que impulsionam a criança a utilizar sua capacidade potencial. Para ECHEITA \& MARTÍN (1995), não se trata de optar pela teoria de Vygotsky ou a de Piaget, já que ambas são válidas, no entanto, ambas possuem níveis diversos de aplicação e 
considerações, uma vez que o contato social tem diferentes pesos no desenvolvimento.

Conhecer o modo como os indivíduos aprendem e se desenvolvem tem sido uma extensa tarefa das áreas da Psicologia e da Pedagogia. Existem divergências entre as teorias relacionadas às mesmas, e a escolha por uma delas influi na atuação escolar. Podemos perceber esta influência na compreensão sobre o conhecimento escolar e sobre os conteúdos de ensino que serão prioridades. Contudo, para este estudo, não desconsiderando a importância das teorias sobre aprendizagem e desenvolvimento, a opção é pelos trabalhos sistematizados de COLL, POZO, SARABIA \& VALLS (1998).

Nesta visão, o desenvolvimento dos seres humanos nunca ocorre no vazio, mas inserido num contexto social e cultural determinado. Dessa maneira, o entendimento sobre o crescimento pessoal é percebido como:

(...) O processo através do qual os seres humanos tornam seus os conhecimentos e formas culturais do grupo social ao qual pertencem. Essa assimilação, entretanto, não consiste em uma incorporação passiva do conhecimento historicamente construído e culturalmente organizado, mas em uma reconstrução ou reelaboração do mesmo. É assim que, através da assimilação dos conhecimentos culturais e apesar deles serem, em princípio, os mesmos para todos os integrantes de um grupo social, cada um de seus membros acaba se tornando um indivíduo único e irrepetível. (COLL et al., p.12).

Os conteúdos escolares, nesta concepção, apresentam destaque, pois são considerados importantes para a produção do desenvolvimento e socialização adequados dos alunos. Ensino e aprendizagem de conteúdos, assim, não são um fim em si mesmo, mas um meio para o desenvolvimento dos alunos. Para que assim possam construir significados e atribuir sentido àquilo que aprendem. A 
mensagem pedagógica contida nesta percepção, pode ser visualizada da seguinte maneira:

Entre outras coisas, supõe uma tentativa de romper com a prática habitual, justificadamente denunciada em inúmeras ocasiões, de um ensino centrado excessivamente na memorização mais ou menos repetitiva de fatos e na assimilação mais ou menos compreensível de conceitos e sistemas conceituais. Mas supõe também, o que poderia ser ainda mais importante, uma tentativa de acabar com uma certa tradição pedagógica que, de forma totalmente injustificada, exclui do ensino sistemático um certo tipo de formas e conhecimentos culturais, cuja importância está fora de qualquer dúvida e cuja assimilação é deixada inteiramente a única e exclusiva responsabilidade dos alunos. (COLL et al., p.15).

Dessa forma, o excessivo peso atribuído aos conteúdos relativos a fatos e conceitos, presentes de maneira desproporcional nos currículos escolares, dá lugar a outros tipos de conteúdos que precisam ser considerados, ou seja, os procedimentos e as atitudes; os valores e as normas. Assim, os conteúdos curriculares designam "o conjunto de conhecimentos ou formas culturais cuja assimilação e apropriação pelos alunos e alunas é considerada essencial para o seu desenvolvimento e socialização" (COLL et al., 1998, p.12). Entretanto, cabe destacar que a aprendizagem de um determinado conteúdo, não ocorre isoladamente, pois os conteúdos, quer sejam conceitos, procedimentos, ou atitudes, apresentam-se interligados.

Dessa forma, COLL et al. (1998) considera que os procedimentos e as atitudes; os valores e as normas, em igualdade com os conteúdos do tipo fatos e conceitos, não são questão de terminologia, mas, sim, de aceitar o princípio de que o que pode ser aprendido pelos alunos pode ser ensinado pelo professores. 
Segundo POZO (1998), a aprendizagem de fatos e conceitos apresenta variação de uma matéria do currículo para a outra. Podendo-se complementar em muitos contextos, ou apresentar-se como dois extremos de um contínuo. Assim, nesse caso, os fatos e os dados são aprendidos de modo memorístico, com enfoque de orientação passiva com relação à aprendizagem. Entretanto, a aquisição de conceitos baseia-se na aprendizagem significativa, relativa ao que o aluno deve "saber", mediante uma atitude mais ativa do aluno com relação à aprendizagem, ou seja, o aluno não é um "quadro em branco", ele chega à escola com muitos conhecimentos adquiridos. Nesse sentido, para o referido autor "não basta somente reproduzir informação nova, também é preciso assimilá-la ou integrá-la aos nossos conhecimentos anteriores. Somente assim compreendemos e adquirimos novos significados ou conceitos" (POZO, 1998, p.32).

Os procedimentos são outro tipo de conteúdos que merecem destaque, mas, para COLL \& VALLS (1998), os mesmos possuem pequena ênfase nos currículos escolares, quando comparados à aprendizagem de fatos e conceitos. Nesta concepção, os procedimentos encerram conhecimentos sobre a capacidade de "saber fazer", de saber agir de maneira eficaz, orientado para a realização de uma meta. Dessa forma, os conteúdos procedimentais são designados conforme as considerações dos referidos autores:

Conjuntos de ações, de formas de agir e de chegar a resolver tarefas. Trata-se de conhecimentos referentes ao saber fazer coisas (com as coisas ou sobre as coisas, as pessoas, a informação, as idéias, os números, a natureza, os símbolos, os objetos etc.). (COLL \& VALLS, 1998, p.92).

Nesse entendimento, os conteúdos procedimentais não são algo novo, cabe ressaltar que o termo "procedimental", não existe na língua portuguesa, nem 
na lingua inglesa, e no entanto este termo aparece nos Parâmetros Curriculares Nacionais -, na prática são denominados por hábitos, técnicas, habilidades, estratégias, métodos, rotinas etc. No entanto, tratando-se de planejamento e sistematização do conhecimento escolar, eles são pouco enfatizados, pois a escola destaca os conteúdos factuais e conceituais.

Sendo assim, não há atividades que valem mais do que outras, ou seja, não há visão dicotômica das atividades humanas. A aprendizagem de procedimentos não significa "somente aprender os enunciados das fórmulas, das regras de atuação, das instruções sob os quais são apresentados, mas também saber pô-los em prática" (COLL \& VALLS, 1998, p.95).

Um outro tipo de conteúdo que aparece nos currículos escolares são as atitudes, que enfatizam o "ser". No entanto, nem sempre estão explícitos e sistematizados. As atitudes envolvem um componente afetivo, cognitivo e o fator comportamental, relativo à tendência a realizar ações. Nesse contexto, SARABIA (1998, p.122) defini atitudes como "tendências ou disposições adquiridas e relativamente duradouras a avaliar de um modo determinado um objeto, pessoa, acontecimento ou situação e a atuar de acordo com essa avaliação". Assim, os conteúdos atitudinais diferenciam-se dos valores, pois estes últimos incluem a crença de que o objeto é desejável independente da própria posição da pessoa. Desse modo, a instituição educativa não deve se limitar a ensinar conhecimentos, habilidades e métodos, e expressa que cabe à escola:

Desenvolver na criança uma moral cidadã e critérios de autonomia que sejam solidários e representem um compromisso com a sociedade onde vivem. Os novos currículos reservam um espaço importante nos seus conteúdos, para que os alunos se conscientizem e despertem a sua curiosidade por outras formas de vida, valores, línguas e raças 
existentes no mundo e dentro de sua própria nação. (SARÁBIA, 1998, p.127).

Propiciar aos alunos um debate sobre as atitudes, valores e normas que os cercam, ampliam as perspectivas pedagógicas, merecendo destaque nos currículos escolares. Entretanto, nem sempre os professores estimulam os alunos para que isso ocorra e, muitas vezes, falta compreensão sobre as necessidades de aprendizagem e desenvolvimento das crianças e dos jovens.

$\mathrm{O}$ aluno da quinta à oitava séries, em condições ideais, segundo BRASIL (1998c), encontra-se na faixa etária de 11 a 14 anos de idade - período este denominado de pré-adolescência e adolescência -, mas, tratando-se de realidade brasileira, o universo que compõe essas séries apresenta idades diferenciadas, composto, principalmente, por alunos mais velhos, com 16, 17, 18 anos ou até mais. Nesse sentido, caracterizar os alunos neste período da educação escolar, momento este singular de construção de suas identidades e elaboração de projetos, não é tarefa das mais fáceis, uma vez que as diferentes situações socioeconômicas em que vivem, bem como as experiências, a diversidade cultural e individual não pode ser esquecida.

Segundo PALÁCIOS (1995b, p.265), a adolescência costuma ser confundida com a puberdade, entretanto, a puberdade é universal enquanto fenômeno biológico maturativo comum à nossa espécie, já a adolescência não é a mesma em todas as culturas, por ter relação com o aspecto psicológico e sofrer variações históricas, conforme se pode perceber nas seguintes considerações: 
Chamamos puberdade ao conjunto de modificações físicas que transformam o corpo infantil, durante a segunda década de vida, em corpo adulto, capacitado para a reprodução. Chamamos de adolescência um período psicossociológico que se prolonga por vários anos, caracterizado pela transição entre a infância e a adultez.

A adolescência pode ser considerada uma etapa, um período de transição entre a infância e a idade adulta, no qual não se é mais criança e, ao mesmo tempo, ainda não se é adulto, entretanto, a adolescência não é um mero intervalo entre a infância e a idade adulta. Neste processo, não há descontinuidade no desenvolvimento, daí a importância da história evolutiva anterior e os projetos de elaboração do futuro. Assim, a construção da identidade pessoal vinculada à própria história do adolescente, o grupo de amigos, a sexualidade, os valores e as experiências são fundamentais na relação do adolescente com o seu meio (FIERRO, 1995). Esta etapa da vida, segundo o Estatuto da Criança e do Adolescente, compreende o período que vai dos 12 até, aproximadamente, os 18 anos (BRASIL, 1998c). Todavia, a adolescência, em diferentes períodos históricos e em diversas sociedades, não é vista da mesma maneira, por sofrer influências da cultura e de cada sujeito concreto (PALÁCIOS, 1995b).

A imagem da adolescência como período de tensões, conflitos, dramas, como uma idade de turbulência e tempestades, segundo FIERRO (1995), precisa ser considerada com certa cautela, pois não corresponde à realidade da maioria dos jovens, o autor alerta para o fato do sensacionalismo que é feito em torno das expectativas do comportamento dos jovens que acabam por influenciar em suas condutas.

Ao identificar alguns traços dos adolescentes, PALÁCIOS (1995b) denominou "cultura de adolescente" o fato de "ter suas próprias modas e hábitos, seu estilo de vida próprio, e seus próprios valores; por ter preocupações e 
inquietudes que não são mais as da infância, mas que ainda não coincidem com as dos adultos" (p.264). Enfatiza as dificuldades dos pais e professores em compreender as necessidades dos jovens, dizendo que são problemáticos e que não sabem o que querem. Contudo, citou os conflitos que os pais passam, como crises da meia idade, redefinição profissional e de identidade que influenciam a maneira como lidar com os jovens. Outro fato assinalado é a escola pouco motivadora, sem utilidade clara para os jovens e para o exercício de suas profissões. Assim, "os adolescentes estariam, muitas vezes, em seu direito, se respondessem aos pais e educadores que estes não sabem o que lhes oferecer" (PALÁCIOS, 1995b, p.270).

As mudanças fisicas acentuadas e aceleradas durante a adolescência, também precisam ser consideradas, pois provocam alterações na construção da sua auto-imagem, auto-estima e, portanto, interferem na construção de suas identidades individuais e coletivas. Como exemplo, assistimos, nas mais diferentes regiões, a formação de grupos de jovens em torno do "rock", "rap", "reggae", basquetebol, entre outros, como uma necessidade dos jovens em fazer parte de grupos e ser aceito pelos mesmos. Além do fato de parcelas das camadas populares das grandes metrópoles serem socializadas dentro de uma cultura da violência, e os apelos de toda ordem em que são expostos os jovens, principalmente, pelos meios de comunicação que vendem uma imagem de jovem com objetivos, incentivando ao consumo e, que acabam influenciando o comportamento dos mesmos, daí a importância da família como referência para seus projetos de vida (BRASL, 1998c).

No âmbito destas discussões, a escola pode ser um espaço privilegiado de reflexão e problematização sobre as questões que auxiliem os jovens a compreender seu próprio corpo e sua sexualidade, as mudanças biológicas que 
estão ocorrendo e resgatando a auto-estima dos adolescentes, comprometida pelas discriminações e modelos estereotipados vendidos pela mídia, auxiliando no processo de construção de suas identidades. A escola pode proporcionar compreensão em relação às manifestações culturais dos jovens, respeitando os diferentes estilos visuais que são, muitas vezes, estranhos aos adultos. Os professores podem influenciar na construção da auto-imagem dos alunos, não no sentido do confronto, mas de auxiliar no desenvolvimento de suas capacidades, a fim de que os alunos se sintam aptos, confiantes e não fracassados. Freqüentemente, ocorre que os alunos, que demonstram maior potencial, são os que os professores dão maior atenção e incentivo e os jovens problemáticos e indisciplinados, no entanto, são os que os professores apresentam maior desânimo em auxiliar (BRASIL, 1998c).

A aprendizagem, nesta fase da vida, ou seja, na adolescência, é um elemento para a compreensão de como pensam os jovens. O adolescente, segundo CARRETERO \& CASCÓN (1995), atinge um nível novo de pensamento o qual irá permiti-lo conceber os fenômenos de maneira diferente de como o fazia na infância. Esta fase caracteriza-se, na tradição piagetiana, como a das operações formais ou abstratas, nas quais os adolescentes serão capazes de estabelecer relações entre as causas e efeitos e fazer combinações, mediante a conquista de um pensamento do tipo abstrato ou teórico, capazes, ainda, de formular hipóteses. Entretanto, o trabalho do educador nesta linha de pensamento deveria consistir como nos apontam os autores em:

Potencializar, no adolescente, o pleno desenvolvimento desse pensamento. No entanto, as coisas não são tão simples. (...) As investigações realizadas nos últimos vinte anos indicam que não se adquire o pensamento formal tão facilmente, nem de forma tão homogênea como previram Inhelder e Piaget, e por isso é perigoso 
reduzir a importância dos conteúdos escolares. (...) Não se pode conceber o desenvolvimento à margem da aprendizagem, seja escolar ou informal. Em outras palavras, se a aquisição do pensamento abstrato ou formal, na adolescência, depende, em grande parte, da experiência do sujeito por suas teorias ou idéias prévias, é evidente pensar que pelo menos uma grande parte dessa experiência é adquirida ou deveria ter sido adquirida na escola. (CARRETERO \& CASCÓN, 1995, p.27986).

Compreender o jovem, suas necessidades, singularidades, em seus mais diversos aspectos, constitui um referencial para a estruturação dos objetivos para a quinta à oitava séries do ensino fundamental. A seleção dos conteúdos que compõe os diferentes componentes curriculares também pode entender o jovem para o processo de escolha dos mesmos. Nessa perspectiva, o componente curricular educação física poderá contribuir para a educação dos jovens dentro de sua especificidade.

\subsection{Educação, educação física da quinta à oitava séries do ensino fundamental}

O componente curricular Educação Física encontra-se em um contexto mais amplo que é a educação e, portanto, sofre influências da mesma. Em um breve retorno à história, verificamos que a Educação Física aparece nos currículos escolares em nosso país com o nome de ginástica, em 1851, Lei $\mathrm{N}^{\circ} .630$ de 12set-1851 (BETTI, 1991; SILVA,1994), de maneira que:

Ao longo da história do homem, formas de atividade física, considerada esta de forma ampla e mesmo de Educação Física, surgiram em todos os momentos, em maior ou menor grau, com maior ou menor institucionalização. Entrementes, desconsiderando-se a antigüidade grega, foi nas últimas décadas do século XVIII, e em especial durante 
o século XIX, que a Educação Física experimentou um decisivo impulso no sentido de sua sistematização e institucionalização como uma forma de educação no mundo ocidental. (BETTI, 1991, p.33).

A Educação Física ocupou diferentes posições e tendências ao longo dos diferentes momentos históricos. GHIRALDELLI JUNIOR (1992) faz um resgate de cinco tendências da educação física no Brasil: "Educação Física Higienista (até 1930); Educação Física Militarista (1930-1945); Educação Física Pedagogicista (1945-1964); Educação Física Competitivista (Pós 64); e, finalmente, a Educação Física Popular" (p.16). Assim, no decorrer do processo histórico "o que se ensinou ou se ensina em Educação Física na escola tinha, e tem, vinculação direta com os momentos históricos vividos em nosso país e no mundo" (VAGO, 1995, p.21).

Pelo exposto, o contexto mais amplo, no qual se encontra inserida a Educação Física escolar, precisa ser considerado quando se trata de escola, ou seja, não podemos fugir das influências que sofremos, como afirma PILETTI (1996). Este, ao analisar a educação escolar em nosso país, considerou o contexto atual complicado, à medida que, hoje, os problemas são imensos, graves e foram acumulando ao longo dos anos. Ao fazer referência aos problemas da educação, ele enfatiza os elevados índices de analfabetismo - quando comparados aos países pobres da África - a grande quantidade de crianças que estão fora da escola apesar da nossa Constituição determinar o direito da criança à escola - ; além das condições de trabalho do professor. Nesse prisma, CORTELLA (1995, p.5), ao enfocar a escola pública no Brasil, afirmou que "a crise da Educação no Brasil não é uma crise, é um projeto das elites e ainda continua em execução, gerando uma fabulosa estrutura de produção do fracasso escolar". A valorização do professor é outro aspecto que também precisa ser considerado. Assim, para MACHADO (1997, p.174), “a valorização da função docente é uma tarefa 
urgente, imprescindivel, fundamental". Ressalta, também, a questão salarial, as precárias condições de trabalho do professor e sua formação que nem sempre são adequadas.

A Educação Física não pode ficar alheia aos problemas relativos à educação e que, muitas vezes, são ignorados como os citados por SADDI (1998): "a teoria educacional nos marcos do neoliberalismo, as relações da educação com o mundo do trabalho, a democracia, a política social, educacional e a inclusão exclusão de jovens e adultos na vida política e social" (p.50). Afirma que a Educação Física busca os pensamentos na educação, quando a convém, desligando-se, constantemente, da mesma. É necessário que esta interlocução seja uma constante a fim de que a Educação Física seja, realmente, da escola e não esteja, simplesmente, desvinculada da mesma (CAPARROZ, 1997).

Pelo exposto, compreender as relações entre a quinta à oitava séries e a Educação Física, passa pelo entendimento sobre o âmbito escolar, pois é onde se insere este componente curricular. Assim, consideramos pertinente elaborar uma breve reflexão histórica sobre a educação escolar em nosso país, enfatizando as referidas séries.

Cabe antes ressaltar que é difícil encontrar momentos nos quais a educação escolar foi realmente prioritária no Brasil; não somente em termos de discurso político. No período colonial, a preocupação principal era a de formar as elites, com ênfase para o ensino secundário e superior em detrimento do ensino primário, sem a articulação entre os níveis e sem exigência hierárquica entre os mesmos (PILETTI, 1996 ). Durante a década de 1920 à 1930, inicia-se um processo de discussão sobre o modelo existente que visava à formação de elites. Em seu lugar, era proposto um sistema nacional de educação no qual houvesse articulação entre os níveis do primário ao superior. Entretanto, este processo de 
discussão só se concretiza no plano da lei a partir da constituição de 1934. Assim, "no final da Primeira República, em matéria educacional, pouco ou nada haviamos avançado em relação ao final do Império" (PLETTI, 1996, p.74).

Pela primeira vez, na Constituição de 1934, há um capítulo especial sobre a educação, quando foram criados ministérios e secretarias. O presidente da época, Getúlio Vargas, citado por CUNHA (1981, p.3), afirma, em um dos seus discursos: "é preciso que todos os brasileiros recebam educação". Há no discurso fins políticos, de cunho demagógico e nacionalista, entretanto, não se pode deixar de considerar que a educação teve um espaço neste sistema de governo.

Foi durante o governo de Getúlio Vargas, graças ao Ministro da Educação, Gustavo Capanema, que encontramos as raízes da quinta à oitava séries, que, naquele momento, pertenciam ao ensino secundário, que hoje, no entanto, fazem parte do ensino fundamental, segundo a Lei 9.394, de Diretrizes e Bases da Educação Nacional, promulgada em dezembro de 1996. CUNHA (1981), ao se referir à reforma do então Ministro da Educação da era Vargas, relata que o ensino secundário apresentava dois ciclos: o primeiro com duração de quatro anos - chamado de ginásio - e o segundo com duas modalidades de cursos: o clássico e o científico, com duração de três anos. O chamado ginásio de antigamente, com duração de quatro anos, juntamente com o colegial, com duração de três anos, faziam parte do ensino secundário. $\mathrm{O}$ ensino primário possuiu tendências mais democráticas, uma vez que se destinava às camadas populares, ao contrário dos níveis secundário e superior, historicamente reservados à formação das elites (XAVIER, 1990).

A partir da Lei de Diretrizes e Bases da Educação Nacional, promulgada em 1961, na chamada República Populista, é que se buscou ampliar o acesso à escola pública e gratuita (PILLETTI, 1996). Estava previsto, por essa lei, 
o ensino primário com duração mínima de quatro e o ensino chamado de médio em dois ciclos: o ginasial de quatro anos e o colegial de três anos, portanto, encontramos, novamente, a quinta à oitava séries juntamente com o ensino secundário, além da passagem do primário para o ginásio, mediante a obrigatoriedade de realização de exame de admissão.

A partir de 1964, com o regime da ditadura militar, os avanços e conquistas populares foram contidos e passamos por um período dos mais dificeis de nossa história, cujas conseqüências sofremos até hoje (PILETTI,1996). Cabe ressaltar que uma das contradições desse sistema consistiu em estender a educação para as camadas populares. Com a Lei $\mathrm{N}^{\circ}$. 5.692, promulgada em 1971, os cursos primário e ginasial foram unificados num único curso de primeiro grau, com duração prevista para oito anos. Contudo, apesar da unificação, na prática, verificou-se que os cursos apresentaram uma passagem de ruptura, fruto da própria história, ou seja, unificaram-se na Lei e não na prática pedagógica, como pode ser assim percebido:

Suprimiu-se, em 1971, o exame de admissão ao ginásio, com a fusão do primário e do ginásio num único nível de ensino, o $1^{\circ}$ grau, mas na prática, essa integração ainda não ocorreu plenamente: as quatro primeiras séries do $1^{\circ}$ grau absorveram as características do antigo primário (um professor por classe etc.), enquanto as quatro últimas séries herdaram as características do antigo ginásio. Dessa forma, a passagem da $4^{\mathrm{a}}$ série para a $5^{\mathrm{a}}$, embora não exija exame especial, ainda constitui uma ruptura brusca para o aluno. (PILETTI,1996, p.99-100).

A partir da Lei №. 9.394, de 20 de dezembro de 1996, que estabelece as Diretrizes e Bases da Educação Nacional (LDB), organizam-se os níveis da educação escolar em: "I- educação básica, formada pela educação infantil, ensino fundamental e ensino médio; II- educação superior" (BRASIL,1998a, cap. I, 
art.21). $\mathrm{O}$ ensino de primeiro grau, que agrupava o antigo primário e o ginásio, passa a ser denominado de ensino fundamental, sendo facultativo o seu desdobramento em ciclos. Nos atuais Parâmetros Curriculares Nacionais (PCNs) para o ensino fundamental, encontra-se a seguinte divisão por ciclos - segundo BRASIL (1998c, p.127) -: primeiro ciclo: primeira e segunda séries, segundo ciclo: terceira e quarta séries, terceiro ciclo: quinta e sexta séries, quarto ciclo: sétima e oitava séries, contudo, a passagem do segundo para o terceiro ciclo é descrita como um momento de transição:

De um lado, o orgulho de estar crescendo e passando para o lado "dos grandes" (no caso de alunos entre onze/doze anos), e, de outro, um certo temor diante da substituição da convivência com um único professor pela interação com seis ou sete professores diferentes. Sem uma atenção especial a essas passagens, muitos alunos não conseguem dar conta das novas exigências e terminam por ser reprovados.

Entretanto, cabe salientar que a visão cognitivista, presente na Lei $\mathrm{N}^{\circ}$ 5.692/70, dá lugar a uma visão humanista na Lei $N^{\circ}$ 9.394/96, cuja preocupação relaciona-se com o "ser, com o fazer e com o conviver" (WEBER,1999). Nos atuais PCNs, também aparece esta reflexão, inspirada, segundo BITTENCOURT (1999), em paradigmas internacionais, principalmente, nos trabalhos do psicólogo espanhol Cesar Coll, cuja ênfase reside na aprendizagem e nas idéias de Piaget. Contudo, SADDI (1998) alerta para o fato de que, apesar da Lei 9.394/96 ter consolidado juridicamente as bases da educação nacional, com princípios de liberdade e ideário da educação como formação humana; no entanto, “(...) a retórica é velha, mas de carapuça nova. Os recursos nessa concepção são

\footnotetext{
${ }^{4}$ Entrevista da consultora pedagógica da editora Dom Bosco, Marli Maria Weber, à Rádio Central Brasileira de
Notícias (CBN), em 08-maio-1999.
} 
suficientes, a gerência é insuficiente; portanto o problema é de caráter administrativo" (p.50).

No âmbito deste contexto, na atual LDB, artigo 32, capítulo II, o ensino fundamental apresenta os seguintes objetivos:

I- o desenvolvimento da capacidade de aprender, tendo como meios básicos o pleno domínio da leitura, da escrita e do cálculo;

II- a compreensão do ambiente natural e social, do sistema político, da tecnologia, das artes e dos valores em que se fundamenta a sociedade; III- o desenvolvimento da capacidade de aprendizagem, tendo em vista a aquisição de conhecimentos e habilidades e a formação de atitudes e valores;

VI- o fortalecimento dos vínculos de família, dos laços de solidariedade humana e de tolerância recíproca em que se assenta a vida social. (BRASIL, 1998a, art.32).

Assim, na atual LDB, verifica-se que cabe às escolas a elaboração do projeto ou proposta pedagógica, na qual a totalidade da escola deverá participar, conforme sinaliza:

Cabe, portanto, à própria escola, em sua proposta pedagógica, definir suas necessidades e conveniências. Na verdade, é o coletivo da escola que vai definir todos os seus passos: objetivos, metas, recursos, critérios etc. Não se pode esquecer que a elaboração da proposta pedagógica será o exercício de autonomia da escola, que será maior à medida que aumentarem a participação e o envolvimento do coletivo de educadores da escola. (SÃO PAULO, 1998, p.4).

Neste contexto, de acordo com a LDB, a Educação Física deverá estar: “integrada à proposta pedagógica da escola" (BRASIL,1998b, cap. II, art.26), o que representa um desafio para este componente curricular que deverá realizar um trabalho efetivo e comprometido com a escola, caso queira cumprir o que determina a lei. 


\section{4 $O$ componente curricular educação física e o conhecimento escolar}

Para dimensionar a Educação Física, no interior da instituição escolar, MARIZ DE OLIVEIRA (1991, p.5) utilizou-se da metáfora dos "castelos de areia", explicando que:

A Educação Física estaria num destes castelos e todos esses castelos da Escola estariam interligados uns com os outros. Vejo então que a nossa Educação Física ou esse "castelo Educação Física" encontra-se nessa praia chamada Escola e que nós temos tentado e estamos procurando construí-lo arduamente. Um trabalho dificil, porque esse castelo não sendo sólido, não estando muito bem edificado, constantemente, tem sido destruído pelas águas com o subir da maré.

Diante destas considerações, cabe questionar sobre: o que ocorre com este componente para apresentar tais oscilações? Porque não estamos solidificados enquanto componente curricular? Será que nosso trabalho não tem sido realmente efetivo nas escolas? Para GHIRALDELLI JUNIOR (1992), desde o início dos anos oitenta, a Educação Física brasileira está em "ebulição", na busca de seu papel, valores e objetivos. Vários outros autores brasileiros também expressaram seus pensamentos em relação à identidade da área, como: CARMO (1982), MEDINA (1983), OLIVEIRA (1983), FERREIRA (1984), BETTI (1983,1991), CASTELLANI FILHO (1988), MARIZ DE OLIVEIRA (1991,1993), entre outros, além dos autores estrangeiros, tais como: MOSSTON \& MUELLER (1974), BRESSAN (1979), BROEKHOFF (1982), ELLIS (1988), NEWELL (1990) etc. Na década de 1980, a Educação Física passou por um período que se convencionou chamar de "crise" (SILVA, 1994). Este período, no entanto, possibilitou férteis discussões, reflexão e busca de identidade, no sentido 
de pensar caminhos, de acordo com FISCHMANN (1991, p.19), assinalando, desta forma, que a crise pode ter conotação positiva:

Um ponto importante neste pensar caminhos, é a busca da identidade, mesmo que isto pareça "vício psicologista". Identidade não se busca, se constrói, ela está sendo construída, e até um momento de crise é um momento de construção de identidade, sim. Estamos colocando uma auto-crítica, estamos nos olhando de maneira mais clara, mas precisamos estar sempre construindo.

A construção de uma identidade para a Educação Física passa por questões que vão desde o entendimento e significado do que seja tal disciplina, as relações da profissão com os aspectos acadêmicos e com a universidade, a compreensão do esporte, jogo, dança, lazer; bem como a Educação Física como fenômeno distinto e a qualidade da preparação profissional.

Ao mesmo tempo em que a área passou por crises internas, na década de 1970 e 1980, e impasses na década de 1990, acumulou também avanços (SADDI, 1998). Sobre a produção teórica em Educação Física, na década de 1980, buscamos dois autores que se debruçaram sobre o tema de forma crítica, e seus respectivos livros: OLIVEIRA (1994), "Consenso e conflito da educação física brasileira" e CAPARROZ (1997), "Entre a educação física na escola e a educaçâo fisica da escola".

Na apresentação do livro de OLIVEIRA (1994, p.13), escrita por Medina, já se encaminha a reflexão para o que representou a década de 1980 para a Educação Física: “embora com atraso em relação as outras áreas do conhecimento contemporâneo, a Educação Física brasileira passou por um verdadeiro renascimento nos anos 80 ". Nesse sentido, há o delineamento de duas perspectivas para a Educação Física: a do consenso e a do conflito. Como os próprios nomes induzem, o consenso estaria relacionado com a permanência, o 
conservadorismo da situação e o conflito com a mudança, denúncia do estabelecido. Os autores citados que adotaram linha de pensamento do conflito foram: CARMO (1982), MEDINA (1983), FERREIRA (1984), CAVALCANTI (1985), TAFFAREL (1985), BRACHT (1986), CASTELLANI FILHO (1988) e GHIRALDELLI JUNIOR. (1992).

No entanto, esse discurso de contestação, no qual o próprio Oliveira se inclui, trouxe instabilidade, no sentido de que parece ter sobrado um grande vazio, como se "tirassem o chão" da Educação Física escolar, negando a sua própria história. Porque não é possível utilizar os conhecimentos anteriormente produzidos, com o objetivo de ampliá-los e não de negá-los? Conforme entendimento de SOARES (1996, p.10):

Fazemos tábula rasa do que foi produzido ao longo de quase 200 anos. Não conseguimos acompanhar o movimento do pensamento e perceber como o conhecimento se amplia, se refaz pelo avanços da técnica, da ciência e pela inserção de diferentes práticas em diferentes culturas. Os clichês influenciam mais do que as inúmeras e inúmeras obras sobre Ginástica, sobre Jogo, Dança, e, sobretudo, Esportes. É agradável constatar que os anos 90 trouxeram um olhar mais abrangente aos estudos e pesquisas "sobre a Educação Física Escolar. Os reducionismos de natureza biológica, psicológica e social parecem não ter mais lugar no debate da área.

É nítido, tanto para CAPARROZ (1997), quanto para OLIVEIRA (1994), que a produção teórica, na década de 1980, na Educação Física sofreu forte influência do momento histórico no qual nosso país vivia, momento este que influenciou a educação como um todo, no período de redemocratização da sociedade, abertura política, ruptura e de contestação. CAPARROZ (1997) procura centrar sua pesquisa na produção teórica, na década de 1980, especificamente, no que foi produzido em Educação Física escolar nesse período. 
Segundo o referido autor, a crítica realizada nesse período passa por três eixos norteadores: a crítica à instituição militar, à médica e à esportiva na educação fisica escolar, com influências das teorias educacionais. Contudo, afirma que essas críticas ficaram mais no plano da denúncia, da Educação Física enquanto prática social, e o papel do professor de Educação Física como agente político. Pouco se questionou, no entanto, sobre o que seria a escola, currículo, componente curricular, especificidades da Educação Física escolar, ou seja, muitas das discussões levantadas neste período não se voltaram para a Educação Física dentro da escola, mas fora dela.

Pensar em "formar o ser humano integralmente" é um discurso que auxilia a manutenção do componente curricular Educação Física nas escolas, mas não é suficiente, é preciso que seus objetivos e conhecimentos estejam mais claros. Por exemplo, o Decreto $N^{\circ}$. 69.450, de 1971, considera a Educação Física como "atividade que por seus meios, processos e técnicas, desperta, desenvolve e aprimora forças físicas, morais, cívicas, psíquicas e sociais do educando" (BRASIL,1998b, p.21). A ênfase neste decreto centralizou-se na aptidão física e na iniciação esportiva que, a partir da quinta série, tornou-se um dos eixos fundamentais do ensino, com objetivos de descoberta de novos talentos que pudessem representar a pátria nas competições internacionais (BRASL, 1998b).

Entretanto, a escolha de objetivos educacionais claramente definidos não se trata de tarefa fácil. TANI (1991) questiona se, realmente, a Educação Física é capaz de assumir todos os objetivos a que se propõe, "será que a Educação Física tem condições de assumir que todos estes objetivos serão realmente alcançados? Será que não estamos estabelecendo "levianamente" os seus objetivos? Será que não estamos brincando de educação?” (p.65). Não é suficiente declarar como seus os objetivos que são de todos os outros 
componentes curriculares (CISNEIROS, 1995; TEIXEIRA,1993). Assim, a dúvida quanto aos objetivos e conhecimentos da Educação Física leva a dificuldades de se estabelecer o significado deste componente curricular. Preocupado com esta problemática, AGUIAR (1987) entrevistou vários alunos do antigo primeiro grau - e atual ensino fundamental - quanto ao significado da Educação Física para eles, e constatou, que não é claro o papel que tem a Educação Física escolar, faltando um trabalho de conscientização a respeito deste componente curricular. Contudo, REIS (1993) verifica que os próprios professores de Educação Física apresentam dificuldades em explicar a importância desse componente curricular.

Historicamente, a Educação Física tem ensinado o jogo, a ginástica, as lutas, a dança, os esportes; conteúdos clássicos e patrimônio que merecem ser tratados pela escola (SOARES, 1996). CASTELLANI FLHO (1995) analisa o que os profissionais da Educação Física reconhecem como sendo o conhecimento que deve ser ensinado nas escolas, e busca a raiz dessas controvérsias na própria preparação profissional deficiente, e a forte influência do paradigma da "aptidão física", que busca melhorar a condição física dos alunos. Segundo FERRAZ (1996), a Educação Física não pode deixar de veicular conhecimentos teóricopráticos, garantindo autonomia aos alunos para que, no futuro, eles possam atender às suas aspirações de lazer e adequar seus movimentos no cotidiano. BETTI (1992) entrevistou escolares de 10 a 15 anos de idade sobre as aulas de Educação Física e constatou que os alunos reclamaram da repetição dos conteúdos, sendo, basicamente, o conteúdo esportivo o predominante, e onde algumas modalidades são contempladas. No entanto, para VAGO $(1995$, p.21), a Educação Física sempre teve o que ensinar, afirmando que: 
De maneira geral, portanto, nunca faltou à Educação Física o que ensinar. Até porque se tivesse lhe faltado o que ensinar, certamente o seu destino seria a extinção! E se não foi extinta do currículo escolar, certamente, é porque dela sempre esperou-se que ensinasse algo.

Não podemos deixar de citar os esforços dos Seminários ocorridos na Escola de Educação Física e Esporte da Universidade de São Paulo, cujos temas foram: "Perspectivas da Educação Física Escolar para o Final da Década de 90" (1990), “Educação Física Escolar: Temos o que Ensinar?”(1993), "Educação Física Escolar: Conhecimento e Especificidade" (1995) e o último: "Educação Física e o Ensino Médio" (1997). A própria evolução temática desses seminários demonstrou a preocupação em responder às questões cruciais da Educação Física escolar, tais como o que temos para ensinar e qual o conhecimento e a especificidade deste componente curricular, de modo que SILVA $(1996$, p.32) identifica que:

Hoje já é admissível que no interior da escola, temos o que ensinar. (...) Já se admite que o conteúdo deste ensino vai além da mera execução da ginástica e dos esportes, assumindo as dimensões amplas de uma 'cultura corporal' (CASTELLANI FLLHO, 1995; SOARES, TAFFAREL, VARJAL, CASTELLANI FILHO, ESCOBAR \& BRACHT, 1992), 'cultura de movimentos' (BRACHT, 1989), 'cultura fisica' (BETTI, 1992); 'cultura corporal ou cultura física' (DAÓLIO, 1995) ou, ainda, de ‘patrimônio cultural e histórico’ (VAGO, 1995).

Os atuais PCNs da quinta à oitava séries merecem reflexão, neste contexto, uma vez que, apesar dos problemas políticos que margeiam o atual governo de Fernando Henrique Cardoso e das críticas apontadas, não podemos deixar de considerar os avanços em comparação aos PCNs da primeira à quarta séries do ensino fundamental. Assim, as críticas sinalizadas pelo Colégio Brasileiro de Ciências do Esporte (CBCE,1997) indicam a falta de um amplo 
debate, no qual participariam a sociedade civil. Tratam, também, da maneira como foram articulados os PCNs - de cima para baixo -, a redução das abordagens e superficialidade no tratamento dado aos posicionamentos filosóficos em Educação Física, a falta da presença da realidade brasileira e seus problemas socioculturais. Contudo, cabe salientar que apesar da política de "sucateamento" do ensino público no atual governo (SADDI, 1998), os PCNs da quinta à oitava séries apresentam, em sua elaboração, uma equipe formada por pessoas que representam a elite cultural educacional de nosso país, mesmo a análise dos nomes que fazem parte da consultoria são significativos. Portanto, consideramos relevante refletir sobre os conteúdos propostos da quinta à oitava séries em Educação Física que se encontram em tais PCNs, assim organizados:

Os conteúdos de aprendizagem serão apresentados dentro dos blocos, segundo sua categoria conceitual (fatos, princípios, e conceitos), procedimental (ligados ao fazer), e atitudinal (normas, valores e atitudes), o que permite a identificação mais precisa das intenções educativas. (...) Deve-se considerar que essas categorias de conteúdo (conceitual, procedimental, atitudinal) sempre estão associadas, mesmo que tratadas de maneira específica. (BRASL, 1998b, p.73).

Os conteúdos propostos nos PCNs da quinta à oitava séries do ensino fundamental em Educação Física estão organizados na perspectiva da cultura corporal de movimento, ou seja, os conteúdos da Educação Física apresentam-se como: "expressão de produções culturais, como conhecimentos historicamente acumulados e socialmente produzidos" (p.29). No entanto, cabe ressaltar que a utilização da perspectiva da cultura corporal de movimento não é nova, uma vez que podemos encontrá-la fortemente presente na década de 1980 como nos trabalhos de estudiosos da educação física, tais como: SOARES, TAFFAREL, VARJAL, CASTELLANI FILHO, ESCOBAR \& BRACHT (1992), сuјa 
composição e sistematização dos conteúdos encontram-se na perspectiva críticosuperadora. Nessa concepção, a Educação Física trata do conhecimento de uma área denominada de "cultura corporal", na qual entram o jogo, a dança, a ginástica, a luta, a acrobacia, a mímica, o esporte e outros, que fazem parte da história do homem e da cultura criada e construída pelo mesmo.

1) Os princípios norteadores que se encontram nos PCNs são: o princípio da inclusão, revertendo o próprio histórico da área de excluir os menos aptos para a inclusão dos alunos. Princípio da diversidade relativo à compreensão sobre o aluno em suas diversas dimensões: "afetivas, cognitivas, motoras e socioculturais" (p.19). O princípio da formação e informação plenas, citado por BETTI ${ }^{5}$ (1998), no qual são notórias as informações sobre a atividade fisica, principalmente as veiculadas pela mídia. Assim, a escola e o professor de Educação Física podem contribuir para que os alunos tenham conhecimentos sobre a atividade física a fim de que possam criticar e escolher atividades para o seu usufruto. A organização dos conteúdos, nesta concepção, apresenta-se em blocos, a saber: conteúdos atitudinais, e um segundo grupo composto por conteúdos conceituais e procedimentais, de maneira que:

Os conteúdos atitudinais (normas, valores e atitudes) são apresentados em primeiro plano, perpassando os três blocos, pois a aprendizagem de qualquer prática da cultura corporal de movimento que não considerálos de forma explícita se reduzirá a mera aprendizagem tecnicista e alienada. Entende-se por valores os princípios éticos e as idéias que permitem que se possa emitir um juízo sobre as condutas e seu sentido. As atitudes refletem a coerência entre o comportamento e o discurso do sujeito. São as formas que cada pessoa encontra para expressar seus valores e posicionar-se em diferentes contextos. As normas são

\footnotetext{
5 Palestra "Educação fisica: mercado de trabalho e preparação profissional", proferida por Mauro Betti na Semana da Educação Física da Universidade Cruzeiro do Sul (UNICSUL), em 31-out.-1998.
} 
padrões ou regras de comportamento construídos socialmente para organizar determinadas situações; constituem a forma pactuada de concretizar os valores compartilhados por um coletivo e indicam o que se pode e o que não se pode fazer. (...) Os conteúdos conceituais (conceitos e princípios) e procedimentais são distribuídos nas especificidades de cada bloco. Os procedimentos expressam-se em um saber-fazer que envolve tomar decisões e realizar uma série de ações, de forma ordenada e não aleatória, para atingir uma meta. Os conceitos e princípios constituem-se em generalizações, deduções, informações e sistematizações relativas ao ambiente sociocultural. São organizados lado a lado em função do diálogo que se estabelece na cultura corporal de movimento entre o fazer, o pensar e o sentir. (BRASIL, 1998b, p.73-4).

Na organização dos conteúdos apresentados nos PCNs da quinta à oitava séries do ensino fundamental, os conteúdos atitudinais perpassam os conceituais e procedimentais, os quais basicamente, encontram-se organizados em: conhecimento sobre o corpo, atividades rítmicas e expressivas, "esportes"que compreendemos como modalidades esportivas -, jogos, lutas e ginástica.

Consideramos um avanço a apresentação desses conteúdos nos PCNs, principalmente no que se refere à perspectiva dos conceitos e a preocupação em informar os alunos e não somente ligados ao fazer, à prática pela prática, como é característico da história da nossa área.

$\mathrm{Na}$ tentativa de buscar caminhos para o ensino da Educação Física escolar nas diferentes séries do ensino básico, De SANTO (1993, p.43) utiliza-se de um modelo adaptado de Tani para a sistematização do conhecimento em Educação Física escolar, enfatizando-se que:

O primeiro enfoque é a aprendizagem do movimento, a ser desenvolvida na pré-escola e nas primeiras séries do primeiro grau. Esta é uma fase já caracterizada como a mais importante para o desenvolvimento do potencial motor futuro da criança. Nas séries intermediárias do primeiro grau, dado que a criança já está em estágios 
mais maduros do desenvolvimento cognitivo, já é possível ao professor diminuir o peso dado à aprendizagem do movimento e se preocupar em estruturar as aulas para a aprendizagem sobre o movimento. (...) Nas duas últimas séries do primeiro grau os enfoques mais adequados são na aprendizagem sobre o movimento e na aprendizagem para 0 movimento.

As interações entre as aprendizagens do, através e sobre o movimento em Educação Física, segundo MANOEL \& DANTAS (1995), precisam considerar as capacidades metacognitivas em desenvolvimento na educação escolar, ou seja, a capacidade da criança em conhecer o conhecer. Para BETTI (1997, p.12), "precisamos ter claro que os alunos devem aprender algo na Educação Física, e, é claro, algo que ainda não saibam. (...) A Educação Física não se justifica na Escola se apenas propõe práticas ou conhecimentos que podem ser vivenciados e adquiridos em outros lugares". A preocupação com a aquisição de conhecimento nas aulas do componente curricular Educação Física encontra-se também nos trabalhos de LASTORIA, GIMENEZ \& SILVA (1997), nos quais há uma proposta para o conhecimento teórico a respeito do corpo e do seu controle, para o ensino fundamental. Nessa proposta, para o primeiro ciclo (primeira à terceira séries), os alunos devem ser capazes de conhecer como se compõe o corpo humano e alguns conceitos sobre função e importância dos componentes corporais, quando se está em movimento. Nas três séries seguintes (quarta, quinta e sexta séries), pretende-se um aprofundamento do conhecimento a respeito do corpo em movimento, quando o aluno deve ser capaz de descrever o movimento do próprio corpo, bem como de outros colegas. No último ciclo do ensino fundamental (sétima e oitava séries), o aluno deve identificar as implicações do movimento para o corpo e os efeitos da atividade física regular.

Nos trabalhos de FONTANA, TABORDA \& CANTOS (1997), também há preocupação com a aquisição de conceitos nas aulas de Educação 
Física, para além da prática de atividades físicas como único conteúdo, a sugestão para a Educação Física no ensino médio, é a utilização de textos como recurso didático-pedagógico, cujos temas estabelecidos pelos autores consistem em: atividade física e saúde, interesses físico-desportivos e o lazer, cultura corporal e seu desenvolvimento histórico-social e corporeidade. Entretanto, para PICCOLO (1995) da quinta à oitava séries as atividades esportivas aparecem como conteúdo mais específico desse nível de ensino, considerando-se os conceitos a partir da oitava série, fundamentados na corporeidade, ou seja, em vivências corporais. A referida autora enfatiza a constatação de que na escola as propostas curriculares possuem seqüencialidade, no entanto, na Educação Física, o mesmo não ocorre, podendo ser percebida em sua argumentação:

Em Educação Física isso não ocorre, pois o mesmo 'conteúdo', os mesmos 'procedimentos de ensino', os mesmos 'objetivos' propostos, são vivenciados por alunos de diferentes faixas etárias, de diferentes séries, de diferentes conhecimentos ou experiências nessa Disciplina currícular. Aí um pensamento imediato: ou a Educação Física, ou os demais componentes curriculares, ou ambos, estão inadequados no que diz respeito a essa estrutura pedagógica do processo de aprendizagem. (PICCOLO, 1995, p.24).

No âmbito da discussão sobre o componente curricular Educação Física, com o caráter de "atividade", "área de estudo", ou "disciplina", presentes nos trabalhos de vários estudiosos da área, tais como: CASTELLANI FILHO (1988), SOARES (1988), BRACHT (1989), MARIZ DE OLIVEIRA (1991), REIS (1993), CISNEIROS (1995) e FERRAZ (1996); observa-se uma busca do entendimento do que seja atividade, área de estudo e disciplina, uma vez que, nesses trabalhos, firma-se uma preocupação para que a Educação Física não seja somente uma atividade na escola. Entretanto, o grau de deturpação do entendimento do que sejam estas questões precisa ser melhor esclarecido, uma 
vez que, no parecer CFE (Conselho Federal de Educação) $N^{\circ}$ 853/1971, é enfatizado que o conhecimento deve estar presente desde a atividade, pois o ensino não ocorre no vazio, sem conexão com o conhecimento. Assim, nesse parecer, as atividades, áreas de estudo e disciplinas são entendidas como:

Na seqüência de atividades, áreas de estudo e disciplinas, parte-se do mais para o menos amplo e do menos para o mais especificado. Além disso, nas atividades, as aprendizagens desenvolver-se-ão antes sobre experiências colhidas em situações concretas do que pela apresentação sistemática dos conhecimentos; nas áreas de estudo, - formadas pela integração de conteúdo afins, consoante um atendimento que já é tradicional - as situações de experiência tenderão a equilibrar-se com os conhecimentos sistemáticos; e nas disciplinas, sem dúvida as mais específicas, as aprendizagens se farão predominantemente sobre conhecimentos sistemáticos. (SÃO PAULO, 1985, p.268).

A distinção que se estabelece neste parecer - citado anteriormente entre atividade, área de estudo e disciplina é de grau, ou seja "o conhecimento há de estar presente desde a atividade, sob pena de que o ensino a nada conduza, também não se dispensa alguma conexão com o real no estudo das disciplinas, sem o que se descambará para um intelectualismo vazio e inconsistente" (SÃO PAULO, 1985, p.268).

Neste instante, cabe inferir que mesmo tendo um caráter de atividade, segundo o parecer N. ${ }^{\circ}$ 853/1971, a Educação Física, enquanto um dos componentes curriculares da escola, não deve se dissociar do conhecimento, pois, como está na própria Lei, o ensino não ocorre no vazio. Assim, neste contexto, para MARIZ DE OLIVEIRA (1998), cabe à Educação Física escolar dar oportunidades à aprendizagem relacionada "a fatos, conceitos, princípios, procedimentos, valores, normas e atitudes, referentes aos conhecimentos (acumulados, sistematizados, organizados), sobre o movimento humano (relativo 
à motricidade)". Nessa percepção apresentada, o papel da Educação Física escolar estaria além da conotação da prática pela prática, mas possibilitaria que o individuo otimizasse suas potencialidades em busca de uma melhor qualidade de vida, sendo capaz de escolher, no futuro, as atividades motoras que desejar e também possuir condições de criticar.

\section{METODOLOGIA}

Este estudo, apresentou características exploratórias, identificativas e descritivas, com a utilização de procedimentos predominantemente qualitativos. Articulado com entrevistas e análise de conteúdo de bibliografia específica, foi desenvolvido com base nas orientações de KERLINGER (1980), LUDKE \& ANDRÉ (1986), MARTINS \& BICUDO (1989), RICHARDSON, PERES, CORREIA, PERES \& WANDERLEY (1989) e TRIVIÑOS (1987). Assim, para esta investigação procuramos o contexto natural e não situações experimentais controladas, buscando uma proximidade do cotidiano vivido.

Nesse entendimento, para levantar as informações e os dados para este estudo, ou seja, para selecionar a literatura pedagógica da Educação Física escolar, adotada pelos docentes da quinta à oitava séries, optamos pela realização de um recorte da realidade escolar, na tentativa de uma aproximação do universo, uma vez que não seria possível lidar com a sua totalidade. Assim, o processo adotado foi o da realização de entrevistas com professores da rede estadual de ensino, que atuam, planejam e organizam aulas de Educação Física para as referidas séries, ou seja, que estão inseridos nesta realidade.

A escolha e seleção das escolas pesquisadas deve-se ao fato de nos encontrarmos inserida na realidade de tais contextos a partir de trabalhos que já realizamos há algum tempo, cerca de cinco anos. Tais escolas pertencem à Oitava 
Delegacia de Ensino, atual Diretoria Regional de Ensino Leste IV. Nesta investigação, "o conhecimento não se reduz a um rol de dados isolados, conectados por uma teoria explicativa; o sujeito-observador é parte integrante do processo de conhecimento e interpreta os fenômenos, atribuindo-lhes um significado" (CHIZZOTTI, 1995, p.79).

Neste momento, cabe contextualizar as peculiaridades que compõem a Diretoria Regional de Ensino - Leste IV. Para tal tarefa, buscamos referências bibliográficas na referida Diretoria, particularmente, em seu acervo histórico, no setor denominado "Vida Escolar", no qual deveriam estar guardados os dados de todas as escolas que pertencem à mesma. Entretanto, não obtivemos êxito, pois constatamos que não há material escrito. Assim, optamos por buscar referências no Ministério de Educação e Cultura (MEC) e na Secretaria de Educação Fundamental (SEF), mas, também, não obtivemos resultados positivos. Sendo assim, optamos por entrevistar a atual Dirigente Regional de Ensino desta Diretoria, ou seja, Nereida Maria Núcci que há cinco anos, é dirigente da mesma. Para a entrevista, explicamos, inicialmente, os objetivos do trabalho. Assim, foram agendados, previamente, horário, data e $\operatorname{local}^{6}$. Em relação às questões, procuramos formulá-las, com antecedência. Contudo, durante a entrevista, surgiram outras questões, uma vez que a entrevista transcorreu de forma amigável e espontânea. Neste contexto, os dados obtidos sobre a Diretoria Regional de Ensino - Leste IV, a partir da referida entrevista, serão apresentados a seguir.

A Oitava Delegacia de Ensino foi criada por intermédio do Decreto ${ }^{\circ}$ 7.510 de 29/01/1976, instalada a princípio na Praça da Sé e, posteriormente,

\footnotetext{
${ }^{6}$ Esta entrevista foi realizada na Oitava Delegacia de Ensino, atual Diretoria Regional de Ensino Leste IV, em 06-abr.-1999.
} 
transferida, na década de 80, para o bairro de Penha de França. A partir do Decreto N..$^{\circ} 41.597$, de 19/02/97, sua sede passa para o bairro de Vila Matilde, onde encontra-se atualmente. Na cidade de São Paulo há 19 Delegacias de Ensino que agrupam as escolas por regiões. Entretanto, nem sempre esta regra é seguida, pois podemos encontrar Delegacias com número superior de escolas em relação às demais. Isto pode sugerir a existência de indicações políticas presentes. Atualmente, está sendo elaborado um estudo para melhor organizar e distribuir as escolas nas Delegacias. No que tange à Oitava Delegacia de Ensino, 49 escolas estaduais e 47 escolas particulares estão sob sua responsabilidade, perfazendo um total de 64.617 alunos. Cada Delegacia de Ensino apresenta suas peculiaridades conforme destacou a Dirigente da Oitava Delegacia de Ensino:

Cada Delegacia de Ensino é diferente uma da outra, cada uma tem um jeito, é igual uma escola, cada escola não tem sua "cara"? A Delegacia também. Então, têm Delegacias que você vai encontrar a Oficina Pedagógica junto dela - como a nossa -, a Oficina Pedagógica está aqui dentro. Então, fica difícil não dar atenção à parte pedagógica. Em outras Delegacias, a Oficina Pedagógica está distante da própria Delegacia, tornando-se um prédio mais voltado para o administrativo. A nossa tem um Núcleo Educacional de Informática que está entrando este ano, e é uma característica nova da nossa Delegacia. Há Delegacias com 26 escolas estaduais, outras com 70.

Em relação ao trabalho desenvolvido pela Oitava Delegacia, junto às escolas estaduais, pudemos perceber, inicialmente, que há materiais disponíveis. Por outro lado, existem falhas no intercâmbio com o professor em atuação. Observa-se que o fluxo de mudanças inicia-se no Ministério da Educação, que transfere a sua execução para as Secretarias Estaduais de Educação. Estas organizam reuniões com as Delegacias de Ensino, para, finalmente, implementálas nas escolas; entretanto, neste ponto surgem alguns entraves, conforme expressou a Dirigente entrevistada: 
Teve muitas mudanças durante cinco anos. Ocorreram mudanças, uma após a outra, agora, a gente vê que parou, é hora de consolidar todas essas ações do Ministério da Educação. Agora é hora do pai ir para a escola cobrar, participar, ajudar, valorizar a escola. Os professores receberam orientações. Nós precisamos disso, de caminhos, trabalhar com a capacitação dos professores. O HTPC (hora de trabalho pedagógico coletivo) precisa ser valorizado e não esvaziado; temos enviado material para as escolas, além de recursos humanos, enviamos circulares, trabalhamos com o professor coordenador de cada escola. Nós temos aqui, na Delegacia, na Oficina Pedagógica, várias produções boas para estar chegando aos professores. Mas aí, como estar cativando os professores, conquistando este espaço, é que é um nó.

Cabe, também, destacar que, após termos iniciado esta pesquisa junto à Oitava Delegacia de Ensino, ocorreram mudanças na reestruturação das mesmas. Isto é, a partir da Resolução da Secretaria da Educação de 08-jun.-1999, as Delegacias de Ensino passam para Diretorias Regionais de Ensino. Entretanto, não se trata apenas de uma mudança de nomenclatura. Isto porque, a partir da entrevista ${ }^{7}$ da Secretária Estadual da Educação, Teresa Roserley Neubauer da Silva, junto à Rádio Central Brasileira de Notícias (CBN), explicitou-se o caráter político desta medida, voltada, essencialmente, para a contenção de gastos. Isto se comprova à medida que foram extintas 50 Delegacias de Ensino no Estado de São Paulo; demitiram-se mais de 700 funcionários e muitos outros foram realocados. Desta forma, de um total de 19 Delegacias de Ensino existentes, na capital, foram criadas 13 Diretorias Regionais de Ensino. Com esta mudança, muitas Diretorias foram sobrecarregadas. Em relação à Delegacia de Ensino, escolhida no presente estudo, verificamos que a mesma não foi extinta; contudo o grupo de escolas sob sua responsabilidade ampliou-se de 49 para 75 . A Oitava Delegacia de Ensino,

\footnotetext{
${ }^{7}$ Entrevista realizada pela rádio Central Brasileira de Notícias (CBN), em 10-abr.-1999.
} 
então, torna-se Diretoria Regional de Ensino - Leste 4, cuja dirigente manteve-se, conforme Resolução da Secretaria da Educação de 07-jun-1999.

Para a realização deste estudo, optamos pela escolha de todas as escolas estaduais pertencentes à Oitava Delegacia de Ensino, atual Diretoria Regional de Ensino - Leste 4, que oferecem aulas da quinta à oitava séries do ensino fundamental. Junto à Oitava Delegacia, obtivemos informações sobre tais escolas. No entanto, uma das escolas selecionadas, situada no Jardim Marília, foi excluída deste estudo, uma vez que não foi possível entrevistar o professor de Educação Física que lá atua, pois, mesmo após várias tentativas, por intermédio de visitas, telefonemas e autorizações solicitadas, bem como o processo desgastante a que fomos submetidas, não obtivemos êxito. Dessa forma, foram, efetivamente, pesquisadas 26 escolas, cuja relação encontra-se no ANEXO I.

Cabe esclarecer, inicialmente, que, de acordo com dados de 15-set1999, encontravam-se atuando um total de 83 professores de Educação Física, nas referidas escolas selecionadas. Para compor a amostra de nossa pesquisa, selecionamos apenas um representante de cada escola, o que corresponde a $31,3 \%$ do universo dos professores. Esta escolha foi feita por julgarmos que se trata de um número adequado e representativo do recorte da realidade escolar efetuado. A seleção dos professores foi aleatória, tendo em vista o "cotidiano" das escolas públicas, ou seja, nem sempre os professores estão presentes na escola em virtude de: licenças médicas, faltas abonadas, faltas justificadas, faltas injustificadas, festas, campeonatos estudantis etc. Desta forma, optamos por entrevistar o professor de Educação Física que, no momento de nossa visita à escola, encontrava-se presente e atuando junto à quinta a oitava séries do ensino fundamental. 
Com o objetivo de contar com a colaboração dos diretores e professores, inicialmente, procuramos visitar as escolas e fornecemos as explicações necessárias sobre os objetivos deste estudo, garantindo a todos o sigilo quanto à identificação dos sujeitos que seriam entrevistados, ou seja, os professores de Educação Física. Cerca de nove entrevistas foram realizadas com professores que participavam de duas reuniões, ocorridas no primeiro semestre de 1999, na Oitava Delegacia, cujo tema foi o campeonato estudantil. Estas oportunidades possibilitaram uma economia de tempo bastante significativa, já que a área de abrangência da Oitava Delegacia é bastante extensa e compreende escolas situadas em bairros bastante distantes uns dos outros, tais como: Parque Savoy City, Cohab, Jardim Marília, Artur Alvim, Vila Ré, Vila Aricanduva, Jardim Maringá, Penha, Vila Granada, Vila Matilde entre outros.

Durante as entrevistas, foram seguidas as orientações de MARCHESINI DE PÁDUA (1996), tais como: marcar com antecedência o horário e o local da entrevista, explicar o objetivo do trabalho e o sigilo quanto à identidade do entrevistado, para que o mesmo não se sinta constrangido quanto ao seu conhecimento. Para maior segurança e fidelidade, as entrevistas foram gravadas e também anotadas. Quanto ao tipo de interação estabelecida com os entrevistados, merece ser ressaltado que, inicialmente, notamos que muitos professores mostravam-se receosos e inibidos. Percebemos, ainda, um certo temor e constrangimento em relação ao teor das perguntas. No entanto, quando nos identificamos também como professora de Educação Física, da mesma região, e, portanto, enfrentando a mesma gama de dificuldades, pudemos perceber que mudavam suas atitudes, adquirindo maior confiança para falar; o que, em muito casos, gerou, até mesmo, um prolongamento da entrevista além do esperado. A interação e a afetividade que foi se estabelecendo, ao longo das entrevistas, são 
outros aspectos que merecem consideração. Sendo oportuno destacar, ainda, que acabamos influenciando e incentivando os professores a voltar a estudar e, em muitos momentos, fomos questionadas, principalmente, sobre como é possível um professor da rede estadual de ensino fazer um curso de mestrado. Sentimo-nos, de certa forma, uma exceção. Isso pode ser percebido no discurso de um dos professores entrevistados:

O desemprego está grande, é preciso se garantir, é questão de sobrevivência. Você está fazendo mestrado, é 'mosca branca', é exceção entre os professores que estão atuando na rede estadual de ensino. É preciso ter um alicerce por trás, só estudar, está fora da nossa realidade. (...) Preciso de dinheiro, como largar um emprego que estou seguro, para poder estar estudando?

Percebemos que as dificuldades que os professores encontram para trabalhar, na rede estadual de ensino, repetem-se nas escolas, tais como: excesso de trabalho, classes lotadas, violência, sonhos em realizar cursos e a necessidade da educação continuada, entre outros problemas apontados. O ambiente de interação e respeito pelo entrevistado também foi um aspecto que consideramos. Nesse sentido, LUDKE \& ANDRÉ (1986, p.34-5) ressaltam que:

À medida que houver um clima de estímulo e de aceitação mútua, as infơrmações fluirão de maneira notável e autêntica. (...) Há uma série de exigências e de cuidados requeridos por qualquer tipo de entrevista. (...) Igualmente respeitado deve ser o universo próprio de quem fornece as informações, as opiniões, as impressões, enfim o material em que a pesquisa está interessada.

\footnotetext{
${ }^{8}$ Entrevista realizada em 19-mar.-1999, em uma reunião de educação física na Oitava Delegacia de Ensino.
} 
Para as entrevistas, procuramos elaborar uma questão central, a saber: "qual a literatura pedagógica em Educação Física que você tem mais consultado, atualmente, para o ensino das aulas da quinta à oitava séries do ensino fundamental? Segundo as orientações de RICHARDSON et al. (1989), em uma folha anotam-se os seguintes itens: o número da entrevista, data, lugar, idade do entrevistado e formação escolar que, posteriormente, irão compor as características sociodemográficas. A opção por uma questão central justifica-se por considerá-la suficiente para compor o leque da literatura pedagógica em Educação Física mais utilizada pelos professores que planejam e organizam aulas para estas séries de ensino. Outras informações também foram solicitadas, tais como: ano e instituição de ensino superior de graduação, carga horária semanal, tempo de atuação no magistério, cursos realizados e leitura e acesso aos PCNs. Em relação a essa última informação, justifica-se por considerá-la um referencial teórico relevante, não somente pela atualidade de seus conteúdos, mas, também, pelo avanço na sua apresentação, principalmente no que se refere à perspectiva dos conceitos e a preocupação em informar os alunos. Associado a isto, constatase, também, que as escolas estaduais têm acesso aos PCNs, via disquete, ou via MEC, ou mesmo por intermédio das Diretorias Regionais de Ensino. Cabe ressaltar, ainda, que outras questões surgiram durante as entrevistas, resultantes do próprio entrosamento com os professores.

Alguns dados relativos aos 26 professores entrevistados são apresentados: 
TABELA 1 - Distribuição do número de professores entrevistados segundo sexo e tempo de graduação.

\begin{tabular}{l|c|c|c|c|c|c}
\hline \multirow{1}{*}{$\begin{array}{c}\text { Tempo de } \\
\text { Graduação }\end{array}$} & \multicolumn{2}{|c|}{ Feminino } & \multicolumn{2}{c|}{ Masculino } & \multicolumn{2}{c}{ Total } \\
\cline { 2 - 7 } & $\mathrm{N}$ & $\%$ & $\mathrm{~N}$ & $\%$ & $\mathrm{~N}$ & $\%$ \\
\hline Até 5 anos & 1 & 3,8 & 0 & 0,0 & 1 & 3,8 \\
De 6 a 10 anos & 0 & 0,0 & 1 & 3,8 & 1 & 3,8 \\
De 11 a 15 anos & 5 & 19,2 & 4 & 15,3 & 9 & 34,6 \\
De 16 a 20 anos & 4 & 15,3 & 6 & 23,0 & 10 & 38,4 \\
Mais de 20 anos & 4 & 15,3 & 1 & 3,8 & 5 & 19,2 \\
\hline Total & 14 & 53,8 & 12 & 46,1 & 26 & 100,0 \\
\hline
\end{tabular}

Pudemos observar, a partir dos dados da TABELA 1, que dos 26 professores entrevistados, há um ligeiro predomínio do sexo feminino $(53,8 \%) \mathrm{em}$ relação ao masculino (46,1\%). Verificamos, também, que a maior parte dos profissionais $(57,6 \%)$ formou-se há mais de 15 anos e que, entre estes, há uma diminuta parcela de recém-formados (3,8\%). Por intermédio das entrevistas, foi possível notar que o tempo de graduação dos professores aproxima-se do tempo de atuação no magistério.

A relação das instituições de ensino superior de origem dos professores é apresentada na TABELA 2: 
TABELA 2 - Distribuição do número de professores entrevistados segundo a região da instituição de ensino superior de origem.

\begin{tabular}{l|c|c}
\hline \multicolumn{1}{c|}{ Região } & Número & $\%$ \\
\hline Interior & 5 & 19,2 \\
Grande São Paulo & 20 & 76,9 \\
Litoral & 1 & 3,8 \\
Capital & 0 & 0,0 \\
\hline Total & 26 & 100,0 \\
\hline
\end{tabular}

Os dados apontam que, da totalidade entrevistada, a grande maioria (76,9\%) são provenientes de instituições situadas na grande São Paulo, principalmente, dos municípios de Mogi das Cruzes e Guarulhos, situados próximos à região leste da capital. Talvez, seja possível afirmar, desta forma, que existe uma tendência ao ingresso em cursos universitários próximos à residência de origem, bem como a posterior inserção no mercado de trabalho na mesma região. Observamos, ainda, que, cerca de 19,2\%, são egressos de instituições do interior do estado. É importante, frisar, no entanto, que todos os entrevistados são procedentes de instituições particulares, o que pode estar associado ao nível sócioeconômico mais baixo observado na região.

$\mathrm{Na}$ TABELA 3, a seguir, podem ser acompanhados os dados relacionados à leitura dos PCNs pelos professores entrevistados. 
TABELA 3 - Distribuição do número de professores entrevistados segundo a leitura dos PCNs e tempo de graduação

\begin{tabular}{l|c|c|c|c|c|c}
\hline \multicolumn{1}{c|}{$\begin{array}{c}\text { Tempo de } \\
\text { Graduação }\end{array}$} & \multicolumn{2}{c|}{ Sim } & \multicolumn{2}{c|}{ Não } & \multicolumn{2}{c}{ Total } \\
\cline { 2 - 7 } & $\mathrm{N}$ & $\%$ & $\mathrm{~N}$ & $\%$ & $\mathrm{~N}$ & $\%$ \\
\hline Até 5 anos & 0 & 0,0 & 1 & 3,8 & 1 & 3,8 \\
De 6 a 10 anos & 0 & 0,0 & 1 & 3,8 & 1 & 3,8 \\
De 11 a 15 anos & 1 & 3,8 & 8 & 30,7 & 9 & 34,6 \\
De 16 a 20 anos & 2 & 7,6 & 8 & 30,7 & 10 & 38,4 \\
Mais de 20 anos & 0 & 0,0 & 5 & 19,2 & 5 & 19,2 \\
\hline Total & 3 & 11,5 & 23 & 88,4 & 26 & 100,0 \\
\hline
\end{tabular}

Os resultados, presentes na TABELA 3, mostram que a maioria $(88,4 \%)$ não leu os PCNs, independentemente, do tempo de graduação. Esperavase um maior interesse entre os mais jovens (recém-formados), porém nenhum deles afirmou ter lido os mesmos. Um número menor de entrevistados (apenas $11,5 \%)$ afirmou ter lido. Durante as entrevistas, foi possível verificar que apenas um profissional demonstrou conhecimento concreto a respeito do seu conteúdo. Foi possível chegar a esta questão, à medida que, no decorrer das entrevistas, observou-se que o conhecimento disponível resumia-se àquele proveniente da leitura do resumo contido na apostila da Associação dos Professores do Ensino Oficial do Estado de São Paulo (APEOESP), utilizada como base para o concurso para provimento de cargos efetivos para professores, realizado em 1998. Constatamos, também, que alguns dos professores tomaram contato com os mesmos, via reuniões de HTPC (hora de trabalho pedagógico coletivo), nas escolas em que atuam. Porém, isto pareceu incipiente. É preciso apontar, no 
entanto, a existência de dificuldades neste processo, explicitadas no discurso dos professores entrevistados ${ }^{9}$, a partir dos quais foi possível constatar que não se tratam apenas de dificuldades de acesso aos PCNs, mas, fundamentalmente, relativas à falta de preparo para compreender o seu conteúdo, e, principalmente, as condições $^{10}$ para a sua viabilização, como pudemos verificar em suas afirmações:

Tomei conhecimento dos PCNs pela apostila do concurso, não foi pela escola. Entretanto, pôr em prática é dificil, não tenho estrutura, nem bagagem e especialização para isso. As orientações deveriam partir da Delegacia de Ensino, entretanto é falho. Faltam projetos, deveriam mandar especialistas para as escolas. Pôr em prática é dificil, por exemplo, a questão dos temas transversais sobre a questão da sexualidade, não sei nem por onde começar.

Os PCNs são de difícil aplicação, pois como atuar com 50 alunos, num ambiente restrito? Trabalhar com os temas transversais, por exemplo, fica dificil, salas ambiente de educação física, não tem. Acho que os PCNs estão fora da realidade e o material que sugerem é de dificil aquisição, portanto não acrescentaram nada.

A análise das informações relacionadas ao número de professores que fazem uso de alguma referência bibliográfica para organizar e planejar aulas de Educação Física da quinta à oitava séries, na TABELA 4, apontou que, cerca de $73 \%$ dos entrevistados, afirmaram não utilizar qualquer referência bibliográfica como subsídio ao planejamento e elaboração das aulas. É preciso refletir que, de forma negativa, trata-se de um percentual bastante expressivo, ainda maior entre o grupo dos graduados há mais tempo. Tal fato deve ocorrer, provavelmente, tendo

\footnotetext{
${ }^{9}$ Entrevista realizada dia 06-08-1999, na Escola Estadual Hebraica.

${ }^{10}$ Entrevista realizada dia 30-07-1999, na Escola Estadual Profa. Maria Augusta de Ávila.
} 
em vista o desestímulo e a distância de um processo contínuo de atualização.

TABELA 4- Distribuição do número de professores entrevistados segundo a utilização de referência bibliográfica e tempo de graduação

\begin{tabular}{l|c|r|r|r|r|r}
\hline \multicolumn{1}{c|}{$\begin{array}{c}\text { Tempo de } \\
\text { Graduação }\end{array}$} & \multicolumn{2}{c|}{ Sim } & \multicolumn{2}{c|}{ Não } & \multicolumn{2}{c}{ Total } \\
\cline { 2 - 7 } & $\mathrm{N}$ & $\%$ & $\mathrm{~N}$ & $\%$ & $\mathrm{~N}$ & $\%$ \\
\hline Até 5 anos & 0 & 0,0 & 1 & 3,8 & 1 & 3,8 \\
De 6 a 10 anos & 1 & 3,8 & 0 & 0,0 & 1 & 3,8 \\
De 11 a 15 anos & 3 & 11,5 & 6 & 23,0 & 9 & 34,6 \\
De 16 a 20 anos & 3 & 11,5 & 7 & 26,9 & 10 & 38,4 \\
Mais de 20 anos & 0 & 0,0 & 5 & 19,2 & 5 & 19,2 \\
\hline Total & 7 & 26,9 & 19 & 73,0 & 26 & 100,0 \\
\hline
\end{tabular}

Verificamos que, cerca de $26,9 \%$ dos professores mencionaram a utilização de material bibliográfico de apoio, cujas obras estão relacionadas abaixo:

a) BRASLl. Secretaria de Educação Fundamental. Parâmetros curriculares nacionais: educação física da $5^{\mathrm{a}}$ à $8^{\mathrm{a}}$ séries do ensino fundamental. Brasília, MEC-SEF, 1998.

b) CONFEDERAÇÃO BRASILEIRA DE VOLEIBOL. Regras oficiais. Rio de Janeiro, 1998.

c) SILVA, J.B.F. Educação de corpo inteiro: teoria e prática da educação física. São Paulo, Scipione, 1995. 
d) TEIXEIRA, H.V. Aulas de educação física.. São Paulo, Ibrasa, 1978.

e) CONFEDERAÇÃO BRASILEIRA DE BASQUETEBOL. Regras oficiais. Rio de Janeiro, Sprint, 1998.

A obra relativa a Regras de Voleibol foi citada duas vezes, as demais foram citadas apenas uma vez. Cabe ressalvar, também, que foi mencionada, por um dos entrevistados, a utilização de um livro sobre drogas, no entanto, este foi excluído desta análise, uma vez que o professor não foi capaz de identificá-lo. As obras selecionadas foram tratadas a partir da técnica da análise de conteúdo, segundo as orientações de FRANCO (1986), RICHARDSON et al. (1989), CHIZZOTTI (1995), que consiste, segundo BARDIN (1979, p.42) em:

Um conjunto de técnicas de análise das comunicações visando obter, por procedimentos, sistemáticos e objetivos de descrição do conteúdo das mensagens, indicadores (quantitativos ou não) que permitam a inferência de conhecimentos relativos às condições de produçãorecepção (variáveis inferidas) destas mensagens.

ARENT (1998, p.39) considera que a análise de conteúdo representa um instrumento que podemos utilizar "para atender às necessidades da pesquisa. Seu valor e sua força advirão da soma dos recursos oferecidos pela técnica, da habilidade do pesquisador em utilizá-las e do substrato oferecido pelo referencial teórico". Na análise dos conteúdos, composta pelas fases de pré-análise, análise do material e tratamento dos resultados, a análise por categorias é uma das técnicas considerada mais antiga e utilizada a qual funciona: "por operações de desmembramento do texto em unidades, em categorias segundo reagrupamentos analógicos" (BARDIN, 1979, p.153). Nesse tipo de análise, considera-se como material de estudo qualquer forma de comunicação, tais como documentos escritos, livros, periódicos, jornais ou outras formas como radiodifusão, música e 
pintura. Na classificação por categorias, o texto é desdobrado e interpretam-se as expressões, frases e parágrafos (RICHARDSON et al., 1989).

Levando-se em consideração estas orientações, estabelecemos, previamente, as três categorias de análise, relacionadas aos tipos de conhecimento, ou seja, a) conceitos fatos e princípios (POZO, 1998), b) procedimentos (COLL \& VALLS, 1998) e c) atitudes, normas e valores (SARABIA, 1998).

\section{ANÁLISE DA BIBLIOGRAFIA}

\subsection{Educação de corpo inteiro: teoria e prática da educação física}

Na obra Educação de corpo inteiro: teoria e prática da Educação Física, escrita em 1989, por João Batista Freire da UNICAMP (Universidade Estadual de Campinas), em seu prefácio, o autor sinalizou o referencial teórico a ser utilizado em seu livro, que se baseia na obra de Piaget. Para o referido autor, a relação corpo e mente não devem ser compreendidos separados na escola. Conforme pode-se perceber em seus argumentos:

Corpo e mente devem ser entendidos como componentes que integram um único organismo. Ambos devem ter assento na escola, não um (a mente) para aprender e o outro (o corpo) para transportar, mas ambos para se emancipar. Por causa dessa concepção de que a escola só deve mobilizar a mente, o corpo fica reduzido a um estorvo que, quanto mais quieto estiver, menos atrapalhará. (...) Sugiro que, a cada início de ano letivo, por ocasião das matrículas, também o corpo das crianças seja matriculado. (FREIRE, 1997, p.13-4).

Entretanto, não discutindo o mérito desta obra, observamos que sua análise está voltada para o ensino da pré-escola à quarta série do ensino fundamental. Assim, não trata do ensino da quinta à oitava séries. Isso pode ser 
constatado a partir de uma própria afirmação do autor: "no caso deste livro, particularmente, voltado para a Educação Física da pré-escola à $4^{\star \prime}$ série do $1^{\circ}$ grau (...)" (p.209), observamos, portanto, que não faz parte do seu enfoque, o período compreendido entre pré-adolescência e adolescência. Nesse contexto, uma vez que os objetivos do presente estudo estão centrados da quinta à oitava séries, não consideramos significativa a contribuição desta obra para o presente trabalho. Portanto, não o selecionamos para análise, identificação e descrição em relação aos conteúdos de natureza conceitual, procedimental e atitudinal. No entanto, não podemos desconsiderar que nesta obra está inserida uma concepção de educação e de Educação Física voltadas para uma proposta construtivista, na qual o ser humano é visualizado como um indivíduo que constrói seu conhecimento, e que não está sendo negligenciado neste estudo.

\subsection{Regras oficiais de voleibol e regras oficiais de basquetebol}

Os livros "Regras oficiais de voleibol" e "Regras oficiais de basquetebol", ambos de 1998, esclarecem sobre como devem ser praticadas essas modalidades esportivas, segundo a Confederação Brasileira de Voleibol (CBV), Federação Internacional de Voleibol (FIVB), Confederação Brasileira de Basquetebol (CBB) e a Federação Internacional de Basquetebol (FIBA). Assim, as regras neles contidas sofrem alterações, passando por um processo de atualização, conforme as necessidades de evolução do próprio jogo. Foi possível detectar, a partir da análise dessas obras, que os conhecimentos conceitual, procedimental e atitudinal aparecem nos livros. Deste modo, o conhecimento conceitual diz respeito aos aspectos históricos e as características do jogo. $\mathrm{O}$ conhecimento procedimental trata do como jogar de acordo com as regras e o atitudinal pode ser percebido nas condutas do jogador frente ao adversário e no 
cumprimento das regras do jogo.

Entretanto, antes de iniciarmos a análise destes conhecimentos, cabe ressaltar que, para a análise, agrupamos estes livros por apresentarem um mesmo objetivo, ou seja, estes livros de regras não são específicos da Educação Física escolar, nem tratam da quinta à oitava séries. Neles, não há uma preocupação em se dimensionar a faixa etária para a prática dessas modalidades esportivas, tampouco há elementos que tratem da aplicação do jogo nas escolas. Assim, cabe ao professor de Educação Física fazer tal aplicação, bem como as devidas considerações ao se levar a modalidade esportiva voleibol e basquetebol para a escola.

Talvez resida aí uma das dificuldades, pois nesses livros são requeridas condições bastante distantes da realidade das escolas públicas estaduais, tais como: tamanho oficial da quadra, instalações, equipamentos, características da bola etc. Neste sentido, a exatidão no uso destas regras seria mais adequada aos clubes, onde há equipes de treinamento, cujos objetivos são outros, bem diferentes daqueles da escola. Contudo, por se tratar de livros que são consultados por professores de Educação Física, principalmente no que tange às alterações que ocorrem nas regras, resolvemos investigá-los.

Após essas considerações, passamos para a identificação dos conceitos, procedimentos e atitudes presentes nesses livros. Há um capítulo inicial, em ambos, que faz referência à história e às características das modalidades esportivas, tratando de um conhecimento conceitual. Pode-se verificar, assim, que o voleibol é antigo, criado em 1895, pelo americano William Morgan, em Massachusetts, nos Estados Unidos. É um esporte coletivo, no qual há duas equipes compostas por seis jogadores. Uma rede divide o campo ao meio e cada uma dessas equipes ocupa uma metade desse campo e o jogo tem o seguinte 
objetivo: "cada equipe envie a bola regularmente por cima da rede para a quadra oposta, cuidando para que a bola não caia no solo de sua própria quadra" (p.7). O basquetebol tem suas origens "nas mais diversas e antigas sociedades, porém na sua forma atual é conhecido desde 1981" (p.3), quando foi sistematizado pelo Professor James Naismith, em Springfield, Massachusetts, nos Estados Unidos. Assim como o voleibol, o basquetebol é considerado um esporte coletivo, jogado por duas equipes de cinco jogadores cada uma, com o objetivo de "jogar a bola dentro da cesta do adversário e evitar que a outra equipe se apodere dela ou faça pontos" (p.7).

Esses livros também apresentam algumas definições em seu conteúdo. No livro "Regras oficiais de voleibol", há a definição de rodízio (p.34), falta (p.38), saque (p.42), ataque (p.44), bloqueio (p.45) e conhecimento sobre a arbitragem. No livro de "Regras oficiais de basquetebol", há a definição de cesta (p.32), drible (p.36), zona de ataque (p.38), zona de defesa (p.38) e conhecimento sobre a arbitragem. No início desses livros, são enfatizadas as condições de instalação e equipamentos necessários para o jogo, tais como:

- Dimensões da quadra

- Superficie do jogo

- Linhas de delimitação da quadra

- Zonas e áreas do jogo

- Temperatura

- Iluminação

- Altura da rede

- Características da bola. (CONFEDERAÇÃO BRASILEIRA DE VOLEIBOL, 1998, p.16-7).

No que diz respeito ao conhecimento atitudinal encontrado, pudemos verificar que está presente nos direitos e responsabilidades básicas dos 
participantes, que regulam a forma de agir dos jogadores, principalmente, no que se refere à aceitação às regras determinadas. As faltas e penalidades são ações que ocorrem, à medida que as regras não são seguidas. Devem ser considerados os seguintes aspectos no voleibol e basquetebol, respectivamente:

- Os participantes devem conhecer e cumprir as Regras oficiais de voleibol.

- Os participantes devem aceitar as decisões dos árbitros com espírito esportivo, sem questioná-las. Em caso de dúvida, um esclarecimento pode ser solicitado somente por intermédio do capitão da equipe.

- Os participantes devem ter conduta respeitosa e cortês, dentro de um espírito esportivo, não somente para com os árbitros, mas, também, em relação aos demais componentes da equipe de arbitragem, adversários, companheiros da equipe e aos espectadores.

- Os participantes devem evitar ações ou atitudes que possam influenciar as decisões dos árbitros ou ainda encobrir faltas cometidas por sua equipe.

- Os participantes devem evitar ações que objetivem o retardamento do jogo.

- É permitida a comunicação entre qualquer membro da equipe durante o jogo. (CONFEDERAÇÃO BRASILEIRA DE VOLEIBOL, 1998, p.24).

- A conduta apropriada ao jogo exige a completa e leal cooperação entre os árbitros e seus assistentes e membros de ambas as equipes, incluindo-se técnicos, substitutos e acompanhantes.

- Ambas as equipes têm o direito de fazer seu melhor para assegurar a vitória, mas, isto deve ser feito dentro de um espírito desportivo e de lealdade.

- Qualquer infração repetida ou deliberada à esta cooperação ou ao espírito desta regra, será considerada falta técnica e penalizada, como previsto no (s) artigo (s) apropriado (s). BASQUETEBOL, 1998, p.46).

(CONFEDERAÇÃO BRASILEIRA DE

Quanto aos procedimentos, apresentam-se na maneira de saber jogar o voleibol e o basquetebol, nos aspectos técnico e táticos. Isto é, no voleibol, por exemplo, como realizar o saque, o toque, como executar o bloqueio de acordo com a determinação das regras etc. Assim, na constituição deste jogo, a linha de frente ou de ataque é formada por três jogadores que ocupam as posições: 4 
(esquerda), 3 (centro) e 2 (direita). Na linha de fundo, ou defesa, as posições: 5 (esquerda), 6 (centro) e 1 (direita). Desta maneira, o jogador número 1 inicia o saque e muda de posição, conforme estabeleceu a regra do chamado "rodízio", que consiste em:

Quando a equipe receptora do saque ganha o direito de sacar, seus jogadores efetuam o rodízio, avançando uma posição, sempre no sentido dos ponteiros do relógio (o jogador da posição 2 vai para a posição 1 para sacar, o jogador da posição 1 roda para a posição 6 e, assim, sucessivamente). (CONFEDERAÇÃO BRASILEIRA DE VOLEIBOL, 1998, p.34).

No entanto, cabe refletir que estes livros não fazem citação à Educação Física escolar, tampouco à escola, mesmo porque não é objetivo da Confederação Brasileira de Voleibol e da Confederação Brasileira de Basquetebol realizar tal enfoque. Contudo, não podemos negar que as modalidades esportivas voleibol e basquetebol fazem parte de nossa cultura, mas os mecanismos a serem adotados para a sua inserção na realidade escolar do país não são claramente tratados nestes livros. Portanto, cabe questionar: o que levar de conceitos, procedimentos e atitudes dessas modalidades esportivas para a quinta, sexta, sétima e oitava séries? Como adaptar as regras e as condições de instalações e equipamentos, presentes nestes livros à realidade das escolas públicas estaduais da cidade de São Paulo? Como dimensionar o fenômeno esporte e tudo o que envolve a sua prática, tais como, a competição, violência, "doping", treinamento e, às vezes, o excesso de treinamento, os patrocínios, mídia e os recursos financeiros? Associado a esses fatores, é preciso permitir ao aluno discutir, como espectadores e praticantes, a fim de que possam ter condições de criticar e também de participar com autonomia. Cabe, então, ao professor de Educação Física, ao fazer uso destes livros, elucidar essas questões junto aos alunos. 


\subsection{Parâmetros curriculares nacionais: educação física da $5^{a}$ à $8^{a}$ séries do ensino fundamental}

Os Parâmetros curriculares nacionais (PCNs) da quinta à oitava séries, cujo produto final de sua elaboração ocorreu em 1998, é um documento resultado de um trabalho no qual participaram vários educadores brasileiros. A necessidade de "construir referências nacionais comuns ao processo educativo em todas as regiões brasileiras" (BRASL, 1998c, p.5), é o que explica a contribuição deste trabalho, assim sinalizadas por Paulo Renato de Souza, atual Ministro da Educação e do Desporto:

Esperamos que os Parâmetros sirvam de apoio às discussões e ao desenvolvimento do projeto educativo de sua escola, à reflexão sobre a prática pedagógica, ao planejamento de suas aulas, à análise e seleção de materiais didáticos e de recursos tecnológicos e, em especial, que possam contribuir para sua formação e atualização profissional. (BRASIL, 1998c, p.5; grifos do autor).

Segundo a historiadora BITTENCOURT (1999), que participou da elaboração deste documento, os PCNs foram inspirados nos trabalhos do psicólogo espanhol Cesar Coll, cujo enfoque reside na aprendizagem e nas idéias de Jean Piaget. Nesses PCNs, especificamente em relação à Educação Física, encontramos a apresentação dos seguintes princípios: a) da inclusão, que trata de reverter o quadro de exclusão dos menos aptos para um processo de inclusão e b) da diversidade, que trata de diversificar a prática pedagógica da Educação Física, buscando ampliar o enfoque biológico para uma visão sociocultural; é uma tentativa de reverter "o quadro histórico da área de seleção entre indivíduos aptos e inaptos para as práticas corporais, resultante da valorização exacerbada do desempenho e da eficiência" (BRASIL, 1998b, p.19).

Inicialmente, este documento faz uma retrospectiva histórica das 
principais abordagens pedagógicas da Educação Física escolar, citando a abordagem psicomotora, a construtivista, a desenvolvimentista e as abordagens críticas. Enfatiza-se que os PCNs, da quinta à oitava séries em Educação Física, situam-se na perspectiva das abordagens críticas. Assim, compreende-se a Educação Física como "uma área que trata de um tipo de conhecimento, denominado cultura corporal de movimento" (p.26). Nesta visão, os conteúdos da Educação Física são analisados como: “expressão de produções culturais, como conhecimentos historicamente acumulados e socialmente transmitidos" (p.29). Sendo assim, os conteúdos propostos, nos PCNs, para as quatro últimas séries do ensino fundamental, encontram-se organizados na perspectiva da cultura corporal de movimento, de modo que a Educação Física é compreendida como:

(...) uma área de conhecimento da cultura corporal de movimento e a Educação Física escolar como uma disciplina que introduz e integra o aluno na cultura corporal de movimento, formando o cidadão que vai produzi-la e transformá-la, instrumentalizando-o para usufruir dos jogos, dos esportes, das danças, das lutas e das ginásticas em beneficio do exercício crítico da cidadania e da melhoria da qualidade de vida. (BRASIL, 1998b, p.29).

No referido documento também é ressaltada a idéia de que a Educação Física tem uma história relacionada à tradição e a um saber fazer ligado ao jogo, esporte, luta e à dança. No entanto, enfatiza que os objetivos da Educação Física escolar e os objetivos do esporte, dança, ginástica e luta são distintos. Assim, "embora sejam uma fonte de informações, não podem transformar-se em meta a ser almejada pela escola, como se fossem fins em si mesmos" (p.29). Neste contexto, apontam para uma prática da Educação Física escolar associada à informação e à crítica, principalmente, no que se refere aos conhecimentos no campo da cultura corporal, veiculados pela mídia. Nesse sentido, é considerada como tarefa da Educação Física escolar: 
(...) garantir o acesso dos alunos às práticas da cultura corporal, contribuir para a construção de um estilo pessoal de praticá-las, e oferecer instrumentos para que sejam capazes de apreciá-las criticamente (...). No âmbito da Educação Física, os conhecimentos construídos devem possibilitar a análise crítica dos valores sociais, como os padrões de beleza e saúde, desempenho, competição exacerbada, que se tornaram dominantes na sociedade, e do seu papel como instrumento de exclusão e discriminação social. A atuação dos meios de comunicação e da indústria de lazer em produzir, transmitir e impor esses valores, ao adotar o esporte espetáculo como produto de consumo, torna imprescindível a atuação da Educação Física escolar. Esta deve fornecer informações políticas, históricas e sociais que possibilitem a análise crítica da violência, dos interesses políticos e econômicos, do doping, dos sorteios e loterias, entre outros aspectos (BRASL, 1998b, p.30-1).

Outro aspecto a ser mencionado é a presença da Educação Física, assim como os demais componentes curriculares da escola, no trabalho com os denominados temas transversais, que consistem em temas de urgência para o país, tais como: ética, meio ambiente, orientação sexual, saúde, pluralidade cultural, trabalho e consumo. No entanto, cabe a seguinte reflexão: os professores estão preparados para esta tarefa? Em especial, os professores de Educação Física encontram-se preparados para trabalhar com estes temas? Como tornar eficaz o acesso e a ação pedagógica dos conhecimentos contidos nos PCNs nas escolas públicas estaduais?

Os PCNs apontam, também, para uma reflexão sobre o que ensinar, como ensinar e para quem ensinar, tendo como instrumento a abordagem dos conteúdos escolares em conceitos, procedimentos e atitudes. Assim, na organização dos conteúdos apresentados nos PCNs, os conteúdos de aprendizagem são apresentados dentro de blocos, segundo as categorias: “conceitual (fatos, princípios e conceitos), procedimental (ligados ao fazer) e 
atitudinal (normas valores e atitudes)" (p.73). Entretanto, ressalvou-se o fato de que essas categorias não se encontram separadas na aprendizagem, pois um conhecimento apresenta-se interligado ao outro.

Nesse entendimento, alguns critérios foram eleitos para a escolha dos conteúdos que serão desenvolvidos ao longo de todo o ensino fundamental, tais como: a relevância social, as características dos alunos e as especificidades do conhecimento da área. Assim, dentro dessa perspectiva, sugere-se a organização dos conteúdos em três blocos: 1) esportes, jogos, lutas e ginásticas; 2) atividades rítmicas e expressivas e 3 ) conhecimentos sobre o corpo. Alertando para o fato de que, não se tratam de estruturas estáticas ou inflexíveis, de modo que "o grau de aprofundamento dos conteúdos estará submetido às dinâmicas dos próprios grupos, evoluindo do mais simples e geral para o mais complexo e específico ao longo dos ciclos" (BRASL, 1998c, p.68). Ao considerar o jogo, o esporte, a ginástica, a luta, as atividades rítmicas e expressivas e o conhecimento sobre $o$ corpo como conteúdos da cultura corporal de movimento para a quinta à oitava séries, cabe refletir sobre que conceitos, fatos, atitudes, normas e valores deverão ser priorizados para este segmento escolar.

Foram considerados nos PCNs os conhecimentos sobre o corpo, abordando-se os conhecimentos anatômicos, fisiológicos, biomecânicos e bioquímicos, cujo objetivo é capacitar os alunos a criticar, julgar e escolher "atividades corporais saudáveis" (p.68). Entretanto, os conteúdos tratados no conhecimento sobre o corpo, assim como nos demais conteúdos propostos nos PCNs, repetem-se na quinta à oitava séries. Sugerindo-se que, no ciclo inicial, ou seja, na quinta e sexta séries, esses conhecimentos sejam tratados de maneira simplificada e ampliados e aprofundados no ciclo final, portanto, na sétima e oitava séries. Assim, destacou-se que: "nos ciclos finais do ensino fundamental, 
vão se consolidando possibilidades e necessidades de aprendizagem cada vez mais específicas, em função de as condições cognitivas, afetivas e motoras dos alunos permitirem" (...) (BRASIL, 1998c, p.86).

No entanto, como realizar a sistematização desses conhecimentos para a quinta, sexta, sétima e oitava séries? Verificamos que fica a critério do professor a realização desta tarefa, ou seja, sistematizar esses conhecimentos ao realizar a leitura dos PCNs, uma vez que esse documento somente sinaliza essa questão. Assim, não há um aprofundamento sobre os conhecimentos distribuídos nas diferentes séries, no entanto, não parece ser esse o objetivo deste documento, conforme pode-se constatar na afirmação: "o presente documento têm intuito de tornar viável ao professor e à escola operacionalizar e sistematizar os conteúdos da forma mais diversificada e articulada possível" (p.70). Nessa perspectiva, os conceitos e procedimentos referentes aos conhecimentos sobre o corpo são sugeridos como:

- Identificação das capacidades físicas básicas.

- Condicionamento físico e desenvolvimento das capacidades físicas.

- Identificação das funções orgânicas relacionadas à atividade motora.

- Conhecimento dos efeitos da atividade física sobre o organismo e a saúde.

- Planejamento do trabalho de condicionamento físico.

- Reconhecimento da aprendizagem motora.

- Reconhecimento da análise postural.

- Reconhecimento do corpo sensível e emotivo. (BRASL, 1998b, p.94).

São considerados, também, como conteúdo da cultura corporal de movimento, "os esportes, jogos, lutas e ginásticas", incluindo-se, nesse bloco, as informações "históricas sobre as origens e características dos esportes, jogos, lutas e ginásticas, e a valorização e apreciação dessas práticas" (p.71). Conforme analisado, anteriormente, este tema também encontra-se presente nas diversas 
séries do ensino fundamental. Nesta proposta, os conceitos e procedimentos relativos, segundo os autores, aos esportes, jogos, lutas e ginásticas apresentam-se mediante:

- Compreensão dos aspectos históricos sociais relacionados aos jogos, às lutas, aos esportes e às ginásticas.

- Participação em jogos, lutas e esportes, dentro do contexto escolar, de forma recreativa.

- Participação em jogos, lutas e esportes, dentro do contexto escolar, de forma competitiva.

- Vivência de jogos cooperativos.

- Desenvolvimento das capacidades físicas e habilidades motoras, por meio de práticas da cultura corporal de movimento.

- Compreensão e vivência dos aspectos relacionados à repetição e qualidade do movimento, na aprendizagem do gesto esportivo.

- Aquisição e aperfeiçoamento de habilidades específicas para jogos, esportes, lutas e ginásticas.

- Compreensão e vivência dos aspectos técnicos e táticos do esporte, no contexto escolar.

- Desenvolvimento da capacidade de adaptação de espaços e materiais, na criação de jogos.

- Desenvolvimento da capacidade de adaptação de espaços e materiais, para realizar esportes simultâneos, envolvendo diferentes objetivos de aprendizagem.

- Vivência de esportes individuais, dentro de contextos participativos e competitivos.

- Vivência de esportes coletivos, dentro de contextos participativos e competitivos.

- Vivência de variados papéis assumidos no contexto esportivo (goleiro, defesa, atacante, técnico, torcedor e juiz).

- Participação na organização de campeonatos, gincanas, excursões e acampamentos, dentro do contexto escolar.

- Compreensão das diferentes técnicas para ginástica, relacionadas a diferentes contextos histórico-culturais e com seus objetivos específicos.

- Compreensão e vivência dos aspectos de quantidade e qualidade, relacionados aos movimentos ginásticos. (BRASIL, 1998b, p.77).

Procurou-se dimensionar, também, neste documento, os conceitos 
relativos ao esporte, jogos, lutas e ginásticas. Entendendo-se o esporte como uma prática competitiva, que apresenta regras de caráter oficial, organizadas em federações e envolvendo condições especiais e equipamentos sofisticados. Os jogos, no entanto, possuem maior flexibilidade em suas regulamentações e caráter mais recreativo. As lutas, nesta concepção, são disputas, a partir de técnicas e estratégias, mediante regulamentação específica. Contudo, são consideradas lutas, desde as brincadeiras de cabo-de-guerra e braço de ferro, até as mais complexas relativas à prática de capoeira, judô e caratê. As ginásticas, referidas neste documento, são analisadas como técnicas de trabalho corporal, que podem ser realizadas de forma recreativa, competitiva e de convívio social.

Outro conteúdo presente nos PCNs são os conceitos e procedimentos relativos às atividades rítmicas e expressivas. Este bloco de conteúdos inclui manifestações da cultura corporal de movimento, considerando-se a diversidade das produções culturais da dança em nosso país. Assim, os conceitos e procedimentos relativos às atividades rítmicas e expressivas para a quinta à oitava séries são sugeridos como:

- Compreensão dos aspectos histórico-sociais das danças.

- Percepção do ritmo pessoal.

- Percepção do ritmo grupal.

- Desenvolvimento da noção de espaço, vinculada ao estímulo musical e ao silêncio, com relação a si mesmo e ao outro.

- Exploração de gestos e códigos de outros movimentos corporais, não abordados nos outros blocos.

- Compreensão do processo expressivo, partindo do código individual de cada um para o coletivo (mímicas individuais, representações de cenas do cotidiano em grupo, danças individuais, pequenos desenhos coreográficos em grupo).

- Percepção dos limites corporais, na vivência dos movimentos rítmicos e expressivos.

- Predisposição a superar seus próprios limites, nas vivências rítmicas e expressivas 
- Vivências das danças folclóricas e regionais, compreendendo seus contextos de manifestação (carnaval, escola de samba e seus integrantes, frevo, capoeira, bumba-meu-boi etc.).

- Vivência das manifestações das danças urbanas mais emergentes e compreensão do seu contexto originário.

- Vivência das danças populares regionais, nacionais e internacionais e compreensão do contexto sociocultural, onde se desenvolvem. (BRASIL, 1998b, p.77-8).

Estão, também, presentes neste documento, o conteúdo atitudinal que enfatiza a responsabilidade, cooperação, respeito, solidariedade, bem como atitudes que permitam refletir e criticar sobre a prática da cultura corporal de movimento, valorizando atitudes não discriminatórias quanto à habilidade e sexo. Permite, ainda, a inclusão de todos na prática da cultura corporal de movimento, valorizando-a como parte do patrimônio cultural da humanidade. Na perspectiva de formar um indivíduo autônomo para aprender, criticar e reivindicar, cuja aprendizagem possa ser significativa, permitindo aos alunos o acesso a informações da cultura corporal de movimento, não se restringe aos procedimentos, mas, também, possibilita a vivência de um amplo número possível de práticas.

Este documento sugere critérios de avaliação para os conteúdos selecionados e sistematizados em educação física, de modo que, os instrumentos levem em consideração a faixa etária, o grau de autonomia e discernimento dos alunos, incluindo, também, abordagens que permitam a participação dos alunos no processo de avaliação. Pretende-se, assim, avaliar se o aluno:

Realiza as atividades, agindo de maneira cooperativa, utilizando formas de expressão que favoreçam a integração grupal, adotando atitudes de respeito mútuo, dignidade e solidariedade. (...) Como o aluno se apropria de informações e experiências da cultura corporal de movimento, e de que modo estabelece relações entre esses 
conhecimentos no plano dos procedimentos, conceitos, atitudes, tendo em vista a promoção da saúde e a qualidade de vida (BRASIL, 1998b, p.102).

Não podemos deixar de refletir sobre os méritos deste documento, no que se refere à perspectiva dos conteúdos irem além dos procedimentos para uma abordagem de conceitos e atitudes, como conteúdos de ensino-aprendizagem. Talvez, o desafio maior resida no fato de que, a partir dos conhecimentos propostos nos mesmos, buscar-se sistematizar, organizar e aprofundar esses conhecimentos para uma contribuição efetiva para o ensino das quatro últimas séries do ensino fundamental.

\subsection{Aulas de educação física: $1^{\circ}$ grau}

Esta obra, escrita em 1978 por Hudson Ventura Teixeira, com a colaboração de Mário Carvalho Pini, tem como principal objetivo servir de orientação aos professores de Educação Física na elaboração de suas aulas, desde a primeira série até a oitava série do ensino fundamental. Assim, este livro propõe aulas-modelo, com o intuito de auxiliar o professor de Educação Física na sua ação pedagógica, afirmando que:

Esse plano mostra ao professor o caminho através do qual ele poderá conduzir com segurança seus alunos sem o perigo de possíveis desvios. São propostos aos professores aulas-modelo e uma coletânea de exercícios adequados às referidas séries, facilitando a elaboração dos planos de aula. São sugeridas também séries pedagógicas que muito poderão ajudar no planejamento das iniciações esportivas. Enfim, esse plano tem a intenção de auxiliar o professor no seu dia-a-dia e fazer com que o aluno no final da $8 .^{a}$ série esteja plenamente formado e consciente quanto ao valor das atividades físicas. (TEIXEIRA, 1978, p.30).

No entanto, esta obra, escrita na década de 1970, traz uma concepção 
de Educação Física calcada na aptidão física, ou seja, no aspecto biológico. Nessa época, a Educação Física escolar apoiava-se no princípio de formar indivíduos fortes e saudáveis para representar a pátria, idéia bastante recorrente no período em questão. Nesta visão, a Educação Física está voltada para o físico, cabendo à̀ outras disciplinas da escola, o trabalho intelectual; desta forma, "na escola, é que deveremos instalar um pequeno núcleo de iniciação educacional do físico, paralelamente à educação do intelecto" (p.16, grifo nosso). A Educação Física, portanto, era concebida como uma atividade ginástica, essencialmente prática, conforme pode-se perceber no trecho a seguir:

A educação física, ou atividade ginástica, apresenta-se como jogo ou trabalho. Corresponde a uma atividade muscular controlada, regida por normas e métodos, com objetivos bem definidos, desde 0 desenvolvimento morfofuncional do organismo jovem, até a manutenção do equilíbrio homeostático do indivíduo adulto e a readaptação orgânico-funcional do indivíduo doente ou com seqüelas traumáticas ou de doenças anteriores, colaborando decisivamente na educação do indivíduo. (TEIXEIRA, 1978, p.15).

A Educação Física escolar, para TEIXEIRA (1978), deve seguir o curso do desenvolvimento humano, respeitando-se as fases da aprendizagem. Neste sentido, para a fase escolar, compreendida entre sete aos 12 anos de idade, indicam-se atividades, tais como: jogos, ginástica, iniciação esportiva, corridas de 1000 a 2000 metros em bosques, salto em distância e arremessos. Dos 12 aos 14 anos de idade, sugere-se a ginástica, "com exercícios mais complexos" (p.20), trabalhos de resistência e de força e "iniciação esportiva especializada". Dos 14 aos 16 anos, nesta fase não há limites, segundo o autor, para a prática intensiva do esporte. Entretanto, a escolha da modalidade esportiva segue as tendências individuais e o biotipo do indivíduo.

Este livro divide-se nos seguintes tópicos: a) ciclo elementar - alunos 
da primeira à quarta séries e b) ciclo básico - alunos da quinta à oitava séries. Contudo, de acordo com os objetivos deste estudo, procuramos refletir sobre os planos de aula do referido livro, para a quinta à oitava séries. Assim, constatamos que, para este período escolar, a ênfase está nos conteúdos voltados para modalidades esportivas e a Educação Física escolar a serviço do esporte, conforme a seguinte afirmação: “(...) todas as vezes que tivermos chance de programar competições, deveremos incentivar os alunos a participarem dessas atividades que forjarão os futuros atletas, através da vivência esportiva de que tanto carece ainda nosso povo" (TEIXEIRA, 1978, p.31).

A organização dos planos de aula da quinta à oitava séries segue um mesmo padrão, estruturada em: 1) aquecimento, cuja duração gira em torno de cinco a 10 minutos, mediante marchas, corridas em diferentes ritmos, saltitamentos e jogos recreativos; 2) parte principal, com um tempo de 30 a 40 minutos, composta por duas partes a saber: a) formativa, “(...) destinada aos exercícios que contribuem para uma melhor formação corporal do organismo em fase de desenvolvimento, através da ginástica adequada às diferentes faixas etárias (...)" (p.33); b) esportiva, com a prática das diferentes modalidades esportivas e 3) parte final, composta por volta de cinco minutos, ora com exercícios de relaxamento, ora com exercícios respiratórios, jogos calmantes ou canto. A parte principal da aula, na qual se dedicam cerca de 40 minutos, é organizada por temporadas de modalidades esportivas assim constituída:

$\begin{array}{ll}1^{2} \text { Março-abril } & \text { Atletismo } \\ 2^{2} \text { Maio-junho } & \text { Atletismo e handebol } \\ 3^{2} \text { Agosto-setembro } & \text { Ginástica olímpica e basquetebol } \\ 4^{4} \text { Outubro-novembro } & \text { Ginástica olímpica e voleibol. (TEIXEIRA, } \\ \text { 1978, p.150) } & \end{array}$


A modalidade esportiva futebol, segundo o autor, é incluída na temporada esportiva complementar, ou seja, caso uma das temporadas seja prejudicada por fatores adversos, sugere-se como opção a temporada futebol. Entretanto, cabe salientar que essa organização do plano de ensino por temporadas é válida para a quinta à oitava séries. Segundo nosso entendimento sobre a leitura desta obra, é possível que os alunos não vivenciem a modalidade esportiva futebol, uma vez que detém um caráter optativo, daí o fato de ser considerada na temporada complementar, significando que, caso não ocorra uma das temporadas, então, recorre-se ao futebol. Da mesma forma, de março a novembro, segundo a organização das temporadas propostas pelo autor, a modalidade esportiva futebol não se faz presente. Assim, os alunos durante esses quatro anos de ensino e aprendizagem em Educação Física, terão a mesma gama de conteúdos, baseados, essencialmente, em práticas de modalidades esportivas. Tal observação remete à concepção de Educação Física escolar do autor, que a visualiza associada à prática de modalidades esportivas, que influencia na formação da personalidade do aluno, conforme pode ser constatado na seguinte passagem: "é ponto firmado, atualmente, que a Educação Física Escolar deve ser cada vez mais esportiva, conduzindo o aluno para a prática do esporte (...) (TEIXEIRA, 1978, p.34).

Nesse âmbito, o trabalho iniciado na quinta série, basicamente, constitui seqüências pedagógicas da aprendizagem de modalidades esportivas organizadas em temporadas. Para a sexta série "o trabalho que foi iniciado na $5^{\mathrm{a}}$ série deverá ser fixado na $6^{\mathrm{a}}$ série, para que o gosto pelo esporte seja dominante na preferência da criança (...)" (p.209). Na sétima série, “a preocupação do professor será a de aperfeiçoar a técnica dos fundamentos aprendidos nas séries anteriores e fixar as táticas e orientações (...)” (p.215). A partir da oitava série, há um aprofundamento 
do treinamento, de estudos táticos e de arbitragem, assim, ao final do ensino fundamental, segundo o autor, espera-se que:

$\mathrm{Na}$ oitava série devemos aproveitar para treinar todas as habilidades e técnicas fundamentais aprendidas e aperfeiçoadas. As técnicas e fundamentos que complementam esse ciclo deverão ser aprendidos para que os objetivos planejados para o primeiro grau sejam integralmente atingidos. Por se tratar da última série do ciclo, a revisão deverá ser feita criteriosamente para que o aluno esteja realmente apto para se desenvolver na fase seguinte. As correções técnicas e fundamentais devem ser feitas para coroarmos com êxito os objetivos propostos. (TEIXEIRA, 1978, p.220).

No que se refere ao processo de avaliação, presente neste livro, observamos que este pode ser identificado a partir de três itens, a saber: "a) avaliar conhecimentos, b) avaliar habilidades e c) avaliar atitudes" (p.32). No entanto, o conhecimento a ser analisado refere-se aos procedimentos sobre a aprendizagem de um saber-fazer, de acordo com as regras e fundamentos táticos das diferentes modalidades esportivas. Assim, não se faz presente, nesta obra, a preocupação com a aprendizagem de fatos, princípios e conceitos sistematizados, de modo que permitam ao aluno obter informações sobre as implicações do movimento humano, na sua vida, enquanto cidadão crítico e autônomo. A avaliação de atitudes é outro aspecto que merece consideração, uma vez que não apresenta um conteúdo explícito, não estando, portanto, claramente sistematizada nesta obra. Assim, há ênfase nos conteúdos procedimentais, sendo que os demais são tratados com superficialidade. Além da constatação da repetição de conteúdos, organizados em temporadas de modalidades esportivas, não podemos deixar de ressaltar, conforme já explicitamos no início da investigação da presente obra, que a mesma foi escrita em um determinado período histórico, relativo aos anos de 1970 e, portanto, circunscrita no processo de evolução no qual se 
encontrava a Educação Física escolar.

\section{CONSIDERAÇÕES FINAIS}

A análise das quatro obras, indicadas pelos professores de Educação Física, não pode ser desvinculada do momento histórico e dos objetivos que a mesma propõe. A partir da análise dessas obras, foi possível verificar que os conhecimentos de natureza conceitual, procedimental e atitudinal, estão presentes. No entanto, os PCNs para a Educação Física da quinta à oitava séries (BRASIL, 1998b) apontaram avanços, não somente pela atualidade de suas discussões, mas, também, pela preocupação em levar informações às aulas de Educação Física necessárias para que o aluno adquira uma visão crítica das práticas da cultura corporal de movimento; capacidade de reivindicar a sua implementação, junto às autoridades competentes, locais e autonomia na escolha das atividades que desejarem. Outro aspecto discutido nos PCNs consiste em considerar as atitudes como conteúdos, buscando contextualizá-las no processo de ensino e aprendizagem da Educação Física. Consideramos um desafio o ato de partir-se do conhecimento proposto nos PCNs, buscar aprofundar o que está aí contido e, então, organizar e sistematizar esses conhecimentos para a quinta, sexta, sétima e oitava séries. No entanto, esse trabalho precisa ter continuidade, ou seja, precisa ser discutido com os professores de Educação Física que estão atuando e que, muitas vezes, não compreendem, efetivamente, suas considerações, ou ainda, desconhecem a maneira de colocá-las em prática.

Essas considerações, presentes nos PCNs, confirmam as afirmações de De SANTO (1993), BETTI (1997) e de MARIZ DE OLIVEIRA (1998), que consideram que o papel da Educação Física escolar deve estar para além da prática, ou seja, sua conotação não seria apenas a de uma atividade no interior da 
escola, mas possibilitaria ao aluno a possibilidade de obtenção de conhecimentos sobre o movimento humano, mediante valores que possibilitam autonomia e crítica. Neste entendimento, MARIZ DE OLIVEIRA (1991, p.8) considera que, na Educação Física, não se estuda só o esporte, o jogo, a ginástica e a dança, mas o "significado e o entendimento do movimento em toda e qualquer atividade motora humana". No âmbito dessas discussões, a Educação Física escolar estaria de acordo com os demais componentes curriculares da escola, dentro de um contexto peculiar de ensino e aprendizagem, cujas características, de acordo com SANTOS (1994) e SAVIANI (1997), são: sistematização, organização curricular, seqüencialidade e intencionalidade; no qual este conhecimento, segundo CHERVEL (1990) e FORQUIN (1993), é recontextualizado e transformado até que chegue às escolas. Assim, nesse contexto, a Educação Física escolar, engajada nesse processo, passa a ter um compromisso maior com as questões que permeiam a escola, para que, segundo CAPARROZ (1997), a Educação Física esteja realmente integrada à escola e, não, simplesmente, desvinculada da mesma.

No entanto, na obra: Aulas de Educação Física: primeiro grau (TEIXEIRA, 1978), os conhecimentos de natureza atitudinal e conceitual são tratados com superficialidade, enfatizando-se os conteúdos procedimentais. Contudo, não podemos deixar de considerar que esta obra foi escrita na década de 1970 e, portanto, num determinado contexto histórico, que refletiu uma determinada ideologia em diversas áreas e, como não poderia deixar de acontecer, também na Educação Física escolar. Nesta obra, os conteúdos são, predominantemente, relativos à aprendizagem de modalidades esportivas, com repetições de conteúdos da quinta à oitava séries, confirmando os trabalhos de BETTI (1992), no qual os alunos reclamam da repetição de conteúdos nessas aulas e da ênfase no ensino centrado na aprendizagem de modalidades esportivas. 
Os livros de Regras de voleibol (CONFEDERAÇÃO BRASILEIRA DE VOLEIBOL, 1998) e Regras de basquetebol (CONFEDERAÇÃO BRASILEIRA DE BASQUETEBOL, 1998), não apresentam preocupação em discutir a modalidade esportiva voleibol e basquetebol no âmbito escolar. Não são, também, livros específicos da quinta à oitava séries, no entanto, são consultados por professores de Educação Física, em geral. Os conteúdos desses livros enfatizam a aprendizagem procedimental, estando mais próximos da realidade do esporte do que, propriamente, do contexto escolar. Cabe, portanto, aos professores de Educação Física, ao fazer a leitura dessas obras, realizar as devidas adaptações.

FREIRE (1999) e CORREIA (1999) identificam em seus trabalhos, desenvolvidos na perspectiva da análise de conteúdos de obras referentes às quatro séries iniciais do ensino fundamental e do ensino médio, respectivamente; que os tipos de conhecimento: conceitual, procedimental e atitudinal, estão presentes nas obras analisadas. No entanto, para os referidos autores, "esses conhecimentos identificados, nem sempre estavam diretamente relacionados com o movimento humano" (FREIRE, 1999, p.79). Constatam, também, a superficialidade no tratamento dado aos conhecimentos atitudinais e conceituais. Além disso, enfatizam que faltam estudos que tenham por objetivo identificar quais são os conceitos, princípios, fatos, valores, normas e atitudes específicos da Educação Física escolar. Nesse sentido, verificamos que falta um consenso sobre o papel da Educação Física no contexto escolar.

No que tange às entrevistas, apesar das limitações deste trabalho, algumas considerações merecem reflexão: a seleção de escolas pertencentes a uma Diretoria Regional de Ensino, o tempo diferenciado de atuação dos professores no magistério, suas formações acadêmicas diversificadas e seus níveis 
socioeconômicos que, certamente, influenciam na indicação da literatura pedagógica mais consultada por eles.

No entanto, foi possível realizar algumas inferências, por intermédio deste trabalho, tais como: a maioria dos professores entrevistados não utiliza qualquer referencial bibliográfico para o planejamento de suas aulas, baseando-se, apenas, em rotinas pessoais, com ênfase em conteúdos relacionados a modalidades esportivas, em decorrência de suas experiências docentes. Um fato que nos surpreendeu foi encontrar professores formados há pouco tempo, há cerca de um ano, os quais não fazem uso de qualquer referencial bibliográfico para planejarem e organizarem suas aulas, junto a essas séries. Apontam para deficiências na preparação profissional, fato que pouco contribui para a resolução de problemas pertinentes ao contexto escolar, enfatizando a aprendizagem de modalidades esportivas. Percebemos, também, as dificuldades que esses professores encontram ao buscar atualização de conhecimentos para a atuação docente, a partir de alguns relatos, como de um dos professores entrevistados: ${ }^{11}$

Na faculdade, você aprende uma coisa, a realidade é outra, você está na quadra, é outra realidade. Às vezes, a conversa com um colega te ajuda muito, te enriquece. $\mathrm{O}$ que conta mesmo é a sua experiência. Hoje, já tem muita coisa, hoje já tem livros de educação física, antigamente não tinha; mas livros 'certinhos' para seguir, não tem. Livros feitos diretamente para o professor de educação fisica, não tem.

Os problemas que os professores das escolas públicas estaduais enfrentam são amplos, complexos e merecem ser discutidos no âmbito da preparação profissional. Nesse sentido, os professores apontam para a falta de preparo para lidar com situações bastante adversas, como sinaliza um dos

\footnotetext{
${ }^{11}$ Entrevista realizada em 19-mar.-1999, na Escola Estadual Profa. Maria de Carvalho Senne.
} 
professores entrevistado"12: "o básico tem, como bola, espaço, interesse dos alunos; agora, o desrespeito, a violência, as drogas, o desrespeito da comunidade pela escola. (...) Como trabalhar com esta realidade? Não fomos preparados para isso". A frustração, diante desta realidade que se apresenta, é um sentimento que pudemos constatar no depoimento de vários professores, conforme pode ser verificado nos seguintes argumentos ${ }^{13}$ dos professores ${ }^{14}$ :

Os tempos mudaram, 'caiu' a esperança do professor. Antigamente, os alunos te respeitavam, vinham de uniforme. Agora, com a Lei do Menor, é uma tragédia, não há impunidade, só há direitos. A criação, o papel da família, ficou para a escola. As famílias estão desestruturadas, olha aí o desemprego. O que falta é impor limites aos jovens.

Às vezes, eu me pergunto sobre a violência que assola as escolas públicas e me deparo com classes de quinta série, na qual os alunos oscilam entre 15 a 19 anos de idade. (...) A linguagem desses alunos é desestimulante, é a linguagem da violência, da agressividade, é algo que me entristece e que me choca. Quando penso na faculdade, aí vem o conflito, pois não fui preparada para lidar com esta realidade tão distante da que eu aprendi na faculdade.

Cabe ressaltar, ainda, que, durante uma das entrevistas realizada em uma das escolas, foi ateado fogo na escola e, rapidamente, chamaram os bombeiros. Em uma outra escola, enquanto conversávamos com o professor, os alunos fumavam na quadra. Outra situação trazida ao nosso conhecimento, foi a necessidade de um professor entrevistado ter de "negociar" a quadra com os marginais da comunidade, para poder garantir seu espaço de aula. Conforme o

\footnotetext{
${ }^{12}$ Entrevista realizada em 30-jul.-1999, na Escola Estadual Deputado Astolfo Araújo.

${ }^{13}$ Entrevista realizada em 29-jul.-1999, na Escola Estadual Dom João Maria Ogno Osb.

${ }^{14}$ Entrevista realizada em 06-ago.-1999, na Escola Estadual Prof. Galileu Menon
} 
relato de um professor $^{15}$ :

Consegui, após vários anos, trabalhar em uma só escola, após 'rodar' várias escolas para cumprir a jornada. (...) Isto dificulta o trabalho e faz parte da realidade de vários professores. A realidade desta escola, que estou este ano, está melhor, pois não tenho que tirar 'bandido' da quadra, como na escola anterior em que trabalhei.

Devemos ressaltar, ainda, que as Diretorias Regionais de Ensino, são identificadas como um canal mediador entre a secretaria de educação e os docentes, por intermédio do qual os professores poderiam, por exemplo, ter a possibilidade de uma atualização. No entanto, muitos professores reclamaram do fato de que as reuniões de Educação Física, mediadas pelas Diretorias, são voltadas, basicamente, para a organização de campeonatos. Nesta perspectiva, pudemos constatar, pessoalmente, que das cinco reuniões das quais participamos, entre 1998 e 1999, todas foram direcionadas para a discussão de assuntos relativos ao campeonato escolar. Verificamos que, em uma das reuniões, levou-se mais de uma hora para decidir o posicionamento do número na camiseta do time (se seria na frente ou atrás), bem como o tipo de meia a ser utilizado (com ou sem listras). Cabe ressaltar, ainda, um dos desdobramentos desse trabalho de campo. Durante a entrevista com a Dirigente Regional de Ensino, Nereida Maria Núcci, aproveitamos a oportunidade para reivindicar reuniões que tratassem, especificamente, sobre o aspecto pedagógico da Educação Física, nas quais os PCNs pudessem ser discutidos. Fato interessante ocorreu, uma vez que fomos atendidas em nossa reivindicação. Marcou-se uma reunião, convocando os professores de Educação Física das escolas pertencentes à atual Diretoria Regional de Ensino Leste IV, direcionada para uma reflexão sobre os PCNs

\footnotetext{
${ }^{15}$ Entrevista realizada em 19-mar.-1999, na Escola Estadual Almirante Custódio José de Mello.
} 
relativos à área de Educação Física. Entretanto, esta reunião mostrou-se incipiente, pois não houve continuidade desta atividade, além do fato de ter sido convocado apenas um professor de Educação Física de cada escola e, ainda, constatada a ausência de muitos professores em decorrência de falhas no processo de convocação e comunicação. No entanto, a atitude pró-ativa da Dirigente Regional de Ensino, em atender nossa solicitação, pode ser compreendida a partir de sua visão positiva e a importância atribuída ao papel da Educação Física escolar, conforme relatou ${ }^{16}$ :

No ano passado, em 1998, tive o caso de um professor de educação física ameaçado de morte na escola. Eu fico pensando, desvirtuou tanto. Numa matéria que todo mundo deveria amar, está acontecendo isso? Por quê? Uma disciplina gostosa, por que está acontecendo isso? Aí você vê que há bons e maus profissionais. Mas o bom professor de educação física conquista tanto, que ele disciplina uma escola inteira, pelo respeito e brincando. Porque eles acham que aquela aula não é aula. Os alunos dizem: Você tem aula agora? Agora não, é educação física. Então para eles aula é sinônimo de coisa ruim, e educação física é sinônimo de coisa boa.

Outro desdobramento, surgido a partir deste trabalho, foi o convite da Diretoria Regional de Ensino, que fez parte deste estudo, para que realizássemos palestras para os professores de Educação Física pertencentes àquela Regional, tendo em vista o fato da quase inexistência de pessoas disponíveis na área para realizar tal tarefa. Além da reivindicação dos professores entrevistados, no sentido de aproximar a academia, ou seja, o conhecimento produzido nas universidades e a realidade do ensino público, considerando-se, também, a escassez de

\footnotetext{
${ }^{16}$ Esta entrevista foi realizada na Oitava Delegacia Regional de Ensino, atual Diretoria Regional de Ensino Leste IV em 06-abr.-1999.
} 
publicações pertinentes ao ensino da Educação Física no período escolar pesquisado.

Procuramos com este estudo, contribuir para a reflexão sobre a Educação Física da quinta à oitava séries do ensino fundamental. Sabemos que este é apenas um recorte de uma realidade que se apresenta num meio tão adverso, como é a realidade das escolas públicas estaduais da zona leste da cidade de São Paulo. No entanto, por acreditarmos na importância desse componente curricular, no que tange ao processo de educação de crianças e adolescentes, é que nos propusemos a verificar a presença, ou não, das categorias do conhecimento escolar na literatura pedagógica do componente curricular Educação Física, especificamente, da quinta à oitava séries. 


\section{REFERÊNCIAS BIBLIOGRÁFICAS}

ABREU, M.C.; MASETTO, M.T. O professor universitário em aula. São Paulo, M. G. Editores Associados, 1990.

AGULAR, J.S. Os significados da educação física no ensino de primeiro grau: depoimentos de professores e alunos. São Paulo, 1987. 200p. Dissertação (Mestrado) - Escola de Educação Física, Universidade de São Paulo.

APPLE, M.W. Ideologia e currículo. Trad. de Carlos E.F. de Carvalho. São Paulo, Brasiliense, 1982.

ARENT, M. Análise de conteúdo. Revista de Estudos, v.21, n.1, p.27-40, 1998.

BARDIN, L. Análise de conteúdo. Lisboa, Edições 70, 1979.

BELTRAME, S. Saber popular e saber escolar: realimentando a discussão. Contexto \& Educação, v.9, n.38, p.49-57, 1995.

BETTI, I.C.R. O prazer em aulas de educação física escolar: a perspectiva discente. Campinas, 1992. Dissertação (Mestrado) - Universidade Estadual de Campinas.

BETTI, M. Educação física: dessemelhança e identidade com o esporte e o jogo. APEF, v.6, p.10-12, v.7, p.9-10, 1983.

. Educação física escolar... de novo! APEF, v.11, p.11-12, 1997.

. Educação física e sociedade. São Paulo, Movimento, 1991.

BITTENCOURT, C.M.F. A globalização do currículo. In: Conferência: a reforma no currículo educacional no Brasil e no mundo, 05 de julho. São Paulo, Grupo GRUHBAS Projetos Educacionais, 1999. 
Propostas curriculares de história: continuidades e transformações. In: SÁ BARRETTO, E.S., org. Os currículos do ensino fundamental para as escolas brasileiras. São Paulo, Autores Associados, 1998. p.127-160.

BLANCO, R. Inovação e recursos educacionais na sala de aula. In: COLL, C., org. Desenvolvimento psicológico e educação: necessidades educativas especiais e aprendizagem escolar. Porto Alegre, Artes Médicas, 1995. v.3, p. 309-318.

BONETI, R.V.F. A legitimidade do ensino escolar. Contexto \& Educação, n.4, p.25-33, 1986.

BORGES, C.M.F. O professor de educação física e a construção do saber. Campinas, Papirus, 1998.

BRACHT, V. A criança que pratica esporte respeita as regras do jogo capitalista. Revista Brasileira de Ciências do esporte, n.2, p.62-68, 1986.

Educação física: a busca da autonomia pedagógica. Revista da Fundação de Esporte e Turismo, v.1, n.2, p.12-19, 1989.

BRANDÃO, C.R. O que é educação. São Paulo, Brasiliense, 1981.

BRASI, Leis etc. Lei No 9.394 Diretrizes e Bases da Educação Nacional. São Paulo, Editora do Brasil, 1998a. /Promulgada em 20 de dezembro de 1996/

BRASIL. MEC. Parâmetros curriculares nacionais: educação física da $5^{\mathrm{a}}$ a $8^{\mathrm{a}}$ séries do ensino fundamental. Brasília, MEC/SEF, 1998b.

Secretaria de Educação Fundamental. Parâmetros curriculares nacionais: introdução aos parâmetros da $5^{\mathrm{a}}$ a $8^{\mathrm{a}}$ séries do ensino fundamental. Brasília, MEC/SEF, 1998c.

BRESSAN, E.S. 2001: the profession is dead- was it murder or suicide? Quest, n.31, p.77-82, 1979.

BROEKHOFF, J. A discipline - who needs it? Proceedings National Association for Physical Education in Higher Education, v.3, p.28-35, 1982. 
CARMO, A.A. Educação física: crítica de uma formação acrítica. São Paulo, 1982. 184p. Dissertação (Mestrado) - Centro de Educação e Ciências Humanas, Universidade Federal de São Carlos.

CARRETERO, M.; CASCÓN, J.A. Desenvolvimento cognitivo e aprendizagem na adolescência. In: COLL, C., org. Desenvolvimento psicológico e educação: psicologia evolutiva. Porto Alegre, Artes médicas, 1995. v.1, p.273-287.

CASTELLANI FILHO, L. Considerações acerca do conhecimento (re)conhecido pela educação física escolar. Revista Paulista de Educação Física, p.10-17, 1995. Suplemento 1.

Educação física no Brasil: a história que não se conta. Campinas, Papirus, 1988.

CAPARROZ, F.E. Entre a educação física na escola e a educação física da escola. Vitória, UFES/Centro de Educação Física e Desportos, 1997.

CAVALCANTI, K.B. Tendência crítica e revolucionária da educação física. Sprint, p.25-32, 1985. n.especial.

CHAUÍ, M. Convite à filosofia. São Paulo, Ática, 1995.

CHERVEL, A. História das disciplinas escolares: reflexões sobre um campo de pesquisa. Teoria \& Educação, n.2, p.177-229, 1990.

CHIZZOTTI, A. Pesquisa em ciências humanas e sociais. São Paulo, Cortez, 1995.

CISNEIROS, M. Educação física escolar: temos o que ensinar? Revista Paulista de Educação Física, p.36-37, 1995. Suplemento 1.

COLÉGIO BRASLEIRO DE CIÊNCIAS DO ESPORTE. Educação Física escolar frente à LDB e aos PCNs: profissionais analisam renovações, modismos e interesses. Rio Grande do Sul, Ijuí- Sedigraf, 1997.

COLL, C. Psicologia e currículo. São Paulo, Ática, 1996. 
COLL, C.; VALLS, E. A aprendizagem e o ensino dos procedimentos. In: COLL, C., org. Os conteúdos na reforma. Porto Alegre, Artes Médicas, 1998. Cap.2, p.73-117.

COLL, C.; POZO, J.I.; SARABIA, B.; VALLS, E. Os conteúdos na reforma. Porto Alegre, Artes Médicas, 1998.

CONFEDERAÇÃO BRASLEIRA DE BASQUETEBOL. Regras oficiais de basquetebol. Rio de Janeiro, 1998.

CONFEDERAÇÃO BRASILEIRA DE VOLEIBOL. Regras oficiais de voleibol. Rio de Janeiro, 1998.

CORTELLA, M.S. Educação e cidadania: algumas heresias. Revista Paulista de Educação Física, p.4-6, 1995. Suplemento 1.

CORREIA, W.R. Educação física no ensino médio: discutindo a questão dos saberes escolares. São Paulo, 1999. 116p. Dissertação (Mestrado) - Escola de Educação Física e Esporte, Universidade de São Paulo.

CUNHA, C. Educação e autoritarismo no Estado Novo. São Paulo, Cortez, 1981.

De SANTO, D.L. Educação física: tendências e perspectivas. In: SEMANA DE EDUCAÇÃO FÍSICA,1., São Paulo, 1993. Anais. São Paulo, Universidade São Judas Tadeu, 1993. p.39-45.

DOMINIQUE, J. La culture scolaire comme objet historique. Paris, 1993.

ECHEITA, G.; MARTÍN, E. Interação social e aprendizagem. In: COLL, C., org. Desenvolvimento psicológico e educação: necessidades educativas especiais e aprendizagem escolar. Porto Alegre, Artes Médicas, 1995. v.3, p.38-48.

ELLIS, M.J. Warning: the pendulum has swung far enough. Journal of Physical Education and Recreation, n.59, p.75-78, 1988.

FERNANDES, A.V.M. Diretrizes curriculares nacionais para o ensino médio: é possível superar a histórica dualidade? Revista de Educação -APEOESP-, n. 10, p.21-28, 1999. 
FERRAZ, O.L. Educação fisica escolar: conhecimento e especificidade, a questão da pré-escola. Revista Paulista de Educação Física, p.16-22, 1996. Suplemento 2 .

FERREIRA, V.L.C. Prática de educação física no primeiro grau: modelo de reprodução ou perspectivas de transformação? São Paulo, Ibrasa, 1984.

FIERRO, A. Relações sociais na adolescência. In: COLL, C., org. Desenvolvimento psicológico e educação: psicologia evolutiva. Porto Alegre, Artes Médicas, 1995. v.1, p.299-303.

FISCHMANN, R. Realidade da educação física escolar. Revista Paulista de Educação Física, v.5, n.1/2, p.18-20, 1991.

FLORES, T.M.V. Para compreender o vínculo: educação popular x ensino escolar. Contexto \& Educação, v.1, n.4, p.34-38, 1986.

FONTANA, F.E.; TABORDA, M.A.; CANTOS, W. Proposição de um instrumento didático-pedagógico para a educação física no ensino médio. In: SEMINÁRIO DE EDUCAÇÃO FÍSICA ESCOLAR: educação física no ensino médio, 4., São Paulo, 1997.Anais. São Paulo, Escola de Educação Física e Esporte da Universidade de São Paulo, 1997. p.76.

FORQUIN, J.C. Escola e cultura: as bases sociais e epistemológicas do conhecimento escolar. Porto Alegre, Artes Médicas, 1993.

. Saberes escolares, imperativos didáticos e dinâmicas sociais. Teoria \& Educação, n.5, p.28-49, 1992.

FRANCO, M.L.P.B. O que é análise de conteúdo. EDUC, n.7, p.1-31, 1986.

FREIRE, E.S. Educação física e conhecimento escolar nos quatro anos iniciais do ensino fundamental. São Paulo, 1999. 90p. Dissertação (Mestrado) Escola de Educação Física e Esporte, Universidade de São Paulo.

FREIRE, J.B. Educação de corpo inteiro: teoria e prática da educação física. São Paulo, Scipione, 1997.

FREIRE, P. Educação e mudança. Rio de Janeiro, Paz e Terra, 1979. 
FURLAN, V.I. O estudo de textos teóricos. In: MARINGONI DE CARVALHO, M.C., org. Construindo o saber: metodologia científica - fundamentos e técnicas. Campinas, Papirus, 1997. p.119-128

GADOTTI, M. Pedagogia da práxis. São Paulo, Cortez, 1995.

GAGNÉ, R.M. Princípios essenciais. Porto Alegre, Globo, 1980.

GARCIA, F.L. Introdução crítica ao conhecimento. Campinas, Papirus, 1988.

GARDNER, H. Inteligências múltiplas: a teoria na prática. Porto Alegre, Artes Médica, 1995.

GHIRALDELLI JUNIOR, P. Educação física progressista: pedagogia crítico social dos conteúdos e a educação física brasileira. São Paulo, Loyola, 1992.

A globalização do currículo. In: Conferência: a reforma no currículo educacional no Brasil e no mundo, 05 de julho. São Paulo, grupo GRUHBASProjetos Educacionais, 1999.

GOODSON, I. La construción social del curriculum, possibilidades y ámbitos de investigación de la historia del curriculum. Revista de Educación, n.295, p.737, 1991.

HAMLTON, D. Sobre as origens dos termos classe e curriculum. Teoria \& Educação, n.6, p.33-52, 1992.

KERLINGER, F.N. Metodologia da pesquisa em ciências sociais. São Paulo, EPU/EDUSP, 1980.

LARA, T.C. A escola que não tive o professor que não fui. São Paulo, Cortez, 1996.

LASTORIA, D.C.; GIMENEZ, R.; SILVA, S.A.P.S. Conhecimento teórico a respeito do corpo e de seu controle: uma proposta para as aulas de educação fisica no ensino fundamental. In: SEMINÁRIO DE EDUCAÇÃO FÍSICA ESCOLAR: educação física no ensino médio, 4., São Paulo, 1997. Anais. São Paulo, Escola de Educação Física e Esporte da Universidade de São Paulo, 1997. p.73. 
LÉVY, P. As tecnologias da inteligência. Rio de Janeiro, Ed. 34, 1998.

LUCKESI, C.C. Filosofia da educação. São Paulo, EPU, 1990.

LUDKE, M.; ANDRÉ, M.E.D.A. Pesquisa em educação: abordagens qualitativas. São Paulo, EPU, 1986.

MACHADO, N.J. Ensaios transversais: cidadania e educação. São Paulo, Escrituras, 1997.

. Epistemologia e didática. São Paulo, Cortez, 1995.

MANOEL, E.J.; DANTAS, L.E.P.B.T. Conhecimento e educação física escolar. In: SEMINÁRIO DE EDUCAÇÃO FÍSICA ESCOLAR: conhecimento e especificidade, 3., São Paulo, 1997. Anais. São Paulo, Escola de Educação Física e Esporte da Universidade de São Paulo, 1995. p.32.

MARCHESI, A.; MARTÍN, E. Desenvolvimento metacognitivo e problemas de aprendizagem. In: COLL, C., org. Desenvolvimento psicológico e educação: necessidades educativas especiais e aprendizagem escolar. Porto Alegre, Artes Médicas, 1995. v.3, p.26-35.

MARCHESINI DE PÁDUA, E.M. Metodologia da pesquisa: abordagem teórico-prática. Campinas, Papirus, 1996.

MARIZ DE OLIVEIRA, J.G. Educação Física: entendimento do termo, São Paulo, 1998. [mimeografado].

Educação física: tendências e perspectivas. In: SEMANA DE EDUCAÇÃO FÍSICA, São Paulo, 1., São Paulo, 1993. Anais. São Paulo, Universidade São Judas Tadeu, 1993. p.6-22.

Educação física escolar: construindo castelos de areia. Revista Paulista de Educação Física, v.5, n.1/2, p.5-11, 1991.

MARTINS, J.; BICUDO, M.V. A pesquisa qualitativa em psicologia: fundamentos e recursos básicos. São Paulo, EDUC, 1989. 
MATALLO JUNIOR, H. A problemática do conhecimento. In: CARVALHO, M.C., org. Construindo o saber: metodologia científica fundamentos e técnicas. Campinas, Papirus, 1997. p.13-23.

MEDINA, J.P. Apresentação. In: OLIVEIRA, V.M. Consenso e conflito da educação física brasileira. Campinas, Papirus, 1994. p.3.

.A educação física cuida do corpo...e mente: bases para uma renovação e transformação da educação física. Campinas, Papirus, 1983.

MOREIRA, A.F. Currículo, cultura e sociedade. São Paulo, Cortez, 1994.

MOSSTON, M.; MUELLER, R. Mission, omission and submission in physical education. In: McGLYNN, G.H. Issues in physical education and sports, Palo Alto, National Press, 1974. p.97-106.

NEWELL, K.M. Physical education in higher education: chaos out of order. Quest, n.42, p.227-242, 1990.

NIDELCOFF, M.T. Uma escola para o povo. São Paulo, Brasiliense, 1978.

OLIVEIRA, V.M. Consenso e conflito da educação física brasileira. Campinas, Papirus, 1994.

O que é educação física. São Paulo, Brasiliense, 1983.

PALÁCIOS, J. Introdução à psicologia evolutiva: história, conceitos básicos e metodologia. In: COLL, C., org. Desenvolvimento psicológico e educação: psicologia evolutiva. Porto Alegre, Artes Médicas, 1995a. v.1, p.9-24.

. O que é a adolescência. In: COLL, C., org. Desenvolvimento psicológico e educação: psicologia evolutiva. Porto Alegre, Artes Médicas, 1995b. v.1, p.263-270.

PIATElli, G.; PALMARINI, M. Teorias da linguagem: teorias da aprendizagem. São Paulo, Cultrix, EDUSP, 1983.

PIAGET, J. Problemas de psicologia genética. Rio de Janeiro, Forense, 1973. 
PICCOLO, V.L.N. Educação física escolar: ser...ou não ter? Campinas, Editora da UNICAMP, 1995.

PILETTI, N. História da educação no Brasil. São Paulo, Ática, 1996.

POZO, J.I. A Aprendizagem e o ensino de fatos e conceitos. In: COLL, C., org. Os conteúdos na reforma. Porto Alegre, Artes Médicas, 1998. Cap.1, p.1770.

RANGEL, A.C.S. Aprender versus conhecer: do ir além do ser professor para ser educador matemático. Contexto \& Educação, v.5, n.18, p.75-91, 1990.

REIS, M.C.C. O entendimento da instituição escola apresentado por licenciandos em educação física e comparado ao de licenciandos em outros componentes curriculares, 1993. 94p. Dissertação (Mestrado)Escola de Educação Física, Universidade de São Paulo.

RESENDE, H.G.; SOARES, A. J.G. Conhecimento e especificidade da educação fisica escolar, na perspectiva da cultura corporal. Revista Paulista de Educação Física, p.49-59, 1996. Suplemento 2.

RICHARDSON, R.J.; PERES, J.A.S.; CORREIA, L.M.; PERES, M.H.M.; WANDERLEY, J.C.V. Pesquisa social: métodos e técnicas. São Paulo, Atlas, 1989.

ROMERO, J.F. Os atrasos maturativos e as dificuldades na aprendizagem. In: COLL, C., org. Desenvolvimento psicológico e educação: necessidades educativas especiais e aprendizagem escolar. Porto Alegre, Artes Médicas, 1995. v.3, p.74-81.

SADDI, R.S. Educação fisica e esportes: crises e desafios urgentes. Revista Unicsul, n.4, p.44-53, 1998.

SANTOS, L.L.C.P. O processo de produção do conhecimento escolar e a didática. In: MOREIRA, A.F.B., org. Conhecimento educacional e formação do professor. Campinas, Papirus, 1994.p.27-37.

SÃO PAULO (Estado). Secretaria da Educação. Educação física: legislação básica. São Paulo, SE, 1985. 
SÃO PAULO (Estado). Secretaria da Educação. Planejamento 1998: a escola de cara nova, as mudanças na educação e a construção da proposta pedagógica da escola. São Paulo, SE, 1998.

SARABIA, B, A aprendizagem e o ensino das atitudes. In: COLL, C., org. Os conteúdos na reforma. Porto Alegre, Artes Médicas, 1998. Cap.3, p.119177.

SAVIANI, D. Pedagogia histórico-crítica: primeiras aproximações. Campinas Autores Associados, 1997.

SAVIANI, N. Saber escolar, currículo e didática. São Paulo, Autores Associados, 1994.

SILVA, J.B.F. Educação de corpo inteiro: teoria e prática da educação fisica. São Paulo, Scipione, 1995.

SILVA, S.A.P.S. Consciência profissional de professores de educação física da Secretaria Municipal de Esportes Lazer e Recreação de São Paulo, 1991. 316p. Dissertação (Mestrado)- Pontificia Universidade Católica de São Paulo.

Educação física: um fenômeno que se desvela. Revista Paulista de Educação Física, v.8, n.1, p.58-68, 1994.

Educação fisica no primeiro grau: conhecimento e especificidade. Revista Paulista de Educação Física, p.29-35, 1996.Suplemento 2.

SNYDER, G. A alegria na escola. São Paulo, Manole, 1988.

SOARES, C.L Função da educação física escolar. Revista Paulista de Educação Física, p.6-12, 1996.Suplemento 2.

. Fundamentos da educação física escolar. Revista Brasileira de Ciências do Esporte, v.10, n.1, p.19-27, 1988.

SOARES, C.L.; TAFFAREL, C.N.Z.; VARJAL, E.; CASTELLANI FLLHO, L.; ESCOBAR, M.O.; BRACHT, V. Metodologia do ensino de educação física. São Paulo, Cortez, 1992. 
TAFFAREL, C.N.Z. A educação fisica na Nova República. Sprint, p.17-19, 1985. n.especial.

TANI, G. Perspectivas para a educação física escolar. Revista Paulista de Educação Física, v.5, n.1/2, p.61-69, 1991.

TAJRA, S.F. A escola na sociedade da informação. Ao mestre com carinho, v.2, n. 10, p.12, 1999.

TEIXEIRA, H.V. Aulas de educação física. São Paulo, Ibrasa, 1978.

TEIXEIRA, L.A. Estudo da motricidade humana como fonte de ordem para um tema científico, uma profissão, e um componente do currículo escolar. Revista Paulista de Educação Física, n.7, v.1, p.77-91, 1993.

TRIVIÑOS, A.N.S. Introdução à pesquisa em ciências sociais: a pesquisa qualitativa em educação. São Paulo, Atlas, 1987.

TUNG-SUN, C. A teoria do conhecimento de um filósofo chinês. In: CAMPOS, H., org. Ideograma: lógica, poesia, linguagem. São Paulo, Cultrix/EDUSP, 1977. p.27-37.

TYLER, R. Princípios básicos de currículo e ensino. Porto Alegre, Globo, 1976.

VAGO, T.M. Educação Física escolar: temos o que ensinar? Revista Paulista de Educação Física, p.20-26, 1995. Suplemento 1.

VYGOTSKY, L.S. A formação social da mente. São Paulo, Martins Fontes, 1994.

XAVIER, M.E. Capitalismo e escola no Brasil. Campinas, Papirus, 1990.

ZABALA, A. Aprendizaje significativo: el profesor como movilizador de las competencias de sus alumnos. In: SEMINÁRIO DE EDUCAÇÃO E SOCIEDADE, 6., São Paulo, 1997. Anais. São Paulo, Grupo Associação de Escolas Particulares, 1997. p.1-39. 
ANEXO I- Relação das 26 escolas estaduais selecionadas.

1- EEPG A HEBRAICA

2- EEPSG PROF ${ }^{a}$ ADELAIDE FERRAZ DE OLIVEIRA

3- EEPSG PROF ${ }^{\circ}$ AFONSO PENNA JUNIOR

4- EEPSG PADRE ANTÃO

5- EEPG PROF ${ }^{\circ}$ ANTONIO SYLVIO DA CUNHA BUENO

6- EEPSG DEPUTADO ASTOLFO ARAUJO,

7- EEPSG DOM CAMILO MARIA CAVALHEIRO,

8- EEPG ALMIRANTE CUSTÓDIO JOSÉ DE MELLO

9- EEPSG ESTHER FRANKEL SAMPAIO

10- EEPG GALILEU MENON

11- EEPSG INFANTE DOM HENRIQUE

12- EEPSG JAMIL PEDRO SAWAYA

13- EEPSG DOM JOÃO MARIA OGNO OSB

14- EEPSG JORGE DUPRAT FIGUEIREDO

15- EEPSG JOSÉ TALARICO

16- EEPSG JOZINEIDE PEREIRA GAUDINO

17- EEPG PROF ${ }^{\mathrm{a}}$ MARIA AP ${ }^{\mathrm{a}}$ DE CASTRO MASIERO

18- EEPSG PROF ${ }^{a}$ MARIA AUGUSTA DE ÁVILA

19- EEPSG PROF MARIA DE CARVALHO SENNE

20- EEPG PROF ${ }^{a}$ MARISA DE MELLO

21- EEPSG NOSSA SENHORA DA PENHA

22- EEPSG PROF ${ }^{\circ}$ OCTACILIO DE CARVALHO LOPES

23- EEPSG PROF ${ }^{\circ}$ ORESTES ROSOLIA

24- EEPSG DR. PAULO LAURO 
ANEXO I- Relação das 26 escolas estaduais selecionadas. (cont.).

25- EEPSG BARÃO RAMALHO

26- EEPSG DONA ZALINA ROLIM 